University of Windsor

Scholarship at UWindsor

$5-2016$

\title{
Lithospheric mantle xenoliths sampled by melts from upwelling asthenosphere: the Quaternary Tasse alkaline basalts of southeastern British Columbia, Canada
}

\author{
Ali Polat \\ University of Windsor \\ Eyal Friedman \\ University of Windsor \\ Derek J. Thorkelson \\ Simon Fraser University \\ Robert Frei \\ University of Copenhagen
}

Follow this and additional works at: https://scholar.uwindsor.ca/environmentalsciencepub

Part of the Geochemistry Commons

\section{Recommended Citation}

Polat, Ali; Friedman, Eyal; Thorkelson, Derek J.; and Frei, Robert. (2016). Lithospheric mantle xenoliths sampled by melts from upwelling asthenosphere: the Quaternary Tasse alkaline basalts of southeastern British Columbia, Canada. Lithospheric mantle xenoliths sampled by melts from upwelling asthenosphere: the Quaternary Tasse alkaline basalts of southeastern British Columbia, Canada, 33, 209-230.

https://scholar.uwindsor.ca/environmentalsciencepub/5

This Article is brought to you for free and open access by the Earth \& Environmental Sciences at Scholarship at UWindsor. It has been accepted for inclusion in Earth \& Environmental Sciences Publications by an authorized administrator of Scholarship at UWindsor. For more information, please contact scholarship@uwindsor.ca. 


\section{Lithospheric mantle xenoliths sampled by melts from} upwelling asthenosphere: the Quaternary Tasse alkaline

\section{basalts of southeastern British Columbia, Canada}

Eyal Friedman ${ }^{\mathrm{a}}$, Ali Polat ${ }^{\mathrm{a},{ }^{*}}$, Derek J. Thorkelson ${ }^{\mathrm{b}}$, Robert Frei $^{\mathrm{c}}$

${ }^{\mathrm{a}}$ Department of Earth and Environmental Sciences, University of Windsor,

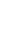

$$
\begin{gathered}
\text { Windsor, ON, Canada N9B 3P4 } \\
{ }^{\mathrm{b}} \text { Department of Earth Sciences, Simon Fraser University, Burnaby, BC, Canada } \\
\text { V5A 1S6 } \\
{ }^{\mathrm{c} D e p a r t m e n t ~ o f ~ G e o s c i e n c e ~ a n d ~ N a t u r a l ~ R e s o u r c e ~ M a n a g e m e n t, ~ U n i v e r s i t y ~ o f ~} \\
\text { Copenhagen, Geology Section, 1350 København K, Denmark }
\end{gathered}
$$

2

3

*Corresponding author: polat@uwindsor.ca 
The Tasse basalts are exposed near the north shore of Quesnel Lake in southeastern British Columbia. They host a variety of mantle xenoliths consisting predominantly of spinel lherzolite 26 with minor dunite and pyroxenite. Mineralogically, the xenoliths are composed of olivine, 27 orthopyroxene, clinopyroxene and spinel characterized by forsterite (Fo $87-93)$, enstatite $\left(\mathrm{En}_{90-92}\right)$, 28 diopside $\left(\mathrm{En}_{45-50}-\mathrm{Wo}_{40-45}-\mathrm{Fs}_{5}\right)$, and $\mathrm{Cr}$-spinel (6-11 wt. \% Cr), respectively. All of the mantle xenoliths are coarse-grained and show granoblastic textures. Clinopyroxene and spinel display textural evidence for chemical reactions with percolating melts.

The mantle xenoliths are characterized by restricted Mg-numbers (89-92\%) and low 32 abundances of incompatible elements $(\mathrm{Ba}=2-11 \mathrm{ppm} ; \mathrm{Sr}=3-31 \mathrm{ppm})$ and Yttrium $(1-3 \mathrm{ppm})$. 33 On the basis of REE patterns, the xenoliths are divided into three groups reflecting the various 34 degrees of mantle metasomatism: (1) Group 1 consists of concave-up LREE patterns $35\left(\mathrm{La} / \mathrm{Sm}_{\mathrm{cn}}=0.48-1.16 ; \mathrm{Gd} / \mathrm{Yb}_{\mathrm{cn}}=0.71-0.92\right) ;(2)$ Group 2 possesses flat to moderately LREEenriched patterns $\left(\mathrm{La} / \mathrm{Sm}_{\mathrm{cn}}=1.14-1.92 ; \mathrm{Gd} / \mathrm{Yb}_{\mathrm{cn}}=0.87-1.09\right)$; and (3) Group 3 is characterized by

37 strongly LREE-enriched patterns $\left(\mathrm{La} / \mathrm{Sm}_{\mathrm{cn}}=1.53-2.45 ; \mathrm{Gd} / \mathrm{Yb}_{\mathrm{cn}}=1.00-1.32\right)$. On MORB38 normalized trace element diagrams, the majority of the xenolith samples share the enrichment of 39 LILE (Rb, Ba, K), U, Th, Pb, Sr and the depletion of HFSE ( $\mathrm{Nb}, \mathrm{Ta}, \mathrm{Ti}, \mathrm{Y})$ relative to REE. 40 These geochemical characteristics are consistent with a compositionally heterogeneous sub41 continental lithospheric mantle source that originated as sub-arc mantle wedge peridotite at a 42 convergent plate margin.

The Tasse basalts have alkalic compositions characterized by low $\mathrm{SiO}_{2}(44-46$ wt.\%) and 44 high alkali $\left(\mathrm{Na}_{2} \mathrm{O}+\mathrm{K}_{2} \mathrm{O}=5.1-6.6\right.$ wt.\%) contents. They are strongly enriched in incompatible 45 elements $\left(\mathrm{TiO}_{2}=2.4-3.1\right.$ wt.\%; $\mathrm{Ba}=580-797$ ppm; $\left.\mathrm{Sr}=872-993 \mathrm{ppm}\right)$ and, display OIB-like trace 
46 element patterns $\left(\mathrm{La} / \mathrm{Sm}_{\mathrm{n}}=3.15-3.85 ; \mathrm{Gd} / \mathrm{Yb}_{\mathrm{n}}=3.42-4.61\right)$. They have positive $\varepsilon \mathrm{Nd}(+3.8$ to

$47+5.5$ ) values, with 338-426 Ma depleted mantle model ages, and display uniform OIB-like $\mathrm{Sr}$ $48 \quad\left({ }^{87} \mathrm{Sr} /{ }^{86} \mathrm{Sr}=0.703346-0.703591\right)$ and $\mathrm{Pb} \quad\left({ }^{206} \mathrm{~Pb} /{ }^{204} \mathrm{~Pb}=19.40-19.58 ;{ }^{207} \mathrm{~Pb} /{ }^{204} \mathrm{~Pb}=15.57-15.60\right.$;

$\left.49{ }^{208} \mathrm{~Pb} /{ }^{204} \mathrm{~Pb}=38.99-39.14\right)$ isotopic compositions. The basalts erupted discontinuously along a $50>1000 \mathrm{~km}$ long SE-NW-trending linear belt with minimal compositional variation indicative of a

51 homogenous mantle source. The $\mathrm{Sr}-\mathrm{Nd}-\mathrm{Pb}$ isotope and trace element systematics of the alkaline

52 basalts suggests that they originated from partial melting of an upwelling asthenospheric mantle

53 source. Melting of the asthenospheric mantle might have stemmed from extension of the 54 overlying lithosphere in response to the early stages of back-arc basin opening in the Omineca 55 and Intermontane belts. Ridge subduction beneath the Canadian Cordillera might have played an 56 important role in the weakening of the lithospheric mantle prior to its extension. Alternatively, 57 melting of the upwelling asthenosphere in response to the delamination of the lithospheric 58 mantle beneath the Rocky Mountain Trench might have generated the alkaline lavas.

60 Keywords: The Canadian Cordillera, Mantle xenolith, Alkaline basalt, Mantle metasomatism, 61 Continental lithospheric mantle

\section{1. Introduction}

The mantle has played a major role in the evolution of the Earth (Hofmann, 1997; Wang et 65 al., 2007; König et al., 2008). Since the mantle cannot be directly sampled, studies of mantle 66 xenoliths have provided significant insights into our understanding of the geodynamic and 67 petrological processes that shaped the evolution of the mantle-crust system (McCulloch, 1993; 68 McCulloch and Bennett, 1994; Hofmann, 1997; Kerrich et al., 1999; Condie, 2000; Downes, 
2001; Bennett, 2003; Arai et al., 2007; Chin et al., 2012). Samples recovered from kimberlites, lamproites and alkaline basalts have placed new constraints on the petrogenetic and geodynamic processes operating over the past 3.5 billion years (Shi et al., 1998; Wyman and Kerrich, 2010; Shirey and Richardson, 2011; Tang et al., 2013). These constraints have improved our understanding of plate tectonics, mantle plumes, and mantle composition (Ballhaus, 1993; Putirka, 1999; Beccaluva et al., 2004; Nkouandou and Temdjim, 2011; Shirey and Richardson, 2011) and provided insight into geodynamics, geochemistry, geophysics, and many other branches of Earth Sciences.

Mantle xenoliths hosted in alkaline basalts have been documented world-wide (Brearley et al., 1984; Parkinson et al., 2003; Ionov et al., 2006; De Hoog et al., 2010; Nkouandou and Temdjim, 2011; Tang et al., 2013; Downes et al., 2014). Alkaline basalts are lower in silica content than mid-ocean ridge basalts (MORB) and are characterised by high alkali content $\left(\mathrm{Na}_{2} \mathrm{O}+\mathrm{K}_{2} \mathrm{O}\right)$ (Polat et al., 1997; Nkouandou and Temdjim, 2011; Li et al., 2014). The origin of alkaline basalts can be explained by two main processes: (1) low degrees of partial melting of mantle (Kay and Gast, 1973; Wilshire et al., 1988); and (2) partial melting of enriched mantle (Wilshire et al, 1980; Wilshire et al., 1988; Maury et al., 1992; Polat et al., 1997). Enriched mantle may be produced by metasomatism involving hydrous and/or carbonate-rich fluids, intrusion of silicate magmas, or physical mixing between 'normal' mantle and fertile rocks such as pyroxenite and eclogite. These processes can raise the abundances of incompatible elements in the mantle which, in turn, can lead to greater alkalinity in derivative magmas (Bailey, 1972, 1982; Wilshire et al., 1988).

British Columbia, Canada, is known to host various locations of alkaline basalts within its complex geological history (Fig. 1) (Brearley and Scarfe, 1984; Brearley et al., 1984; Sun and 
92 Kerrich, 1995; Shi et al., 1998; Edwards and Russell, 2000; Peslier et al., 2000a, 2000b; Ferri

93 and O'Brien, 2002; Peslier et al., 2002; Abraham et al., 2005; Sluggett, 2008; Greenfield et al., 94 2013).

95 Several outstanding questions remain in regards to the evolution of the subcontinental 96 lithospheric mantle and relationship to subduction and orogenic processes beneath southeastern

97 British Columbia. How did the mantle evolve during the subduction and orogenic processes?

98 What are the origins of the Miocene to Holocene alkaline lavas that emplaced the mantle

99 xenoliths? Is there a relation between the evolution of the mantle and the origin of the alkaline

100 basalts? How did continental-scale tectonic processes play a role in the origin of alkaline basalts

101 and their mantle xenoliths? In this study, we present whole-rock major and trace element data for

102 twenty-two samples of mantle xenoliths and twenty-three samples of alkaline basalts collected 103 from the Tasse property of Barker Minerals Ltd, near Likely, British Columbia (Figs. 1 and 2). In

104 addition, we report whole-rock $\mathrm{Sr}-\mathrm{Nd}-\mathrm{Pb}$ isotope data for seven alkaline basalt samples. Using 105 the new and previously published data, we address the questions regarding the petrogenesis of 106 the mantle xenoliths and their host alkaline basalts with respect to the subcontinental lithospheric 107 and asthenospheric mantle domains beneath southeastern British Columbia.

\section{Regional geology}

The Canadian Cordillera consists of rocks that range in age from Paleoproterozoic to

111 Holocene. They are commonly divided into assemblages that originated along the western 112 margin of ancestral North America (cratonic), near North America (pericratonic) or far from 113 North America (exotic) (Gabrielse et al., 1991; Nelson and Colpron, 2007). In the Mesozoic, 114 these assemblages were brought together by subduction, forming a collage of accreted terranes 
115 (tectonic blocks) and deformed cratonic and pericratonic rocks (Coney et al., 1980; Monger et 116 al., 1982; Gabrielse et al., 1991; Johnston, 2001). These events led to westward growth of the

117 North American continent and the formation of a new western margin near to that of the present 118 day coastline. By the Cenozoic, most of the accretionary tectonism was complete but the 119 Cordillera continued to undergo deformation, metamorphism and magmatism. During the 120 Paleocene and Eocene, two or three oceanic plates were subducting beneath the continental 121 margin, leading to widespread magmatism, strike-slip deformation, localized extension and core122 complex formation (Ewing, 1980; Parrish et al. 1988). During this time, magmatism was 123 voluminous and subduction processes were modified by the effects of ridge subduction and slab 124 window formation (Breitsprecher et al., 2003; Madsen et al., 2006). Offshore plate 125 reorganization in the mid-Cenozoic led relative quiescence in the Oligocene and restriction of arc 126 magmatism to the northern and southern parts of the Canadian Cordillera (Madsen et al., 2006). 127 The sum of all of the aforementioned activity led to the recognition of five morphogeologic belts 128 which are characterized by a combination of features including terrane type and origin, age, 129 metamorphic grade and geomorphology (Gabrielse et al., 1991; Monger, 2014). During the 130 Miocene to Holocene, magmatic activity was widespread throughout the region, and was 131 grouped by Bevier et al. (1979) into three main regions: the Cascade-Garibaldi arc in the 132 southwest, the Aleutian-Wrangell volcanic belt in the northwest, and a broad intervening region 133 of varied but largely mafic alkaline volcanism. This intervening volcanic field was regarded 134 having a range of causes including back-arc volcanism (Chilcotin Group) and mantle plume 135 activity (Anahim belt) (Fig. 1) (Bevier et al., 1979; Kuehn et al., 2015). Edwards and Russell 136 (2000) re-examined the northern part of this mafic field, named it the Northern Cordilleran 
137 Volcanic Province (NCVP) (Fig. 1), and suggested that lithospheric extension played a primary 138 role in its development.

Using a different approach, Thorkelson and Taylor (1989) and Thorkelson et al. (2011) regarded the Chilcotin-Anahim-NCVP field as having a common origin related to subduction of

141 the Juan de Fuca spreading ridge and formation of an extensive slab window in the Late 142 Cenozoic. In this model, the entire region between the Garibaldi and Wrangell arcs was affected 143 by upflow of asthenospheric mantle through the slab window, leading to low-degree partial melts 144 of mantle peridotite. According to the interpretations of Edwards and Russell (2000), Greenfield 145 et al. (2013) and Francis et al. (2010), both asthenospheric and lithospheric mantle were involved 146 in the mantle anatexis. As noted by Edwards and Russell (2000), Francis et al. (2010) and 147 Thorkelson et al. (2011), the previously identified processes of back-arc circulation (developed 148 more fully by Currie and Hyndman, 2006), plume activity and lithospheric extension may have 149 contributed locally to the various volcanic belts included within the field of slab window 150 magmatism. In addition, general westward mantle flow and continental lithospheric delamination 151 may have contributed to the magmatic activity (Boa et al., 2014). Importantly, these processes 152 contributed to the current thermal (hot) and rheological (weak) state of the central and western 153 Cordillera (Hyndman et al., 2009), in which a thin layer of lithospheric mantle underlies a hot 154 crust with high heat flow and a Moho temperature near $800{ }^{\circ} \mathrm{C}$ (Harder and Russell, 2006; 155 Francis et al., 2010; Greenfield et al., 2013). Thinning of the mantle lithosphere is likely to be 156 ongoing (Francis et al., 2010). 


\section{Geology of the study area}

The study area is located within the Cariboo district, which lies within the southern portion of the Omineca belt (Supplementary Fig. 1) (Monger and Price, 2002). The region consists of various terranes including the Cariboo, Quesnel, Cache Creek and Kootenay terranes (Fig. 2) (Ferri and Schiarizza, 2006; Eyles and Miall, 2007). The Cariboo terrane has been identified as a representative piece of the ancestral North American margin. This portion of the terrane contains carbonate and siliciclastic rocks (Struik, 1986; Ferri and Schiarizza, 2006).

The Barkerville subterrane, of the larger Kootenay terrane, is bounded on both sides by thrust faults (Fig. 2) (Struik, 1986; Ferri and Schiarizza, 2006). To the west of the Barkerville subterrane is the Eureka thrust fault that separates the Barkerville subterrane from the Quesnel terrane (Fig. 2). The Pundata thrust and Pleasant Valley thrust separate the Cariboo terrane from the eastern edge of the Barkerville subterrane (Fig. 2) (Struik 1986; Ferri and Schiarizza, 2006).

The Quesnel terrane consists principally of arc volcanic and sedimentary rocks. This terrane has been thrust onto the hanging wall of the Eureka thrust and Crooked amphibolite of the Slide Mountain terrane (Fig. 2) (Ferri and Schiarizza, 2006). The sedimentary rocks are of the Nicola Group and characterized by phyllitic rocks with interbeds of siltstones to fine-grained sandstone. Minor mafic tuffaceous and coarse-grained volcaniclastic rocks have been found to interfinger in the Nicola Group (Ferri and O'Brien, 2002; Ferri and Schiarizza, 2006; Thomas, 2009). Numerous sills and plutons, granitic to gabbroic, have intruded the stratigraphic units, mainly the Snowshoe Group. The Nicola and Snowshoe stratigraphic units are separated by the Eureka thrust fault (Thomas, 2009). Granitic sills are the most extensive of all igneous bodies. The Quesnel Lake gneiss protolith consists of megacrystic granite to granodiorite (Ferri et al., 1999; Ferri and Schiarizza, 2006). 
The region has undergone various degrees of deformation, magmatism, sedimentation, and

metamorphism. The highest intensity of deformation took place during the Early to Middle Jurassic (Ferri and Schiarizza, 2006). The obduction of the Quesnel arc rocks onto the Kootenay terrane appears to have been the cause of the intense deformation. This largely occurred along the Eureka thrust in the Northern Kootenay terrane (Ferri and Schiarizza, 2006). The ensuing obduction of the Quesnel arc rocks, southwest folding was accompanied by greenschist to amphibolite facies metamorphism. There have been multiple generations of folding and metamorphism throughout the region (Ferri and Schiarizza, 2006). The neighbouring Barkerville-Cariboo terrane boundary structures indicate similar fold patterns that postdate other events and are associated with a younger metamorphic event (Ferri and Schiarizza, 2006).

All sampled outcrops of this study are devoid of weathering and volcanic cone structures are well preserved in the study area, suggesting a young age for the sampled alkaline basalts. Recently, Kuehn et al. (2015) dated the volcanic rocks in the region (e.g., the Satah Mountain and Baldface Mountain volcanic fields) using ${ }^{40} \mathrm{Ar} /{ }^{39} \mathrm{Ar}$ geochronology. Only one sample was collected from the Tasse basalts and yielded an age of $0.174 \pm 0.007 \mathrm{Ma}$.

\section{Sampling}

Sampling was conducted on the Tasse property of Barker Minerals, near the north shore of Quesnel Lake (Figs. 1 and 2). A total of 61 samples were collected from six alkaline basalt volcanic centres (Fig. 3); 32 mantle xenoliths and 29 alkaline basalts (Fig. 4) (Supplementary Table 1, Supplementary Table 2). The sizes and weights ranged from $\sim 7 \mathrm{~cm}-20+\mathrm{cm}$ and $1 \mathrm{~kg}-$ $7+\mathrm{kg}$. The Global Positioning System (GPS) coordinates for sample locations are given in Supplementary Table 1 and Supplementary Table 2. 


\section{Methodology}

\subsection{Major and trace element analyses}

A total of 45 samples were selected for both major and trace element analyses (Tables 1 and 2). Major elements and specific trace elements ( $\mathrm{Ba}, \mathrm{Sr}, \mathrm{Y}, \mathrm{Sc}, \mathrm{Zr}, \mathrm{V}$ ) analyses were conducted by Thermo Jarrell-Ash ENVIRO II ICP, at Activation Laboratories Ltd. (Actlabs) in Ancaster, Ontario. The samples were fluxed using lithium metaborate and lithium tetraborate agents followed by digestion with nitric acid, 5\% solution (http://www.actlabs.com/).

Trace element analyses includes large ion lithophile elements (LILE; e.g., K, Rb, Ba), rare earth elements (REE; e.g., La-Lu), high field strength elements (HFSE; e.g., Zr, Hf, Nb, Ta). Analyses were conducted at Geoscience Laboratories (Geo Labs) in Sudbury, Ontario, using inductively coupled plasma-mass spectrometry (ICP-MS). The samples were digested by using multi-acid techniques (method code IM100) as detailed by Burnham et al. (2002).

Selected elements were normalized to chondrite (cn) (see McDonough and Sun, 1995) and average normal-mid-ocean ridge basalt (MORB) (see Sun and McDonough, 1989). The chondrite-normalized anomalies of $\mathrm{Ce} / \mathrm{Ce}^{*}\left[\mathrm{Ce}_{\mathrm{cn}} /\left(\mathrm{La}_{\mathrm{cn}} \mathrm{x} \mathrm{Pr}_{\mathrm{cn}}\right)^{0.5}\right]$ and $\mathrm{Eu} / \mathrm{Eu}^{*}$ were calculated with respect to the neighbouring elements (see Tables 1 and 2), following the method of Taylor and McLennan (1985). Similarly, N-MORB-normalized $\mathrm{Nb} / \mathrm{Nb}^{*}, \mathrm{~Pb} / \mathrm{Pb} *, \mathrm{Zr} / \mathrm{Zr}$, and $\mathrm{Ti} / \mathrm{Ti}^{*}$ anomalies were calculated with respect to the neighbouring elements (see Tables 1 and 2) using the same method. Mg-numbers were calculated as the molar ratio of $\mathrm{Mg} /\left(\mathrm{Mg}+\mathrm{Fe}^{2+}\right)$, where $\mathrm{Fe}^{2+}$ is assumed to be $90 \%$ of total Fe. 
Seven samples of alkaline basalts were selected for $\mathrm{Sr}, \mathrm{Nd}$ and $\mathrm{Pb}$ isotope analyses at the

231 Geological Institute, University of Copenhagen, Denmark. Details of analytical procedure are 232 given in Frei and Polat (2013). The powdered samples were dissolved through standard 233 procedures using concentrated $\mathrm{HNO}_{3}, \mathrm{HF}$ and $\mathrm{HCl}$ within Savillex ${ }^{\mathrm{TM}}$ beakers on a hotplate at $234130^{\circ} \mathrm{C}$ for 3 days. $\mathrm{A}^{150} \mathrm{Nd} /{ }^{147} \mathrm{Sm}$ spike was added before dissolution. The isotopic ratios of $\mathrm{Sm}$, $235 \mathrm{Nd}, \mathrm{Pb}$ and $\mathrm{Sr}$, and of $\mathrm{Sm}$ and $\mathrm{Nd}$ isotopic dilution concentrations were determined from 236 separately dissolved powder aliquots using a VG Sector 54 IT Thermal Ionization Mass 237 Spectrometer (TIMS).

238 Element separation was carried out using chromatographic columns charged with $12 \mathrm{ml}$ 239 AG50W-X 8 (100-200 mesh) cation resin, where Sr and REE fractions were collected. Rare 240 earth element fractions were further separated over smaller chromatographic columns containing 241 Eichrom's ${ }^{\mathrm{TM}}$ LN resin SPS (Part\#LN-B25-S). Strontium cuts were purified using a standardized $2423 \mathrm{M} \mathrm{HNO}_{3}-\mathrm{H}_{2} \mathrm{O}$ elution recipe on self-made disposable mini-extraction columns, following the 243 procedure of Horwitz et al. (1992). ${ }^{87} \mathrm{Rb} /{ }^{86} \mathrm{Sr}$ ratios were calculated using ICP-MS Rb and $\mathrm{Sr}$ 244 concentrations.

245 Samarium isotopes were measured in a static multi-collection mode, whereas $\mathrm{Nd}$ isotope 246 ratios were measured in a multi-dynamic routine, both on a triple Ta-Re-Ta filament setting. The 247 measured $\mathrm{Nd}$ isotope ratios were normalized to ${ }^{146} \mathrm{Nd} /{ }^{144} \mathrm{Nd}=0.7219$. The mean value of $248{ }^{143} \mathrm{Nd} /{ }^{144} \mathrm{Nd}$ ratios for the JNdi standard runs during the period in which the samples were 249 analyzed amounted to $0.512105 \pm 5(2 \sigma ; n=8)$. Precision for ${ }^{147} \mathrm{Sm} /{ }^{144} \mathrm{Nd}$ ratios is better than $2 \%$ $250(2 \sigma)$. 
252 glass stem and subsequently miniature glass stem anion exchange columns containing,

253 respectively, $1 \mathrm{ml}$ and $200 \mu \mathrm{l}$ of 100-200 mesh Bio-Rad AG $1 \times 8$ resin. Lead isotope ratios were

254 determined in a static multi-collection-mode where fractionation was controlled by repeated

255 analysis of the NBS 981 standard using values of Todt et al. (1993). Total procedural blanks

256 were below $<200 \mathrm{pg} \mathrm{Pb}$ which compared to $>100 \mathrm{ng} \mathrm{Pb}$ loads.

\section{6. Petrography}

\subsection{Mantle xenoliths}

The samples were studied using transmitting light microscopy and scanning electron microscope (SEM) with energy dispersive spectroscopy (EDS) to determine their textural and 262 compositional characteristics. The xenoliths are dominantly spinel lherzolites with minor dunite 263 and pyroxenite. They typically display a phaneritic, granoblastic texture, with triple junction 264 grain boundaries (Fig. 5). Several associations have been identified, such as pyroxene-spinel and 265 melt-fluid inclusions with pyroxene and spinel. A small number of samples exhibit small bands 266 of neoblasts with a mosaic-like texture. Olivine comprises the largest modal abundances $267(40-70 \%)$ in the xenoliths. They are typically subhedral, homogeneous, one to two millimeters in 268 size, colourless to pale yellow-green (Figs. 5 and 6), and are of forsterite (Fo87-93) composition.

Pyroxene grains are anhedral to subhedral, often fractured, constitute $30-50 \%$ of the 270 samples and are dominated by ca. one millimeter orthopyroxene (enstatite) and clinopyroxene

271 (diopside). Orthopyroxene grains are light brown and in some samples show evidence of 272 mineral-melt chemical reactions (resorption). Clinopyroxene grains are tinted green and contain, 
273 on average, 0.8 wt.\% Cr. Clinopyroxene also shows evidence of mineral-melt chemical reactions

274 displaying a mottled texture associated with fluid and/or melt inclusions (Figs. 5 and 6).

Spinel is the only major aluminous phase present and the least abundant mineral,

276 comprising approximately 5\% of the samples. Spinel grains are homogenous, reddish brown to

277 dark brown, 250-300 micrometers in size, and compositionally Cr-rich. The majority of spinel

278 grains are anhedral and sporadically display xenomorphic and skeletal textures (see also Mercier

279 and Nicolas, 1975). Spatially spinel is associated with clinopyroxene and occasionally displays

280 diffuse grain boundaries (Fig. 5).

281 Other studies of mantle xenoliths from within British Columbia reported similar

282 mineralogical and textural characteristics, with only minor differences (Littlejohn and

283 Greenwood, 1974; Brearley and Scarfe, 1984; Brearley et al., 1984; Sun and Kerrich, 1995;

284 Peslier et al., 2002; Greenfield et al., 2013). Some studies documented exsolution lamellae of

285 clinopyroxene within the orthopyroxene (Littlejohn and Greenwood, 1974; Peslier et al., 2002).

286 Augite-bearing mantle xenoliths were identified in numerous locations (Littlejohn and

287 Greenwood, 1974; Brearley and Scarfe, 1984; Peslier et al., 2002), as well as harzburgites

288 (Littlejohn and Greenwood, 1974; Peslier et al., 2002; Greenfield et al., 2013). A sample

289 containing pargasitic amphibole (mode $<5 \%$ ) was found in a Cr-diopside spinel lherzolite by 290 Brearley and Scarfe (1984) from Lightning Peak in British Columbia.

\subsection{Alkaline basalts}

The host rocks compositionally range from basanites to alkaline basalts and are very fine-

294 grained and vesicular (Fig. 7). Due to the fine-grained nature it is difficult to determine its exact 295 mineralogical composition. Plagioclase ( \pm nepheline) and pyroxene and Fe-Ti oxide phases were 
296 identified. Olivine fragments from the mantle xenoliths also exist. Olivine and plagioclase

297 display various skeletal textures (Fig. 7d). Several samples contain quartz xenocrysts with a 298 reaction rim of unknown fine-grained minerals.

299

300

301

302

303

304

305

306

307

308

309

310 311 Table 1).

312

313

314

315

316

317

318

\section{Results}

\subsection{Mantle xenoliths}

The mantle xenoliths are characterized by $42.8-45.2$ wt. $\% \mathrm{SiO}_{2}, 37.5-42.7$ wt.\% $\mathrm{MgO}$, 8.2-9.7 wt.\% $\mathrm{Fe}_{2} \mathrm{O}_{3}$ (Table 1). $\mathrm{Al}_{2} \mathrm{O}_{3}\left(0.85-4.61\right.$ wt.\%) and $\mathrm{TiO}_{2}(0.02-0.16$ wt.\%) show moderate variations, resulting in super-chondritic $\mathrm{Al}_{2} \mathrm{O}_{3} / \mathrm{TiO}_{2}(21-72)$ ratios (Table 1). $\mathrm{CaO}$ concentrations range from $0.61-3.8$ wt. $\%$, whereas the $\mathrm{CaO} / \mathrm{Al}_{2} \mathrm{O}_{3}$ possess a narrow range (0.71-0.92). They have rather restricted Mg-numbers $(89-92 \%)$ but are strongly depleted in incompatible elements $\left(\mathrm{Ba}=2-11 \mathrm{ppm} ; \mathrm{Sr}=3-31 \mathrm{ppm} ; \mathrm{Zr}=6-21 \mathrm{ppm}, \mathrm{K}_{2} \mathrm{O}=0.01-0.07\right.$ wt. $\left.\%\right)$ and variably depleted in transitional metals $(\mathrm{V}=41-95 \mathrm{ppm} ; \mathrm{Sc}=6-17 \mathrm{ppm})$ (Table 1). Yttrium (1-3 ppm) is also strongly depleted. Both $\mathrm{Zr} / \mathrm{Hf}$ and $\mathrm{Nb} / \mathrm{Ta}$ ratios show sub- to super-chondritic values $(\mathrm{Zr} / \mathrm{Hf}=34-60$ and $\mathrm{Nb} / \mathrm{Ta}=13-32)$ whereas $\mathrm{Y} / \mathrm{Ho}(25-31)$ retains a near-chondritic value (Fig. 8;

On the basis of chondrite-normalized REE patterns, samples are divided into three groups: (1) Group 1 has concave-up LREE patterns ( $\left.\mathrm{La} / \mathrm{Sm}_{\mathrm{cn}}=0.48-1.16 ; \mathrm{Gd} / \mathrm{Yb}_{\mathrm{cn}}=0.71-0.92\right)$ (Fig. 9a);

(2) Group 2 is characterized by flat to moderately LREE-enriched patterns $\left(\mathrm{La} / \mathrm{Sm}_{\mathrm{cn}}=1.14-1.92\right.$; $\mathrm{Gd} / \mathrm{Yb}_{\mathrm{cn}}=0.87-1.09$ ) (Fig. 9b); and (3) Group 3 displays strongly LREE-enriched patterns $\left(\mathrm{La} / \mathrm{Sm}_{\mathrm{cn}}=1.53-2.45 ; \mathrm{Gd} / \mathrm{Yb}_{\mathrm{cn}}=1.00-1.32\right)$ (Fig. 9c). All three groups display negative Ti anomalies $\left(\mathrm{Ti} / \mathrm{Ti}^{*}{ }_{\mathrm{MORB}}=0.68-0.95\right)$ relative to $\mathrm{Eu}$ and $\mathrm{Gd}$ (Table 1; Fig. 9e-g and 10). In all Groups, $\mathrm{Zr}$ displays positive anomalies $\left(\mathrm{Zr} / \mathrm{Zr}^{*}{ }_{\mathrm{MORB}}=1.11-2.13\right)$ relative to $\mathrm{Sm}$ and $\mathrm{Eu}$ (Table 1; 
Figs. 9e-g and 10). Two outlier samples (TA-2012-14, TA-2012-25) do not fit into the initial three groupings and display separate geochemical signatures (Fig. 9d and h). These two outlier samples represent the highest Mg-numbers of 90.6 and 91.9 , as well, $\mathrm{La} / \mathrm{Sm}_{\mathrm{cn}}$ ratios 5.65 and 6.65, respectively (Table 1). TA-2012-14 possesses the highest $\mathrm{Al}_{2} \mathrm{O}_{3} / \mathrm{TiO}_{2}$ ratio of 72 (Table 1). The outlier samples also have larger positive $\mathrm{Zr}$ anomalies $\left(\mathrm{Zr} / \mathrm{Zr}^{*}{ }_{\text {моRB }}=3.37-4.78\right)$ than the rest of samples (Fig. 9h). All samples have negative $\mathrm{Nb}$ anomalies $\left(\mathrm{Nb} / \mathrm{Nb}^{*}{ }_{\text {MORB }}=0.18-0.89\right)$ relative to $\mathrm{U}$ and $\mathrm{K}$ (Fig. 9).

\subsection{Alkaline basalts}

The Tasse alkaline basalts are characterized by low $\mathrm{SiO}_{2}(44.2-46.0$ wt.\%) values. They have moderately variable $\mathrm{MgO}$ (6.5-10.2 wt.\%), $\mathrm{CaO}$ (7.5-8.6 wt.\%), $\mathrm{Fe}_{2} \mathrm{O}_{3}$ (12.9-14.9 wt.\%), and $\mathrm{Al}_{2} \mathrm{O}_{3}(13.6-15.0$ wt.\%) contents (Table 2). Mg-numbers (\%) vary between 47 and 59. High total alkaline element values $\left(\mathrm{Na}_{2} \mathrm{O}+\mathrm{K}_{2} \mathrm{O}=5.1-6.6\right.$ wt.\%) (Table 2) are consistent with an alkaline basalt composition. They have highly fractionated REE patterns $\left(\mathrm{La} / \mathrm{Sm}_{\mathrm{cn}}=3.15-3.80\right.$; $\mathrm{Gd} / \mathrm{Yb}_{\mathrm{cn}}=3.42-4.61$ ) (Fig. 11a), consistent with an alkaline basalt affinity. They are strongly enriched in incompatible elements (e.g., $\mathrm{TiO}_{2}=2.38-3.1$ wt.\%; $\mathrm{Ba}=580-797$ ppm; $\mathrm{Sr}=872-993$ ppm; $\mathrm{Zr}=302-383 \mathrm{ppm}$ ) (Fig. 11b). High $\mathrm{Zr}$ and low $\mathrm{Y}$ (24-27 ppm) concentrations resulting in high $\mathrm{Zr} / \mathrm{Y}=12-14$. The basalts display positive anomalies of $\mathrm{Zr}\left(\mathrm{Zr} / \mathrm{Zr}{ }^{*}{ }_{\text {моRB }}=1.32-1.51\right)$ and negative $\mathrm{Ti}\left(\mathrm{Ti} / \mathrm{Ti}^{*}{ }_{\mathrm{MORB}}=0.80-0.96\right)$ anomalies (Table 2$)$. Niobium shows slight positive anomalies $\left(\mathrm{Nb} / \mathrm{Nb}^{*}{ }_{\text {MORB }}=0.98-1.18\right)$ (Table 2). The samples are uniform in composition and exhibit very narrow ranges amongst major and trace elements. 
343

344

345

346

347

348

349

350

351

352

353

354

355

356

357

358

359

360

361

362

363

364

\subsection{Strontium, neodymium and lead isotopes of the alkaline basalts}

The Tasse basalts have very small ranges of ${ }^{87} \mathrm{Sr} /{ }^{86} \mathrm{Sr}(0.703346-0.703591) .{ }^{87} \mathrm{Rb} /{ }^{86} \mathrm{Sr}$ ratios range from 0.1185 to 0.1269 (Table 3). They have uniform ${ }^{143} \mathrm{Nd} /{ }^{144} \mathrm{Nd}$ $(0.512834-0.512922)$ and ${ }^{147} \mathrm{Sm} /{ }^{144} \mathrm{Nd}(0.1093-0.1117)$ ratios, yielding large positive $\varepsilon \mathrm{Nd}(+3.8$ to +5.5 ) values (Table 4). Depleted mantle model ages range between 338 and $474 \mathrm{Ma}$. Like $\mathrm{Sr}$ and $\mathrm{Nd}$ isotopes, $\mathrm{Pb}$ isotopes also display very narrow variations $\left({ }^{206} \mathrm{~Pb} /{ }^{204} \mathrm{~Pb}=19.40-19.58\right.$; $\left.{ }^{207} \mathrm{~Pb} /{ }^{204} \mathrm{~Pb}=15.57-15.60 ;{ }^{208} \mathrm{~Pb} /{ }^{204} \mathrm{~Pb}=38.99-39.14\right)$ (Table 5). Figure 12 compares the $\mathrm{Sr}, \mathrm{Nd}$ and $\mathrm{Pb}$ isotopic compositions of the Tasse alkaline basalts with MORB, OIB, HIMU, and FOZO, and with basalts from various arcs, forearcs, backarcs and continental flood basalt provinces. On ${ }^{87} \mathrm{Sr} /{ }^{86} \mathrm{Sr}$ versus ${ }^{143} \mathrm{Nd} /{ }^{144} \mathrm{Nd},{ }^{206} \mathrm{~Pb} /{ }^{204} \mathrm{~Pb}$ versus ${ }^{207} \mathrm{~Pb} /{ }^{204} \mathrm{~Pb},{ }^{206} \mathrm{~Pb} /{ }^{204} \mathrm{~Pb}$ versus ${ }^{208} \mathrm{~Pb} /{ }^{204} \mathrm{~Pb}$, and

${ }^{206} \mathrm{~Pb} /{ }^{204} \mathrm{~Pb}$ versus ${ }^{87} \mathrm{Sr} /{ }^{86} \mathrm{Sr}$ diagrams, the alkaline basalts plot in the OIB field. They also plot close to the FOZO field.

\section{Discussion}

\subsection{Source characteristics of the mantle xenoliths}

The concave-upward LREE patterns of Group 1 xenoliths are similar to those of Phanerozoic boninites and forearc peridotites, reflecting the addition of $\mathrm{La}, \mathrm{Ce}$ and $\operatorname{Pr}$ to a strongly LREE-depleted mantle domain (see Pearce et al., 1992; König et al., 2010). Similarly, Group 1 xenoliths share the super-chondritic $\mathrm{Al}_{2} \mathrm{O}_{3} / \mathrm{TiO}_{2}(32-34)$ ratios, MORB-normalized negative $\mathrm{Nb}(0.14-0.34)$ and $\mathrm{Ti}(0.84-0.93)$, and positive $\mathrm{Rb}, \mathrm{U}, \mathrm{K}, \mathrm{Pb}(4.51-5.12)$ and $\mathrm{Zr}$ (1.37-2.13) anomalies of Phanerozoic boninites (see Pearce et al., 1992; König et al, 2010). These geochemical characteristics are collectively consistent with the enrichment of a highly 
365 depleted mantle domain by subduction-derived melts and/or fluids in a sub-arc mantle wedge.

366 Although Group 2 and Group 3 xenoliths share the enrichment of LILE (Rb, Ba, K), LREE, Th,

$367 \mathrm{U}, \mathrm{Pb}, \mathrm{Zr}$, Hf of Group 1 xenoliths, they have higher abundances of all these elements than

368 Group 1 xenoliths (Fig. 9), suggesting that the sources of Group 2 and Group 3 xenoliths

369 underwent more extensive metasomatic enrichment than the source of Group 1 xenoliths by

370 subduction-derived melts and/or fluids. Different degrees of enrichment in the sources of Groups

371 1, 2 and 3 xenoliths are consistent with the existence of heterogeneous mantle domain beneath

372 the Omineca belts (Supplementary Fig. 1) and differential metasomatic enrichment processes in

373 the sub-arc mantle wedge beneath southeastern British Columbia.

374 The distinct geochemical characteristics of samples TA-2012-14 and TA-2012-25 are also

375 consistent with heterogeneous mantle domains beneath the Omineca belts. Sample TA-2012-14

376 is a spinel lherzolite and shows evidence of extensive melt metasomatism modifying

377 clinopyroxene (Fig. 5 e-f), resulting in a resorption texture and an LREE-enriched, U-shaped

378 pattern with mild MREE depletion (Fig. 9d). Sample TA-2012-25 is a dunite and dominated by

379 high LREE and lower HREE typical of LREE-enriched dunitic samples (Fig. 9d). These samples

380 display strong $\mathrm{U}, \mathrm{K}, \mathrm{Pb}, \mathrm{P}, \mathrm{Zr}$ and $\mathrm{Hf}$ anomalies, as well as Th. Negative anomalies are 381 associated with $\mathrm{Nb}(\mathrm{Ta})$ and Ti (Fig. 9h).

382 Mantle xenoliths have been identified globally and in different tectonic environments 383 (Ionov et al., 2006; Arai et al., 2007; Zheng et al., 2007; Lu et al., 2013). It is well known that the 384 Canadian Cordillera has been formed through many periods of accretion due to subduction and 385 arc related tectonism (Gabrielse et al., 1991; Price, 1994; Hart, 1999; Monger and Price, 2002; 386 Eyles and Miall, 2007; Monger, 2014). Ultramafic rocks occurring in different geodynamic 387 settings have distinct rock associations and geochemical signatures (Bodinier and Godard, 2003; 
Beccaluva et al., 2004; Ishizuka et al, 2014; Khedr et al., 2014). In order to constraint their origin, the geochemistry of the mantle xenoliths in the Canadian Cordillera are compared with those of ultramafic rocks formed in forearcs, ophiolites and orogenic massifs.

\subsubsection{Comparison with other Phanerozoic ultramafic rocks}

Forearc ultramafic rocks are commonly represented by serpentinized harzburgites and dunites with subordinate pyroxenites and lherzolites (Ishii et al, 1992; Pearce et al., 1992; Parkinson and Pearce, 1998; Pearce et al., 2000; Hyndman and Peacock, 2003; Beccaluva et al., 2004; Ishizuka et al, 2014). Harzburgites and dunites are characteristics of a highly depleted mantle source and have high Mg-numbers (92-94) (Ishiwatari, 1985; Ishii et al., 1992; Artemieva, 2011). Chondrite-normalized patterns indicate strongly depleted sources (Parkinson and Pearce, 1998), with heavy LREE-depletion and positive incline towards the HREE component, leading to lower MREE/HREE and LREE/HREE values. Strong depletion of LREE, relative to HREE, and high Mg-numbers have been attributed to high degrees of partial melting and multiple stages of melt extraction (Ishiwatari, 1985; Ishii et al., 1992; Pearce et al., 2000; Artemieva, 2011).

Ophiolites are representative sections of oceanic lithosphere (crust and upper mantle) that have been accreted to the continental lithosphere (Bodinier and Godard, 2003; Metcalf and Shervais, 2008; Pearce, 2008; Dilek and Furnes, 2014; Furnes et al., 2014, 2015; Pearce, 2014). Many major orogenic belts, such as the Himalayan, Appalachian, Altaids, and Alpine orogenic belts, contain numerous ophiolite complexes (Bodinier and Godard, 2003; Şengör and Natal'in, 2004; Eyuboglu et al., 2007; Hanghøj et al., 2010; Dilek and Furnes, 2011, 2014; Uysal et al., 2012; Santosh et al., 2013; Khedr et al., 2014, Pearce, 2014). The ultramafic basal section of 
411 ophiolites may contain lherzolitic (Internal Ligurides, Western Alps) and/or harzburgitic (Semail 412 ophiolite, Oman) rock types (Bodinier and Godard, 2003; Hanghøj et al., 2010; Dilek and 413 Furnes, 2014). Most ophiolites do not have the complete rock association as defined in the 414 Penrose Conference in 1972 (Anonymous, 1972), as their mantle section tend to be fragmented 415 and destroyed during their accretion (Kusky, 2004; Dilek and Furnes, 2011, 2014; Furnes et al., 416 2014, 2015). Ophiolitic lherzolites are more commonly distinguished by 'N-MORB' type 417 patterns, demonstrated by LREE-depletion in chondrite-normalized plots (Bodinier and Godard, 418 2003; Hanghøj et al., 2010; Khedr et al., 2014). Similar to harzburgites, ophiolitic lherzolites 419 occasionally exhibit minor to moderate positive slope towards the HREE, which differs from the 420 'N-MORB' type flat MREE to HREE patterns (Bodinier and Godard, 2003; Khedr et al., 2014).

421 Orogenic peridotite massifs are characterized by a predominance of lherzolites with minor 422 harzburgites and dunites (Bodinier and Godard, 2003). Contrasting with ophiolitic peridotites, 423 orogenic massifs do not show specific structural sequences (Bodinier and Godard, 2003). 424 Orogenic massifs are representative of fertile mantle ( $>10 \%$ clinopyroxene) and commonly 425 dominated by spinel peridotites of intermediate pressure (Bodinier and Godard, 2003). 426 Petrologically and geothermbarometrically orogenic massifs are divided into three types: (1) 427 high-(ultra-high)-pressure (garnet-bearing) peridotites, (2) intermediate pressure (spinel-bearing) 428 peridotites, and (3) low pressure (plagioclase-bearing) peridotites (Bodinier and Godard, 2003). 429 Serpentinized massifs are of low pressure within the plagioclase stability field and have been 430 known to show evidence of recrystallization within the lower pressure environment (Bodinier 431 and Godard, 2003).

432 The major element composition of the Tasse lherzolites is comparable to other spinel 433 lherzolites from various localities in British Columbia (Peslier et al., 2002; Francis et al., 2010; 
434 Greenfield et al., 2013). Similarly, the lherzolites studied by Peslier et al. (2002) are akin to the 435 Tasse xenoliths, by showing distinctive groupings of LREE-depleted and moderately to more 436 strongly LREE-enriched (Fig 9). Lherzolites reported by Peslier et al. (2002) show negative Zr, $437 \mathrm{Hf}, \mathrm{Ti}, \mathrm{Nb}$, Ta anomalies and are variable in LILE. The negative $\mathrm{Zr}$ and $\mathrm{Hf}$ anomalies are not 438 common with the Tasse suite, which may be due to heterogeneity in source composition or 439 metasomatism. The LREE enrichment factors also differ. The most depleted lherzolites studied 440 by Peslier et al. (2002) show no LREE enrichment compared the Tasse Group 1 lherzolites. The 441 sources of LREE enrichment may be attributed to metasomatism by either melt or subduction 442 fluids and are variable in extent. The Tasse xenoliths are representative of pieces of a variably 443 metasomatized sub-arc mantle emplaced by alkaline basalt upwelling.

444 The major difference between the Tasse mantle xenoliths and ultramafic rocks from a 445 forearc setting, ophiolites and massif peridotite is that the latter rocks are strongly serpentinized. 446 In contrast to the dry nature of the Tasse mantle xenoliths (LOI $<1$ wt.\%), ultramafic rocks from 447 forearc settings, ophiolites and massif peridotites are strongly hydrated (LOI $>8$ wt.\%).

448 Forearc harzburgites and dunites (Parkinson and Pearce, 1998) contain notable 449 geochemical differences compared with the Tasse xenoliths. Izu-Bonin-Mariana forearc samples 450 contain higher $\mathrm{MgO}$ and lower $\mathrm{Fe}_{2} \mathrm{O}_{3}, \mathrm{CaO}, \mathrm{Al}_{2} \mathrm{O}_{3}$ and $\mathrm{Na}_{2} \mathrm{O}$ values. Distinctively lower $\mathrm{Zr}(<0.3$ $451 \mathrm{ppm})$ and greater $\mathrm{Ni}(2400-3100 \mathrm{ppm})$ values are also notable compared with the Tasse 452 lherzolites (Table 1). Along with $\mathrm{Zr}$, other HFSE, and $\mathrm{Th}$ and $\mathrm{U}$ are more enriched in the Tasse 453 xenoliths. Both the Tasse and Izu-Bonin-Mariana xenoliths show comparable fluctuations in 454 LILE (e.g., K, Rb, Sr, Ba), as seen in many arc environments (Pearce et al., 2000; Arai et al., 455 2007; Ishizuka et al., 2014). Chondritic Y/Ho ( 28) and sub- to superchondritic $\mathrm{Nb} / \mathrm{Th}$ values 456 (2-13) are representative of the Tasse xenoliths. Izu-Bonin-Mariana forearc samples display 
457 larger variation in $\mathrm{Y} / \mathrm{Ho}(15-35)$ and subchondritic $\mathrm{Nb} / \mathrm{Th}$ (1-5). The Tasse xenoliths represent a

458 less depleted source with less alteration and notably there is an absence of harzburgites and 459 serpentinization (serpentine minerals; e.g., antigorite, chrysotile).

460 The most depleted Tasse xenoliths (Group 1), show higher LREE ( $\left.\mathrm{La} / \mathrm{Sm}_{\mathrm{cn}}=0.48-1.16\right)$ 461 and enriched HREE $\left(\mathrm{Gd} / \mathrm{Yb}_{\mathrm{cn}}=0.71-0.92\right)$ patterns compared with ophiolitic lherzolites $462\left(\mathrm{La} / \mathrm{Sm}_{\mathrm{cn}}=0.29-0.78\right.$ and $\left.\mathrm{Gd} / \mathrm{Yb}_{\mathrm{cn}}=0.27-0.65\right)($ Khedr et al., 2014). Ophiolites, similar to forearc 463 settings, represent a more depleted source than is seen in the Tasse suites, although geochemical 464 similarities are notable. Both ophiolitic and Tasse lherzolites contain similar MgO (43-46 wt.\%) 465 and $\mathrm{CaO}\left(2.0-3.7\right.$ wt.\%) content. The Tasse lherzolites contain higher $\mathrm{TiO}_{2}, \mathrm{Al}_{2} \mathrm{O}_{3}, \mathrm{Fe}_{2} \mathrm{O}_{3}$ and $466 \mathrm{Na}_{2} \mathrm{O}$ compared with ophiolites. Ophiolitic xenoliths contain similar $\mathrm{Cr}$ and slightly lower $\mathrm{V}$ and 467 Ni contents. The greater variability of $\mathrm{Eu} / \mathrm{Eu}_{\mathrm{cn}}$ in ophiolitic lherzolites is not seen in the Tasse 468 xenoliths $\left(\mathrm{Eu} / \mathrm{Eu}_{\mathrm{cn}}=\right.$ avg. 1.01).

469 Studies from China have shown an abundance of mantle xenoliths present, brought to the 470 surface by both basaltic rocks and kimberlites (Menzies et al., 1993; Wang et al., 1998; Wu et 471 al., 2003, 2006; Xu et al., 2003; Chu et al., 2009). The majority of mantle xenoliths found 472 throughout China are spinel lherzolites, harzburgites, dunites, wehrlites and pyroxenites (Wu et 473 al., 2003, 2006; Xu et al., 2003; Chu et al., 2009). Garnet-bearing xenoliths are also present and 474 are more commonly sampled by kimberlites from deeper mantle sources (Menzies et al., 1993; 475 Wang et al., 1998; Chu et al., 2009). Lherzolites found within China share the major and trace 476 element characteristics of the Tasse xenolith suite (see Chu et al., 2009). The more refractory 477 dunites and harzburgites from the Mengyin kimberlites show evidence of LREE-enrichment 478 (Chu et al., 2009), as the dunite sample from the Tasse suite. Spinel lherzolites hosted by the 479 Penglai basalts exhibit similar enrichment patterns to the Group 2 and Group 3 spinel lherzolites 
480 of the Tasse suite (Chu et al., 2009). The trace element patterns indicate variable metasomatic

481 enrichment throughout the lithospheric mantle beneath China (Menzies et al., 1993; Wang et al.,

482 1998; Wu et al., 2003, 2006; Xu et al., 2003; Chu et al., 2009). Mineralogically, mantle xenolith

483 samples from China show evidence of both melt and hydrous metasomatism (Wu et al., 2003,

484 2006; Xu et al., 2003; Chu et al., 2009). Evidence of hydrous metasomatism is supported by the

485 presence of phlogopite-, amphibole- and apatite-bearing mantle peridotites (Xu et al., 2003; Wu

486 et al., 2006), which differs from the Tasse suite wherein no hydrous minerals have been

487 recognized.

488 The Tasse xenoliths more closely resemble orogenic spinel lherzolites of the Lanzo and

489 Lherz massifs (Le Roux et al., 2007; Riches and Rogers, 2011; Guarnieri et al., 2012). Field

490 relationships of the Tasse xenoliths did not exhibit any particular structure or patterns. The

491 xenoliths appeared as nodules or massif bodies emplaced within the alkaline basalts.

492 Geochemically ophiolites and orogenic massifs share similarities; however, the LREE patterns of

493 the Tasse lherzolites are more representative of the orogenic Lherz lherzolites showing elevated

494 signatures and a moderate incline towards the HREE (Riches and Rogers, 2011; Khedr et al., 495 2014). Major element signatures and Mg-numbers compared with the orogenic North Lanzo 496 spinel lherzolites (Guarnieri et al., 2012) are virtually identical. Cardinal differences include $497 \mathrm{Fe}_{2} \mathrm{O}_{3}, \mathrm{HFSE}$, Th and $\mathrm{U}$ which are higher in the Tasse xenoliths. The elevated abundance in the 498 aforementioned elements can be attributed to arc processes. There are no distinctive differences 499 amid $\mathrm{Y} / \mathrm{Ho}$ values $(28)$ or $\mathrm{Eu} / \mathrm{Eu}^{*}{ }_{\text {cn }}(\sim 1.0)$. There is a minor difference in Ni concentration, likely 500 due to modal olivine abundances. The Tasse xenoliths more closely resemble orogenic spinel 501 lherzolites of the Lanzo and Lherz massifs (Le Roux et al., 2007; Riches and Rogers, 2011; 502 Guarnieri et al., 2012). 


\subsection{The petrogenetic origin of the Tasse alkaline lavas}

The Tasse basalts are uniform in composition. They have $\mathrm{La} / \mathrm{Sm}_{\mathrm{cn}}(3.15-3.80), \mathrm{Gd} / \mathrm{Yb}_{\mathrm{cn}}$ (3.42-4.61), $\mathrm{Zr} / \mathrm{Y}$ (13-14), $\mathrm{Nb} / \mathrm{Y}(2.6-3.0)$ and $\mathrm{Th} / \mathrm{Yb}(3.04-3.80)$ ratios (Table 2), and high alkaline element (e.g., $\mathrm{Na}_{2} \mathrm{O}, \mathrm{K}_{2} \mathrm{O}, \mathrm{Rb}$ ) contents, consistent with an incompatible-element enriched mantle source. The trace element systematics suggests a homogeneous mantle source or homogenized magma chamber(s). Negative Ti anomalies (0.80-0.96) may have resulted from a Ti-bearing mineral fractionation, possibly ilmenite or magnetite, as they are common accessory minerals in mafic rocks (see Barnes and Roeder, 2001). Eu/Eu* values are constant; and average 1.01 , indicating that plagioclase was not a major fractionating phase.

The alkaline lavas are Cenozoic and scattered throughout British Columbia (Brearley et al., 1984; Carr, 1995; Sun and Kerrich, 1995; Peslier et al., 2002; Abraham et al., 2005; Sluggett, 2008; Kuehn et al., 2015). The origin of the alkaline basalts is attributed to partial melting of an enriched mantle source by either metasomatism or crustal contamination (Wilshire et al, 1980; Wilshire et al., 1988). Considering the metasomatic nature of the mantle xenoliths, the partial melting of an enriched mantle source model is highly probable, although the aforementioned models remain heavily debated. Kuehn et al. (2015) attributed the origin of alkaline basalts in the Satah Mountain and Baldface Mountain volcanic fields to a hot spot beneath central British Columbia.

On ${ }^{87} \mathrm{Sr} /{ }^{86} \mathrm{Sr}$ versus ${ }^{143} \mathrm{Nd} /{ }^{144} \mathrm{Nd},{ }^{206} \mathrm{~Pb} /{ }^{204} \mathrm{~Pb}$ versus ${ }^{87} \mathrm{Sr} /{ }^{86} \mathrm{Sr},{ }^{206} \mathrm{~Pb} /{ }^{204} \mathrm{~Pb}$ versus ${ }^{207} \mathrm{~Pb} /{ }^{204} \mathrm{~Pb}$, and ${ }^{206} \mathrm{~Pb} /{ }^{204} \mathrm{~Pb}$ versus ${ }^{208} \mathrm{~Pb} /{ }^{204} \mathrm{~Pb}$ diagrams, the Tasse alkaline basalts plot in the OIB field, and are located between MORB and FOZO fields, consistent with an asthenospheric mantle source (Fig. 12). They plot away from the Turkish-Iranian Plateau, the Andean southern Volcanic Zone, the Izu-Bonin forearc, the Kuril arc, the Aleutian arc and the Scotia Ridge basalts on the 
$526 \mathrm{Sr}-\mathrm{Nd}-\mathrm{Pb}$ isotope diagrams (Fig. 12), suggesting that they are not derived from a subduction527 modified mantle source.

528 The following trace element and $\mathrm{Sr}-\mathrm{Nd}-\mathrm{Pb}$ isotope characteristics are inconsistent with 529 significant crustal contamination of the Tasse alkaline basalts: (1) $\mathrm{La} / \mathrm{Nb}(0.68-0.73)$; (2) low $530 \mathrm{Th} / \mathrm{Nb}_{\text {cn }}\left(0.61-0.72\right.$ ); (3) low $\mathrm{Al}_{2} \mathrm{O}_{3} / \mathrm{TiO}_{2}$ (4.6-5.7); (4) Eu/Eu* (avg. 1.02); (5) Nb/Nb* (avg. 531 1.06); (6) large positive $\varepsilon \mathrm{Nd}(+3.8$ to +5.5$)$ values; and (7) low ${ }^{87} \mathrm{Sr} /{ }^{86} \mathrm{Sr}$ values 532 (0.703346-0.703591) (Tables 2-5) (cf., Taylor and McLennan, 1995; Hofmann, 1997; Polat et 533 al., 1997; Rudnick and Gao, 2003; Kamgang et al., 2008; Yanagi, 2011; Li et al., 2014). Cenozoic alkaline magmatism was not only common in British Columbia but also 535 widespread globally (Wilshire et al., 1988; Polat et al., 1997; Colgan et al., 2006; Camp and 536 Hanan, 2008; Hidas et al., 2010; Nkouandou and Temdjim, 2011; Putirka and Platt, 2012; Camp 537 et al., 2013). Many of these alkaline basaltic lavas (e.g., Argentina, Cameroon, China, Hungary, 538 Oman) host mantle xenoliths (Chen et al., 2007, 2014; Dantas et al., 2009; Grégoire et al., 2009; 539 Hidas et al., 2010; Nkouandou and Temdjim, 2011; Liu et al., 2012; Li et al., 2014). Alkaline 540 lavas in many of these locations share some geochemical similarities to the Tasse alkaline basalts 541 but originated in differing tectonic settings.

542 The Tasse alkaline lavas in British Columbia share many geochemical characteristics of 543 the Cenozoic alkaline lavas erupted in different parts of the world (Polat et al. 1997; Chen et al., 544 2007; Dantas et al., 2009; Grégoire et al., 2009; Hidas et al., 2010; Nkouandou and Temdjim, 545 2011; Liu et al., 2012; Li et al., 2014; Zhao et al., 2014). The Tasse alkaline basalts 546 compositionally more akin to those of the Guantao group and NG-130 of the Cameroon Line, 547 although the degree of source enrichments, mineral fractionation processes and geodynamic 548 processes may differ (see Nkouandou and Temdjim, 2011). 
The Tasse alkaline basalts possess higher ${ }^{143} \mathrm{Nd} /{ }^{144} \mathrm{Nd}$ but lower ${ }^{87} \mathrm{Sr} /{ }^{86} \mathrm{Sr}$ ratios than the

550

551

552

553

554

555

556

557

558

559

560

561

562

563

564

565

566

567

568

569

570

571

Deccan Trap and the Turkish-Iranian Plateau basalts, signifying less interaction with the continental crust than the Deccan Trap and the Turkish-Iranian Plateau basalts (Fig. 12). In addition, the Tasse basalts have higher ${ }^{206} \mathrm{~Pb} /{ }^{204} \mathrm{~Pb}$ ratios than basalts in the North Queensland, the Turkish-Iranian Plateau and the Payenia Volcanic Province of the southern Andes (Fig. 12), suggesting higher ${ }^{238} \mathrm{U} /{ }^{204} \mathrm{~Pb}$ values in source of the Tasse basalts than in those of the North Queensland, the Turkish-Iranian Plateau and the Payenia Volcanic Province counterparts.

\subsection{Geodynamic constraints on the origins of Cenozoic alkaline lavas in British Columbia}

An early framework for the Late Cenozoic volcanism in the Canadian Cordillera was provided by Bevier et al. (1979) and Souther (1991) who divided the region into a series of belts and fields, each with a distinctive rationale such as subduction, extension or mantle plume activity. Since then, numerous studies of the volcanic belts have provided additional information on age and petrogenesis (e.g., Edwards and Russell, 2000; Preece and Hart, 2004; Abraham et al., 2005; Sluggett, 2008; Manthei et al., 2010; Mullen and Weis, 2013; Kuehn et al., 2015). Studies of subducted slab geometry (Breitsprecher et al., 2003; Madsen et al., 2006) and mantle tomography (Frederiksen et al., 1998; Audet et al., 2008; Mercier et al., 2009; and Bao et al., 2014) have provided additional constraints and insights into the crustal and mantle environments and the processes responsible for the magmatism.

The most fundamental geological elements in the region are the subducted slabs and the intervening Northern Cordilleran Slab Window which divide the region into two volcanic arcs and an intervening field of slab window-associated volcanoes (Thorkelson and Taylor, 1989; Madsen et al., 2006). The slab window-related field is approximately $2000 \mathrm{~km}$ long and is 
572 characterized by mafic, alkalic compositions with intra-oceanic trace element profiles. Localized

573 magmatism in this field began in the Oligocene, became widespread during the Miocene to

574 Pliocene, and contracted to fewer localities in the Pleistocene and Holocene (Edwards and

575 Russell, 2000). Clearly, the absence of slab beneath this region was a fundamental control on the 576 compositions of the volcanoes, few of which bear supra-subduction zone signatures.

577 Thorkelson et al. (2011) suggested that diffuse upwelling through the slab window resulted 578 in low-degree decompressional anatexis of both asthenospheric and lithospheric reservoirs and 579 was the primary mechanism of the magmatism. However, the field of intraplate volcanism is 580 both wide and long, and additional causes of magmatism have been proposed and deserve 581 exploration. Focused mantle upwelling in the form of a small plume may have been responsible 582 for the Anahim belt (Souther, 1986; Kuehn et al., 2015), although the younging of volcanism 583 from west to east (Kuehn et al., 2015) is not as consistent as might be expected, the topographic 584 elevation of the region is modest, and tomographically identified slowness anomalies (Audet et 585 al., 2008; Mercier et al. 2009) are not particularly deep or well defined.

Lithospheric extension related to intervals of divergence between the Pacific and North 587 American plates (Edwards and Russell, 2000) has also been proposed and appears to be 588 particularly relevant to the central part of the intraplate field where Neogene graben development 589 and faulting have been documented (Souther, 1991; Edwards and Russell, 2000). However, 590 many of the intraplate volcanoes are located where no extensional structures have been 591 identified, and the degree of extension within most of the Canadian Cordillera during Miocene 592 and later times appears to be low and unlikely to trigger mantle melting. Nevertheless, localized 593 extensional faulting may have provided conduits for magma that was produced by other means 594 such as upwelling and decompression. 
Back-arc style mantle convection and melting behind the Garibaldi arc in southern British

596 Columbia remains as a viable mechanism to form the Chilcotin Group (Bevier et al., 1979).

597 However, these back-arc lavas are broadly similar to those found elsewhere in the intraplate belt,

598 suggesting a common mechanism. Appealing solely to mantle stirring by the subducting Juan de

599 Fuca slab for these lavas may be problematic, however, because the Chilcotin Group extends

600 northward beyond the modeled extent of subducted slab of the Juan de Fuca plate and merges

601 with the so-called Anahim hot-spot track. The back-arc model for this area, however, is strongly

602 supported by the geophysical modeling of Currie and Hyndman et al. (2006) who invoked small-

603 domain mantle convection within the asthenosphere behind the arc. That model may be broadly

604 applicable to magmatism and high heat flow in southern British Columbia, but appears to be

605 unable to account for Miocene to Holocene volcanism in the central and northern parts of the

606 intraplate belt which have not lain behind a volcanic arc since the Paleogene (Madsen et al.,

607 2006). Moreover, some of the magmatism and high heat flow in southern British Columbia may

608 be related to tears and breaches in the downgoing slab (Madsen et al., 2006; Sluggett, 2008;

609 Mullen and Weis, 2013).

610 Another model for high heat flow and magmatism in the intraplate field is lithospheric

611 delamination and orogenic collapse in the Paleogene (Ranalli et al, 1989; Bao et al., 2014). In

612 this model, delamination removed much of the previously extant lithospheric mantle in the 613 central and western Cordillera, contributing to Paleocene to Eocene magmatism and leaving 614 behind a thin layer of lithospheric mantle. As noted by Francis et al. (2010), the mantle 615 lithosphere appears to have undergone thinning in the Neogene, a process that would require 616 additional thermal erosion, albeit of a mantle lithosphere that may have been catastrophically 617 thinned during the Paleogene. 

622 Columbia.

623

624

625

626

627

628

629

630

631

632

633

634

635

636

637

638

639

640

\subsection{Characteristics of the lithospheric mantle beneath southeastern British Columbia}

Understanding the origin of the Tasse alkaline basalts and their mantle xenoliths requires

the assessment of the degrees of partial melting, source characteristics and the nature of metasomatism associated with subduction and arc generating processes in southeastern British

The Tasse mantle xenoliths represent a section of mantle beneath southeastern British Columbia. The major element characteristics of the xenoliths indicate the mantle has emanated from melt extraction of a relatively fertile source (Fig. 13) (Canil and Lee, 2009). Modal clinopyroxene has been used to estimate mantle fertility (Parkinson and Pearce, 1998). The Tasse lherzolites contain $\sim 10-15 \%$ clinopyroxene. Depletion of LREEs in the Tasse lherzolites reflects extraction of basaltic melts from their sources (cf., Peslier et al., 2002; Pearce and Stern, 2006). There is no evidence to suggest a single partial melting event and based on subduction and arc forming history of British Columbia, the removal of basaltic partial melts may have occurred over a large time span. The elevated Mg-numbers are also indicative of a source that underwent various degrees of partial melting (cf., Ishiwatari, 1985; Ishii et al, 1992; Parkinson and Pearce, 2008). Although the Tasse xenolith suite contains only one representative dunite sample, harzburgites have been found in other localities within British Columbia. These more refractory mantle xenoliths typically contain higher Mg-numbers stemming from high degrees of partial melting (see Ishiwatari, 1985; Ishii et al, 1992). The lherzolites within the Tasse property contain rather restricted Mg-numbers (90). The dunite sample from the Tasse location has the highest Mg-number (92) indicating a larger degree of partial melting from the initial fertile source (Fig. 14). The semi-quantitative model produced by Ishiwatari (1985), using Mg-numbers and major element oxides (wt.\%) illustrates the relative degrees of melting in ultramafic rocks. When the 
641 Tasse samples are plotted, it shows that the lherzolites have undergone $10-15 \%$ partial melting,

642 while the dunite sample resembles those for forearc dunite and harzburgites (see Ishii et al., 643 1992), which indicate higher degrees of partial melting, 25-30\% (Fig. 14). The 10-15\% degrees 644 of partial melting are consistent with the Peslier et al. (2002) model for Cr-diopside bearing 645 lherzolites from other localities within British Columbia.

646 Th-REE-LILE-HFSE (e.g., $\mathrm{Th} / \mathrm{Yb}, \mathrm{Th} / \mathrm{Nb}, \mathrm{La} / \mathrm{Nb}, \mathrm{La} / \mathrm{Sm}$ ) ratios are commonly used to 647 assess the subduction zone geochemistry, given that Th, LREE and LILE tend to be mobilized 648 whereas HFSE are predominantly immobile during slab-dehydration processes (Pearce and 649 Parkinson, 1993; Pearce and Peate, 1995; Zack and John, 2007; Pearce, 2008, 2014; König et al., 650 2010; Shervais and Jean, 2012). Chondritic values of coupled HFSE ratios, such as $\mathrm{Nb} / \mathrm{Ta}$ and $651 \mathrm{Zr} / \mathrm{Hf}$, have been used for assessing source characteristics and petrogenetic processes (Jochum et 652 al., 1989). The mantle xenoliths sampled during this study show subchondritic to superchondritic 653 values for $\mathrm{Y} / \mathrm{Ho}$ and $\mathrm{Nb} / \mathrm{Ta}$, while $\mathrm{Zr} / \mathrm{Hf}$ chondritic values tend to be superchondritic (Fig. 8; 654 Table 1). The spread seen in $\mathrm{Zr} / \mathrm{Hf}$ and $\mathrm{Nb} / \mathrm{Ta}$ may in part be due to metasomatic processes, 655 fractionation effects or an increase in element mobility.

656 It is common for $\mathrm{Nb}$ and $\mathrm{Ta}$ to substitute into a Ti-bearing phase, such as rutile or ilmenite 657 (see Stolz et al., 1996; Plank, 2005; König et al., 2010; Hui et al., 2011), resulting in depletion of 658 these elements relative to Th, LREE and LILE. The mantle xenoliths do not show any abundance 659 of such phases, which suggests that the Ti-bearing phases may have been retained in the 660 subduction slab. The enrichment of $\mathrm{Th}$ and La relative to $\mathrm{Nb}$ and $\mathrm{Ta}$ by rutile-saturated melts can 661 also generate negative $\mathrm{Nb}$-Ta anomalies as seen in the Tasse xenoliths (see Plank, 2005; König et 662 al., 2010). Island arc rocks are commonly depleted in HFSE, although not necessarily Zr and Hf 663 (see Saunders et al. 1991; Pearce and Peate, 1995). The Sr/Nd values (15 \pm 8 ) of the Tasse suite 
664 are similar to global averages $(15 \pm 5)$ of other peridotites (Jochum et al., 1989). Island arc basalts

665 have elevated $\mathrm{Sr} / \mathrm{Nd}(30-35)$ (Jochum et al., 1989). The $\mathrm{Sr} / \mathrm{Nd}$ values seen in the Tasse suite are 666 more characteristic of MORBs (10-15) and OIBs (14-22).

667 The LREE-enriched characteristics of some of the Tasse mantle xenoliths are variable from 668 slight to more strongly enriched samples (Fig. 9). This has also been seen in lherzolite, dunite 669 and harzburgite xenoliths throughout southeastern British Columbia (Brearley and Scarfe, 1984; 670 Brearley et al., 1984; Sun and Kerrich, 1995; Peslier et al., 2002; Greenfield et al., 2013), 671 indicating that metasomatism has likely been prevalent throughout the region.

The nature of the metasomatism is correlated with subduction and arc forming processes.

673 Common forms of metasomatism associated with these environments are typically slab 674 dehydration and melt percolation. The Tasse xenoliths do not contain any hydrous mineral 675 phases, as seen in forearc peridotites (see Ishii et al., 1992; Pearce et al., 1992; Parkinson and 676 Pearce, 1998; Pearce et al., 2000; Hyndman and Peacock, 2003; Ishizuka et al., 2014), 677 commonly associated with serpentinization. One such study, noted earlier by Brearley and Scarfe 678 (1984), did find minor amounts of amphibole in one spinel lherzolite from British Columbia, but 679 it is not commonly present throughout suites of xenoliths studied within British Columbia. It 680 does not appear that hydrous metasomatism is prevalent within the subcontinental lithosphere 681 throughout a large extent beneath British Columbia. Numerous studies have attributed mantle metasomatism to silicate and carbonatite melt 683 percolation and interaction with peridotites (see Yaxley et al., 1998; Coltorti et al. 1999; Litasov 684 et al., 2000; Downes, 2001; Dixon et al., 2008; Maruyama et al., 2009; Martin et al., 2014). 685 Coltorti et al. (1999) suggested that carbonatite melt metasomatism results in strong LREE 686 enrichments $\left(\mathrm{La} / \mathrm{Yb}_{\mathrm{cn}}>3-4\right)$ and various $\mathrm{Ti}$ and $\mathrm{Zr}$ negative anomalies compared to alkaline- 
687 silicate metasomatism. The LREE enrichment, and positive $\mathrm{Zr}$ and negative Ti anomalies in the 688 Tasse xenoliths (Figs. 9 and 10) likely reflect carbonatite- or alkaline-melt metasomatism. 689 Although, no petrographic evidence of secondary carbonate phases has been recognized in the 690 Tasse xenoliths, clinopyroxene resorption texture (Fig. 5 e-f) might reflect the effect of carbonate 691 metasomatism. However, geochemical evidence: (1) $\mathrm{La} / \mathrm{Yb}_{\mathrm{cn}}<4$; (2) $\mathrm{Ti} / \mathrm{Eu}>3000$; (3) positive $692 \mathrm{Zr}$ anomalies are consistent with alkalic-silicate metasomatism rather than carbonate-melt 693 metasomatism (Fig. 15) (Coltorti et al. 1999). Clinopyroxene and spinel in the Tasse mantle 694 xenoliths might have formed at the expense of Al-rich orthopyroxene during alkalic-silicate melt 695 peridotite interaction (cf., Kepezhinskas et al., 1995; Coltorti et al., 1999). The alkali-silicate 696 melt metasomatism may in part be related to the percolation of host alkaline basaltic melts. 697 Although the alkaline basaltic rocks only erupted to the surface recently in the Cenozoic 698 (Littlejohn and Greenwood, 1974; Brearley and Scarfe, 1984; Brearley et al., 1984; Sun and 699 Kerrich, 1995; Peslier et al., 2002; Greenfield et al., 2013; Kuehn et al., 2015), the melts may 700 have percolated through the mantle for extended periods of time prior to the eruption of the 701 alkaline basalts.

702 Re-Os studies of mantle xenoliths in British Columbia by Peslier et al. (2000a, b) have 703 demonstrated that the lithospheric mantle beneath the Omineca and Intermontane belts is likely 704 Precambrian in age. Specifically, the Os isotopic signature of the lherzolites indicates partial 705 melting of the mantle during intervals in the late Mesoproterozoic, broadly at the time of 706 Grenville orogenesis in eastern and southern North America. This interpretation implies 707 continuation of North American subcontinental lithospheric mantle below a large swath of the 708 accreted terranes (Peslier et al., 2000a, b) and is consistent with seismic interpretations that show 709 westward continuation of North American crust under the Omineca and Intermontane belts 
710 (Cook et al., 2004). The Re-Os results are also consistent with an emerging realization of modest 711 Grenville-age activity that extends in a belt from the northern Canadian Cordillera to the 712 northwestern conterminous United States (Milidragovic et al. 2011). The interpretation of 713 metasomatic activity in the mantle of the Canadian Cordillera is supported by the studies of 714 Brearley and Scarfe (1984), Brearley et al. (1984) and Sun and Kerrich (1995). Our findings also 715 suggest that the mantle has undergone various events of partial melting and metasomatism (Figs. 716 13-15). We are unable to determine if the melting and metasomatism in the Tasse suite occurred 717 during the Precambrian or Phanerozoic, using our current set of data.

718 Studies of the Lherz massif have shown evidence regarding refertilization of refractory 719 peridotites (harzburgites) producing secondary lherzolites (Le Roux et al., 2007). The formation 720 of the secondary lherzolites was shown by detailed structural mapping and geochemical analysis. 721 Reaction textures at harzburgite-lherzolite contacts suggest refertilization of harzburgite by 722 upwelling asthenospheric partial melts. Our study indicates that melt metasomatism played an 723 important role in the origin of LREE- and LILE-enriched patterns by refertilizing numerous 724 sections of previously depleted lithospheric mantle. This enrichment process is not specific to 725 lherzolites, as harzburgites from British Columbia have also shown metasomatic enrichment 726 (Peslier et al., 2002). Additional petrographic and geochemical studies of mantle xenoliths in 727 southeast British Columbia are needed to better understand the possible refertilization of the 728 mantle and secondary lherzolite formation, as seen in the Lherz massif.

\section{Conclusions}


On the basis of new field observations, SEM analyses, and whole-rock major and trace

733

734 735

736

element and $\mathrm{Sr}-\mathrm{Nd}-\mathrm{Pb}$ isotope data, the following petrologic and geodynamic conclusions are drawn for the Tasse alkaline basalts and mantle xenoliths.

1. Distinct geochemical characteristics of the spinel peridotites analyzed for this study, as well as studies conducted by other researchers (e.g., Peslier et al., 2002; Francis et al., 2010; Kuehn et al., 2015) in southern British Columbia provide evidence for upper mantle heterogeneity. The presence of lherzolites, harzburgites and dunites throughout the Omineca and Intermontane belts (Supplementary Fig. 1) demonstrate varying degrees of partial melting and metasomatism generating upper mantle heterogeneity. Tasse spinel lherzolites represent residues of $10-15 \%$ partial melt depletion and $20-25 \%$ partial melt depletion for the dunite sample.

2. The Tasse xenoliths exhibit three distinctive REE patterns reflecting various degrees of metasomatic enrichment in a pre-Miocene sub-arc mantle wedge: (1) Group 1 is characterized by concave-upward LREE patterns; (2) Group 2 displays flat to moderately LREE enriched patterns; and (3) Group 3 is strongly LREE enriched. Two outlier samples exhibit unique patterns indicating further variable degrees of metasomatism. Metasomatism in the source of the xenoliths is cryptic and appears to have stemmed from percolating alkaline-silicate melts. All xenolith samples share positive $\mathrm{Th}, \mathrm{Rb} \mathrm{K}, \mathrm{Pb}$ and $\mathrm{Zr}$ ( $\mathrm{Hf}$ ) anomalies and negative $\mathrm{Nb}(\mathrm{Ta})$ and $\mathrm{Ti}$ anomalies on MORB-normalized trace element diagrams, which is consistent with the formation of the subcontinental lithospheric mantle beneath southern British Columbia above subducted oceanic slabs. 
754 3. The Tasse alkaline basalts are uniform in composition and originated from a well755 homogenized asthenospheric mantle source. The alkaline nature $\left(\mathrm{K}_{2} \mathrm{O}+\mathrm{Na}_{2} \mathrm{O}=5.1-6.6\right.$

756

757

758

759

760

761

762

763

764

765

766

767

768

769

770

771

772

773

774

775

776 wt.\%), $\mathrm{Nb} / \mathrm{Y}(2.6-3.0)$ and $\mathrm{Zr} / \mathrm{Y}(13-14)$ are consistent with an incompatible-element enriched source originating from the garnet stability field.

4. The alkaline basalts have large positive $\varepsilon N d(+3.8$ to +5.5$)$ values and 338-426 Ma depleted mantle model ages, suggesting a minimal magma-crust interaction and mantle melting events between the Silurian to Carboniferous. They display narrow ranges of $\mathrm{Sr}$ $\left({ }^{87} \mathrm{Sr} /{ }^{86} \mathrm{Sr}=0.703346-0.703591\right)$ and $\mathrm{Pb}\left({ }^{206} \mathrm{~Pb} /{ }^{204} \mathrm{~Pb}=19.40-19.58 ;{ }^{207} \mathrm{~Pb} /{ }^{204} \mathrm{~Pb}=15.57-15.60 ;\right.$ $\left.{ }^{208} \mathrm{~Pb} /{ }^{204} \mathrm{~Pb}=38.99-39.14\right)$ isotopic ratios, consistent with a homogeneous mantle source. The Tasse basalts are isotopically distinct from continental flood basalts and subductionrelated basalts, plotting mainly in the ocean island basalt (OIB) field on $\mathrm{Sr}-\mathrm{Nd}-\mathrm{Pb}$ isotope ratio diagrams.

5. The Neogene intraplate volcanic field was generated by a combination of diffuse mantle upflow through the Northern Cordilleran Slab Window, localized lithospheric extension, slab-induced "back arc" mantle circulation, possible plume activity and localized delamination of cratonic lithospheric mantle.

\section{Acknowledgements}

This study was supported through an NSERC-Engage grant (NSERC/EGP/433818-2012) to Polat and an NSERC Discovery Grant to Thorkelson. Field work was supported by Barker

Minerals Ltd. Incisive comments by John Greenough and an anonymous reviewer led to significant improvements of the manuscript. 
777

778

779

780

781

782

783

784

785

786

787

788

789

790

791

792

793

794

795

796

797

798

799

\section{References}

Abraham, A.C., Francis, D., Polvé, M., 2005. Origin of Recent alkaline lavas by lithospheric thinning beneath the northern Canadian Cordillera. Canadian Journal of Earth Sciences 42, 1073-1095.

Anonymous, 1972. Penrose field conference on ophiolites. Geotimes 17, 24-25.

Arai, S., Abe, N., Ishimaru, S., 2007. Mantle peridotites from the Western Pacific. Gondwana Research 11, 180-199.

Artemieva, I., 2011. The Lithosphere: An Interdisciplinary Approach. Cambridge University Press, Cambridge, pp. 794.

Audet, P., Bostock, M. G., Mercier, J.-P., Cassidy, J. F., 2008. Morphology of the Explorer-Juan de Fuca slab edge in northern Cascadia: Imaging plate capture at a ridge-trench-transform triple junction. Geology 36, 895-898.

Bailey, D.K., 1972. Uplift, rifting and magmatism in continental plates. Journal of Earth Sciences 8, 225-239.

Bailey, D.K., 1982. Mantle metasomatism; continuing chemical change within the Earth. Nature, 296, 525-530.

Ballhaus, C., 1993. Redox states of lithospheric and asthenospheric upper mantle. Contributions to Mineralogy and Petrology 114, 331-348.

Bao, X., Eaton, D.W., Guest, B., 2014. Plateau uplift in western Canada caused by lithospheric delamination along a craton edge. Nature Geoscience 7, 830-833.

Barker Minerals Ltd. (http://www.barkerminerals.com)

Barnes, S.J., Roeder, P.L., 2001. The range of spinel compositions in terrestrial mafic and ultramafic rocks. Journal of Petrology 42, 2279-2302. 
Beccaluva, L., Coltorti, M., Giunta, G., Siena, F., 2004. Tethyan vs. Cordilleran ophiolites: a reappraisal of distinctive tectono-magmatic features of supra-subduction complexes in relation to the subduction mode. Tectonophysics 393, 163-174.

Bennett, V.C., 2003. Compositional Evolution of the Mantle. In: Treatise on Geochemistry, Volume 2: The Mantle and Core, Carlson, R.W. (ed.), Elsevier, Pergamon, Oxford, pp. 493519.

Bevier, M.L., Armstrong, R.L., Souther, J.G., 1979. Miocene peralkaline volcanism in westcentral British Columbia - Its temporal and plate-tectonics setting. Geology 7, 389-392.

Bodinier, J-L., Godard, M., 2003. Orogenic, Ophiolitic, and Abyssal Peridotites. In: Treatise on Geochemistry, Volume 2: The Mantle and Core, Carlson, R.W. (ed.), Elsevier, Pergamon, Oxford, pp. 61-102.

Brearley, M., Scarfe, C.M., 1984. Amphibole in a spinel lherzolite xenolith: evidence for volatiles and partial melting in the upper mantle beneath southern British Columbia. Canadian Journal of Earth Sciences 21, 1067-1072.

Brearley, M., Scarfe, C.M., Fujii, T., 1984. The petrology of ultramafic xenoliths from Summit Lake, near Prince George, British Columbia. Contributions to Mineralogy and Petrology 88, 53-63.

Breitsprecher, K., Thorkelson, D.J., Groome, W.G., 2003. Geochemical confirmation of the Kula-Farallon slab window beneath the Pacific Northwest in Eocene time. Geology 31, 351354. 
820

821

822

823

824

825

826

827

828

829

830

831

832

833

834

835

836

837

838

839

840

841

Burnham, O.M., Hechler, J.H., Semenyna, L., Schweyer, J., 2002. Summary of Field Work and Other Activities 2002; Ontario Geological Survey Open File Report 6100. Baker, C.L., Debicki, E.J., Kelly, R.I. and Parker, J.R. (Eds.), Sudbury, Ontario, 36-1-36-12.

Camp, V.E., Hanan, B.B., 2008. A plume-triggered delamination origin for the Columbia River Basalt Group. Geosphere 4, 480-495.

Camp, V.E., Ross, M.E., Duncan, R.A., Jarboe, N.A., Coe, R.S., Hanan, B.B., Johnson, J.A., 2013. The Steens Basalt: Earliest lavas of the Columbia River Basalt Group. In: The Columbia River Flood Basalt Province, Special Paper 497. Reidel, S.P., Camp, V.E., Ross, M.E., Wolff, J.A., Martin, B.S., Tolan, T.L., and Wells, R.E. (Eds.), Geological Society of America, pp. 87-116.

Canil, D., Lee, C.-T., 2009. Were deep cratonic mantle roots hydrated in Archean oceans? Geology 37, 667-670.

Carr, S.D., 1995. The southern Omineca Belt, British Columbia: new perspectives from the Lithoprobe Geoscience Program. Canadian Journal of Earth Sciences 32, 1720-1739.

Chen, Y., Zhang, Y., Graham, D., Su, S., Deng, J., 2007. Geochemistry of Cenozoic basalts and mantle xenoliths in Northeast China. Lithos 96, 108-126.

Chen, M.M., Tian, W., Suzuki, K., Tejada, M.-L.-G. , Liu, F.L., Senda, R., Wei, C.J., Chen, B., Chu, Z.Y., 2014. Peridotite and pyroxenite xenoliths from Tarim, NW China: Evidences for melt depletion and mantle refertilization in the mantle source region of the Tarim flood basalt. Lithos 204, 97-111.

Chin, E.J., Lee, C-T.A., Luffi, P., and Tice, M., 2012. Deep Lithospheric Thickening and Refertilization beneath Continental Arcs: Case Study of the P, T and Compositional 

53, 477-511.

844 845

846

847 848

Chu, Z.-Y., Wu, F.-Y., Walker, R.J., Rudnick, R.L., Pitcher, L., Puchtel, I.S., Yang, Y.-H., Wilde, S.A., 2009. Temporal Evolution of the Lithospheric Mantle beneath the Eastern North China Craton. Journal of Petrology 50, 1857-1898.

Colgan, J.P., Dumitru, T.A., McWilliams, M., Miller, E.L., 2006. Timing of Cenozoic volcanism and Basin and Range extension in northwestern Nevada: New constraints from the northern Pine Forest Range. GSA Bulletin 118, 126-139.

Coltorti, M., Bonadiman, C., Hinton, R. W., Siena, F., Upton, B. G. J., 1999. Carbonatite Metasomatism of the Oceanic Upper Mantle: Evidence from Clinopyroxenes and Glasses in Ultramafic Xenoliths of Grande Comore, Indian Ocean. Journal of Petrology 40, 133-165.

Condie, K.C., 2000. Episodic continental growth models: afterthoughts and extensions. Tectonophysics 322, 153-162.

Coney, P.J., Jones, D.L., Monger, J.W.H., 1980. Cordilleran suspect terranes. Nature 288, 329333.

Cook, F.A., Clowes, R.M., Snyder, D.B. van der Velden, A.J., Hall, K.W., Erdmer, P., Evenchick, C.A., 2004. Precambrian crust beneath the Mesozoic northern Canadian Cordillera discovered by Lithoprobe seismic reflection profiling. Tectonics 23, 1-28.

Currie, C.A., Hyndman, R.D., 2006. The thermal structure of subduction zone back arcs. Journal of Geophysical Research 111, 1-22.

Dantas, C., Grégoire, M., Koester, E., Conceição, R.V., Rieck Jr., N., 2009. The lherzolitewebsterite xenolith suite from Northern Patagonia (Argentina): Evidence of mantle-melt reaction processes. Lithos 107, 107-120. 
872

873

874 875

876

877

878

879 880

881

De Hoog, J.C. M., Gall, L., Cornell, D.H., 2010. Trace-element geochemistry of mantle olivine and application to mantle petrogenesis and geothermobarometry. Chemical Geology 270, 196-215.

DePaolo, D.J., 1981. Neodymium isotope geochemistry: An introduction. New York, SpringerVerlag, pp. 187.

Dilek, Y., Furnes, H. 2011. Ophiolite genesis and global tectonics: Geochemical and tectonic fingerprinting of ancient oceanic lithosphere. Geological Society of America Bulletin 123, $387-411$.

Dilek, Y., Furnes, H., 2014. Ophiolites and Their Origins. Elements 10, 93-100.

Dixon, J., Clague, D.A., Cousens, B., Monsalve, M.L., Uhl, J., 2008. Carbonatite and silicate melt metasomatism of the mantle surrounding the Hawaiian plume: Evidence from volatiles, trace elements, and radiogenic isotopes in rejuvenated-stage lavas from Niihau, Hawaii. Geochemistry, Geophysics, Geosystems 9, 1-34.

Downes, H., 2001. Formation and modification of the shallow sub-continental lithospheric mantle: a review of geochemical evidence from ultramafic xenolith suites and tectonically emplaced ultramafic massifs of western and central Europe. Journal of Petrology 42, 233250.

Downes, H., de Vries, C., Wittig, N., 2014. Hf-Zr anomalies in clinopyroxene from mantle xenoliths from France and Poland: implications for $\mathrm{Lu}-\mathrm{Hf}$ dating of spinel peridotite lithospheric mantle. International Journal of Earth Sciences 104, 89-102.

Edwards, B.R., Russell, J.K., 2000. Distribution, nature, and origin of Neogene-Quaternary magmatism in the northern Cordilleran volcanic province, Canada. GSA Bulletin 112, $1280-1295$. 
Ewing, T.E., 1980. Paleogene Tectonic Evolution of the Pacific Northwest. The Journal of Geology 88, 619-638.

Eyles, N., Miall, A., 2007. Chapter 8: Building Western Canada. Canada Rocks: The Geologic Journey. Fitzhenry and Whiteside, Markham, ON.

Eyuboglu, Y., Bektas, O., Pul, D., 2007. Mid-Cretaceous Olistostromal Ophiolitic Mélange Developed in the Back-arc Basin of the Eastern Pontide Magmatic Arc, Northeast Turkey. International Geology Review 49, 1103-1126.

Ferri, F., Höy, T., and Friedman, R.M., 1999. Description, U-Pb age and Tectonic Setting of the Quesnel Lake Gneiss, East-central British Columbia. Geological Fieldwork 1998 Report, British Columbia Ministry of Energy and Mines, Victoria, British Columbia, pp. 69-80.

Ferri, F., O’Brien, B.H., 2002. Preliminary Geology of the Cariboo Lake Area, Central British Columbia (093A/11, 12, 13 AND 14). Geological Fieldwork 2001 Report, British Columbia Ministry of Energy and Mines, Victoria, British Columbia, pp. 59-82.

Ferri, F., Schiarizza, P., 2006. Reinterpretation of the Snowshoe Group stratigraphy across a southwest-verging nappe structure and its implications for regional correlations within the Kootenay terrane. In Paleozoic Evolution and Metallogeny of Pericratonic Terranes at the Ancient Pacific Margin of North America, Canadian and Alaskan Cordillera, Special Paper 45. Colpron, M. and Nelson, J. (eds.) Geological Association of Canada (GAC), St. John's, Newfoundland, Canada. pp. 415-432.

Francis, D., Minarik, W., Proenza, Y., Shi, L., 2010. An overview of the Canadian Cordilleran lithospheric mantle. Canadian Journal of Earth Sciences 47, 353-368. 
Frederiksen, A.W., Bostock, M.G., VanDecar, J.C., Cassidy, J.F., 1998. Seismic structure of the upper mantle beneath the northern Canadian Cordillera from teleseismic travel-time inversion. Tectonophysics 294, 43-55.

Frei, R., Polat, A., 2013. Chromium isotope fractionation during oxidative weathering implications from the study of a Paleoproterozoic (ca. 1.9 Ga) paleosol, Schreiber Beach, Ontario, Canada. Precambrian Research 224, 434-453.

Fretzdorff, S., Livermore, R.A., Devey, C.W., Leat, P.T., Stoffers, P., 2002. Petrogenesis of the Back-arc East Scotia Ridge, South Atlantic Ocean. Journal of Petrology 43, 1435-1467.

Furnes, H., de Wit, M., and Dilek, Y., 2014. Four billion years of ophiolites reveal secular trends in oceanic crust formation. Geoscience Frontiers 5, 571-603.

Furnes, H., Dilek, Y., de Wit, M., 2015. Precambrian greenstone sequences represent different ophiolite types. Gondwana Research 27, 649-685.

Gabrielse, H., Monger, J.W.H., Wheeler, J.O., Yorath, C.J., 1991. Morphogeological belts, tectonic assemblages and terranes. In: Gabrielse, H., Yorath, C.J. (Eds.), Geology of the Cordilleran Orogen in Canada, Geology of Canada no. 4, Chapter 2, Part A, Geological Survey of Canada. Ottawa, Canada, 15-28.

Gast, P.W., All.g re, C.J., Hart, S.R., 1978. Trace elements in igneous petrology: a volume in memory of Paul W. Gast. Elsevier Science Publishing Company, Amsterdam.

Greenfield, A.M.R., Ghent, E.D., Russell, J.K., 2013. Geothermobarometry of spinel peridotites from southern British Columbia: implications for the thermal conditions in the upper mantle. Canadian Journal of Earth Sciences 50, 1019-1032. 
Grégoire, M., Langlade, J.A., Delpech, G., Dantas, C., Ceuleneer, G., 2009. Nature and evolution of the lithospheric mantle beneath the passive margin of East Oman: Evidence from mantle xenoliths sampled by Cenozoic alkaline lavas. Lithos 112, 203-216.

Guarnieri, L., Nakamura, E., Piccardo, G.B., Sakaguchi, C., Shimizu, N., Vannucci, R., Zanetti, A., 2012. Petrology, Trace Element and Sr, Nd, Hf Isotope Geochemistry of the North Lanzo Peridotite Massif (Western Alps, Italy). Journal of Petrology 53, 2259-2306.

Hanghøj, K., Kelemen, P.B., Hassler, D., Godard, M., 2010. Composition and Genesis of Depleted Mantle Peridotites from the Wadi Tayin Massif, Oman Ophiolite; Major and Trace Element Geochemistry, and Os Isotope and PGE Systematics. Journal of Petrology 51, 201227.

Harder, M., Russell, J.K., 2006. Thermal state of the upper mantle beneath the Northern Cordilleran Volcanic Province (NCVP), British Columbia, Canada. Lithos 87, 1-22.

Hart, C., 1999. The Geological Framework of the Yukon Territory. Department of Energy, Mines and Resources, Yukon Geological Survey, http://www.geology.gov.yk.ca/pdf/bedrock_geology.pdf.

Hidas, K., Guzmics, T., Szabó, C., Kovács, I., Bodnar, R.J., Zajacz, Z., Nédli, Z., Vaccari, L., Perucchi, A., 2010. Coexisting silicate melt inclusions and H2O-bearing, CO2-rich fluid inclusions in mantle peridotite xenoliths from the Carpathian-Pannonian region (central Hungary). Chemical Geology 274, 1-18.

Hofmann, A.W., 1997. Mantle geochemistry: the message from oceanic volcanism. Nature 385: 219-229. 
Holm, P.M., Søager, N., Dyhr, C.T., Nielsen, M.R., 2014. Enrichments of the mantle sources beneath the Southern Volcanic Zone (Andes) by fluids and melts derived from abraded upper continental crust. Contributions to Mineralogy and Petrology 167, 1-27.

Horwitz, E.P., Chiarizia, R., Dietz, M.L., 1992. A novel strontium-selective extraction chromatographic resin. Solvent Extraction and Ion Exchange 10, 313-36.

Hui, H., Niu, Y., Zhidan, Z., Huixin, H., Dicheng, Z., 2011. On the Enigma of Nb-Ta and Zr-Hf Fractionation - A Critical Review. Journal of Earth Science 22, 52-66.

Hyndman, R.D., Peacock, S.M., 2003. Serpentinization of the forearc mantle. Earth and Planetary Science Letters 212, 417-432.

Hyndman, R.D., Currie, C.A., Mazzotti, S., Frederiksen, A., 2009. Temperature control of continental lithosphere elastic thickness, Te vs Vs. Earth and Planetary Science Letters 277, 539-548.

Ionov, D.A., Chazot, G., Chauvel, C., Merlet, C., Bodinier, J.-L., 2006. Trace element distribution in peridotite xenoliths from Tok, SE Siberian craton: A record of pervasive, multi-stage metasomatism in shallow refractory mantle. Geochimica et Cosmochimica Acta $70,1231-1260$.

Ishii, T., Robinson, P.T., Maekawa, H. Fiske, R., 1992. Petrological studies of peridotites from diapiric serpentinite seamounts in the Izu-Ogasawara-Mariana Forearc, Leg 125. Proceedings of the Ocean Drilling Program, Scientific Results 125, 445-485.

Ishiwatari, A., 1985. Igneous Petrogenesis of the Yakuno Ophiolite (Japan) in the context of the diversity of ophiolites. Contributions to Mineralogy and Petrology 89, 155-167.

Ishizuka, O., Tani, K., Reagan, M.K., 2014. Izu-Bonin-Mariana Forearc Crust as a Modern Ophiolite Analogue. Elements 10, 115-120. 
974 Jochum, K.P., McDonough, W.F., Palme, H. Spettel, B., 1989. Compositional constraints on the 975 continental lithospheric mantle from trace elements in spinel peridotite xenoliths. Nature $976 \quad 340,548-550$.

977 Johnston, S.T., 2001. The Great Alaskan Terrane Wreck: reconciliation of paleomagnetic and 978 geological data in the northern Cordillera. Earth and Planetary Science Letters 193, 259-272.

979 Kamgang, P., Chazot, G., Emmanuel, N., Tchoua, F.M., 2008. Geochemistry and geochronology 980 of mafic rocks from Bamenda Mountains (Cameroon): Source composition and crustal contamination along the Cameroon Volcanic Line. Comptes Rendus Geoscience, 340, 850857.

Kay, R.W., Gast, P.W., 1973. The rare earth content and origin of alkali-rich basalts. Journal of 984 Geology 81, 653-682.

985

Kepezhinskas, P.K., Defant, M.J., Drummond, M.S., 1995. Na Metasomatism in the Island-Arc 986 987 Mantle by Slab Melt-Peridotite Interaction: Evidence from Mantle Xenoliths in the North Kamchatka Arc. Journal of Petrology 36, 1505-1527.

Kerrich, R., Wyman, D., Hollings, P., Polat, A.1999. Variability of Nb/U and Th/La in 3.0 to 2.7 Ga Superior Province ocean plateau basalts: implications for the timing of continental growth and lithosphere recycling. Earth and Planetary Science Letters 168, 101-115.

Khedr, M.Z., Arai, S., Python, M., Tamura, A. 2014. Chemical variations of abyssal peridotites

Kheirkhah, M., Neill, I., Allen, M.B., 2015. Petrogenesis of OIB-like basaltic volcanic rocks in a 995 continental collision zone: Late Cenozoic magmatism of Eastern Iran. Journal of Asian 996 Earth Sciences 106, 19-33. 
König, S., Münker, C., Schuth, S., Luguet, A., Hoffmann, J.E., Kuduon, J., 2010. Boninites as windows into trace element mobility in subduction zones. Geochimica et Cosmochimica Acta 74, 684-704.

König, S., Münker, C., Schuth, S., Garbe-Schönberg, D., 2008. Mobility of tungsten in subduction zones. Earth and Planetary Science Letters 274, 82-92.

Kuehn, C., Guest, B., Russel, J.K., Benowitz, J.A., 2015. The Satah Mountain and Baldface Mountain volcanic fields: Pleistocene hot spot volcanismin the Anahim Volcanic Belt, westcentral British Columbia, Canada. Bulletin of Volcanology 77, 3-27.

Kuritani, T., Yokoyama, T., Nakamura, E., 2008. Generation of Rear-arc Magmas Induced by Influx of Slab-derived Supercritical Liquids: Implications from Alkali Basalt Lavas from Rishiri Volcano, Kurile Arc. Journal of Petrology 49, 1319-1342.

Kusky, T., 2004. Epilogue: What if anything have we learned about Precambrian ophiolites and early Earth processes? In Precambrian Ophiolites and Related Rocks, Developments in Precambrian Geology, Volume 13, Kusky, T. (ed.) and Condie, K.C. (Series ed.), Elsevier, Amsterdam, pp. 727-737.

Le Roux, V., Bodinier, J.-L., Tommasi, A., Alard, O., Dautria, J.-M., Vauchez, A., Riches, A.J.V., 2007. The Lherz spinel lherzolite: Refertilized rather than pristine mantle. Earth and Planetary Science Letters 259, 599-612.

Li, H-Y., Huang, X-L., Guo, H., 2014. Geochemistry of Cenozoic basalts from the Bohai Bay Basin: Implications for a heterogeneous mantle source and lithospheric evolution beneath the eastern North China Craton. Lithos 196-197, 54-66.

Litasov K.D., Foley S.F., Litasov Y.D., 2000. Magmatic modification and metasomatism of the subcontinental mantle beneath the Vitim volcanic field (East Siberia): evidence from trace 
element data on pyroxenite and peridotite xenoliths from Miocene picrobasalt. Lithos 54, 83-114.

1022 Littlejohn, A.L., Greenwood, H.J., 1974. Lherzolite Nodules in Basalts from British Columbia, 1023 Canada. Canadian Journal of Earth Sciences 11, 1288-1308.

1024 Liu, J., Carlson, R.W., Rudnick, R.L., Walker, R.J., Gao, S., Wu, F-Y., 2012. Comparative Sr1025 Nd-Hf-Os-Pb isotope systematics of xenolithic peridotites from Yangyuan, North China 1026 Craton: Additional evidence for a Paleoproterozoic age. Chemical Geology 332-333, 1-14.

1027 Lu, J., Zheng, J., Griffin, W.L., Yu, C., 2013. Petrology and geochemistry of peridotite xenoliths 1028 from the Lianshan region: Nature and evolution of lithospheric mantle beneath the lower $1029 \quad$ Yangtze block. Gondwana Research 23, 161-175.

1030 Madsen, J.K., Thorkelson, D.J., Friedman, R.M., Marshall D.D., 2006. Cenozoic to Recent plate 1031 configurations in the Pacific Basin: Ridge subduction and slab window magmatism in 1032 western North America. Geosphere 2, 11-34.

1033 Manthei, C.D., Ducea, M.N., Girardi, J.D., Patchett, P.J. Gehrels, G.E., 2010. Isotopic and 1034 geochemical evidence for a recent transition in mantle chemistry beneath the western 1035 Canadian Cordillera. Journal of Geophysical Research 115, 1-19.

1036 Martin, A.P., Price, R.C., Cooper, A.F., 2014. Constraints on the composition, source and 1037 petrogenesis of plagioclase-bearing mantle peridotite. Earth-Science Reviews 138, 89-101.

1038 Maruyama, S., Hasegawa, A., Santosh, M., Kogiso, T., Omori, S., Nakamura, H., Kawai, K., 1039 Zhao, D., 2009. The dynamics of big mantle wedge, magma factory and metamorphic1040 metasomatic factory in subduction zones. Gondwana Research 16, 414-430.

1041 Maury, R.C., Defant, M.J., Joron, J-L., 1992. Metasomatism of the sub-arc mantle inferred from 1042 trace elements in Philippine xenoliths. Nature 360, 661-663. 
1043 McCulloch, M.T., 1993. The role of subducted slabs in an evolving Earth. Earth and Planetary 1044 Science Letters 115, 89-100.

1045 McCulloch, M.T., Bennett, V.C., 1994. Progressive growth of the Earth's continental crust and 1046 depleted mantle: Geochemical constraints. Geochimica et Cosmochimica Acta 58, 4717$1047 \quad 4738$.

1048 McDonough, W.F., Sun, S.-S., 1995. The composition of the Earth. Chemical Geology, 120: 1049 223-253.

1050 Menzies, M.A., Fan, W., Zhang, M., 1993. Palaeozoic and Cenozoic lithoprobe and the loss of $1051>120 \mathrm{~km}$ of Archean lithosphere, Sino-Korean craton, China. In Magmatic Processes and 1052 Plate Tectonics, Special Publication 76, Prichard, H.M., Alabaster, T., Harris, N.B.W., 1053 Neary, C.R. (eds.), Geological Society. pp. 71-81.

1054 1055

1056 1057 1058 1059 1060 1061 1062 1063 1064 1065

Mercier, J-C. C., Nicolas, A., 1975. Textures and Fabrics of Upper-Mantle Peridotites as Illustrated by Xenoliths from Basalts. Journal of Petrology 16, 454-487.

Mercier, J.-P., Bostock, M.G., Cassidy, J.F., Dueker, K., Gaherty, J.B., Garnero, E.J., Revenaugh, J., Zandt, G., 2009. Body-wave tomography of western Canada. Tectonophysics $475,480-492$.

Metcalf, R.V., Shervais, J.W., 2008. Suprasubduction-zone ophiolites: Is there really an ophiolite conundrum? In Ophiolites, Arcs, and Batholiths: A Tribute to Cliff Hopson, Special Paper 438, Wright, J.E. and Shervais, J.W. (eds.), Geological Society of America. pp. 191-222.

Milidragovic, D., Thorkelson, D.J., Davis, W.J., Marshall, D.D., Gibson, H.D., 2011. Evidence for late Mesoproterozoic tectonism in northern Yukon and the identification of a Grenvilleage tectonothermal belt in western Laurentia. Terra Nova 23, 307-313. 
1066 1067 1068 1069 1070 1071 1072 1073 1074 1075 1076 1077 1078 1079 1080 1081 1082 1083 1084 1085 1086 1087 1088

Monger, J., 2014. Seeking the Suture: The Coast-Cascade Conundrum. Geoscience Canada, 41: 379-398.

Monger, J., Price, R., 2002. The Canadian Cordillera: Geology and Tectonic Evolution. CSEG Recorder, Feb: 17-36.

Monger, J.W.H., Price, R.A., Tempelman-Kluit, D.J., 1982. Tectonic accretion and the origin of the two major metamorphic and plutonic welts in the Canadian Cordillera. Geology 10, 7075.

Mullen, E.K., Weis, D., 2013. Sr-Nd-Hf-Pb isotope and trace element evidence for the origin of alkalic basalts in the Garibaldi Belt, northern Cascade arc. Geochemistry, Geophysics, Geosystems 14, 3126-3155.

Nelson, J., Colpron, M., 2007. Tectonics and metallogeny of the British Columbia, Yukon and Alaskan Cordillera, 1.8 Ga to the present, in Goodfellow, W.D., ed., Mineral Deposits of Canada: A Synthesis of Major Deposit-Types, District Metallogeny, the Evolution of Geological Provinces, and Exploration Methods: Geological Association of Canada, Mineral Deposits Division, Special Publication 5, 755-791.

Nkouandou, O.F., Temdjim, R., 2011. Petrology of spinel lherzolite xenoliths and host basaltic lava from Ngao Voglar volcano, Adamawa Massif (Cameroon Volcanic Line, West Africa): equilibrium conditions and mantle characteristics. Journal of Geosciences 56, 375-387.

Parkinson, I.J., Pearce, J.A., 1998. Peridotites from the Izu-Bonin-Mariana Forearc (ODP Leg 125): Evidence for Mantle Melting and Melt-Mantle Interaction in a Supra-Subduction Zone Setting. Journal of Petrology 39, 1577-1618.

Parkinson, I.J., Arculus, R.J. and Eggins, S.M., 2003. Peridotite xenoliths from Grenada, Lesser Antilles Island Arc. Contributions to Mineralogy and Petrology 146, 241-262. 
Parrish, R., Carr, S.D., Parkinson, D.L., 1988, Eocene extensional tectonics and geochronology of the southern Omineca Belt, British Columbia and Washington, Tectonics 7, 181-212.

Pearce, J.A., 2008. Geochemical fingerprinting of oceanic basalts with applications to ophiolite classification and the search for Archean oceanic crust. Lithos 100, 14-48.

Pearce, J.A., 2014. Immobile Element Fingerprinting of Ophiolites. Elements 10, 101-108.

Pearce, J.A., Barker, P.F., Edwards, S.J., Parkinson, I.J., Leat, P.T., 2000. Geochemistry and tectonic significance of peridotites from the South Sandwich arc-basin system, South Atlantic. Contributions to Mineralogy and Petrology 139, 36-53.

Pearce, J.A., van der Laan, S.R., Arculus, R.J., Murton, B.J., Ishii, T., Peate, D.W., Parkinson, I.J., 1992. Boninite and harzburgite from Leg 125 (Bonin-Mariana forearc): A case study of magma genesis during the initial stages of subduction. Proceedings of the Ocean Drilling Program, Scientific Results 125, 623-659.

Pearce, J.A., Peate, D.W., 1995. Tectonic implications of the composition of volcanic arc magmas. Annual Review of Earth and Planetary Sciences 23, 251-285.

Pearce, J.A., Parkinson, I.J., 1993. Trace element models for mantle melting to volcanic arc petrogenesis. In: Prichard, H.M., Alabaster, T., Harris, N.B.W, Neary, C.R. (eds.), Magmatic Processes and Plate Tectonics. Geological Society Special Publication 76, 373403.

Pearce, J.A., Stern, R.J., 2006. Origin of Back-Arc Basin Magmas: Trace Element and Isotope Perspectives. In: Christie, D.M., Fisher, C.R., Lee, S-M., Givens, S., (eds.), Back-Arc Spreading Systems: Geological, Biological, Chemical, and Physical Interactions, American Geophysical Union, Washington, DC. pp. 63-86. 
1111 Peng, Z.X., Mahoney, J.J., Vanderkluysen, L., Hooper, P.R., 2014. Sr, Nd and Pb isotopic and 1112 chemical compositions of central Deccan Traps lavas and relation to southwestern Deccan 1113 stratigraphy. Journal of Asian Earth Sciences 84, 83-94.

1114 Peslier, A.H., Reisberg, L., Ludden, J., Francis, D., 2000a. Os isotopic systematics in mantle 1115 xenoliths; age constraints on the Canadian Cordillera lithosphere. Chemical Geology 166, $1116 \quad 85-101$.

1117 Peslier, A.H., Reisberg, L., Ludden, J., Francis, D., 2000b. Re-Os constraints on harzburgite and 1118 lherzolite formation in the lithospheric mantle: A study of Northern Canadian Cordillera 1119 xenoliths. Geochimica et Cosmochimica Acta 64, 3061-3071.

1120 Peslier, A.H., Francis, D., Ludden, J., 2002. The Lithospheric Mantle beneath Continental 1121 Margins: Melting and Melt-Rock Reaction in Canadian Cordillera Xenoliths. Journal of 1122 Petrology 43, 2013-2047.

1123 Plank, T., 2005. Constraints from Thorium/Lanthanum on Sediment Recycling at Subduction 1124 Zones and the Evolution of the Continents. Journal of Petrology 46, 921-944.

1125 Polat, A., Kerrich, R., Casey, J.F., 1997. Geochemistry of Quaternary basalts erupted along the 1126 East Anatolian and Dead Sea Fault zones of southern Turkey: implications for mantle 1127 sources. Lithos 40, 55-68.

1128 Preece, S.J., Hart, W.K., 2004. Geochemical variations in the <5 Ma Wrangell Volcanic Field, 1129 Alaska: implications for the magmatic and tectonic development of a complex continental $1130 \quad$ arc system. Tectonophysics 392, 165- 191.

1131 Price, R.A., 1994. Cordilleran tectonics and the evolution of the Western Canada sedimentary 1132 basin: In Chapter 2 of Geological Atlas of Western Canada, Mossop, G.D., Shetsen I. (eds.), 1133 Canadian Society of Petroleum Geologists, Calgary, Alberta, pp. 13-24. 
1134 Putirka, K., 1999. Melting depths and mantle heterogeneity beneath Hawaii and the East Pacific

1135 Rise: Constraints from Na/Ti and rare earth element ratios. Journal of Geophysical Research

$1136 \quad 104,2817-2829$.

1137 Putirka, K., Platt, B., 2012. Basin and Range volcanism as a passive response to extensional 1138 tectonics. Geosphere 8, 1274-1285.

1139 Ranalli, G., Brown, R.L., Bosdachin, R., 1989. A geodynamic model for extension in the 1140 Shuswap core complex, southeastern Canadian Cordillera. Canadian Journal of Earth $1141 \quad$ Sciences 26, 1647-1653.

1142 Riches, A.J.V., Rogers, N.W., 2011. Mineralogical and geochemical constraints on the shallow 1143 origin, ancient veining, and multi-stage modification of the Lherz peridotite. Geochimica et 1144 Cosmochimica Acta 75, 6160-6182.

1145 Rudnick, R.L., Gao, S, 2003. Composition of the continental crust. In: Rudnick, R.L. (ed.), 1146 Treatise on Geochemistry, Volume 3: The Crust, Elsevier. Pergamon, Oxford. pp. 1-64.

1147 Santosh, M., Shaji, E., Tsunogae, T., Ram Mohan, M., Satyanarayanan, M., Horie, K., 2013. 1148 Suprasubduction zone ophiolite from Agali hill: Petrology, zircon SHRIMP U-Pb 1149 geochronology, geochemistry and implications for Neoarchean plate tectonics in southern 1150 India. Precambrian Research 231, 301-324.

1151 Saunders, A.D., Norry, M.J. and Tarney, J., 1991. Fluid influence on the trace element 1152 compositions of subduction zone magmas. Philosophical Transactions of the Royal Society of London A. 335, 377-392.

1154 Şengör, A.M.C., Natal'in, B.A., 2004. Phanerozoic analogues of Archaean oceanic basement 1155 fragments: Altaid ophiolites and ophirags. In Precambrian Ophiolites and Related Rocks, 
Developments in Precambrian Geology, Vol. 13, Kusky, Timothy (ed.) and Condie, Kent C. (Series ed.), Elsevier, Amsterdam, pp. 675-726.

1158 Shervais, J.W., Jean, M.M., 2012. Inside the subduction factory: Modeling fluid mobile element 1159 enrichment in the mantle wedge above a subduction zone. Geochimica et Cosmochimica $1160 \quad$ Acta 95, 270-285.

1161 Shi, L., Francis, D., Ludden, J., Frederiksen, A., Bostock, M., 1998. Xenolith evidence for 1162 lithospheric melting above anomalously hot mantle under the northern Canadian Cordillera. 1163 Contributions to Mineralogy and Petrology 131, 39-53.

1164 Shirey, S.B., Richardson, S.H., 2011. Start of the Wilson Cycle at 3 Ga Shown by Diamonds 1165 from Subcontinental Mantle. Science 333, 434-436.

1166 Singer, B.S., Jicha, B.R., Leeman, W.P., Rogers, N.W., Thirlwall, M.F., Ryan, J., Nicolaysen, 1167 K.E., 2007. Along-strike trace element and isotopic variation in Aleutian Island arc basalt: 1168 Subduction melts sediments and dehydrates serpentine. Journal of Geophysical Research 1169 112, 1-26.

1170 Sluggett, C.L., 2008. Quaternary alkaline and calc-alkaline basalts in southern British Columbia: 1171 mixed signals from mantle sources above the southern edge of the Juan de Fuca-Pacific slab 1172 window. M.Sc. Thesis, Department of Earth Sciences, Simon Fraser University, British 1173 Columbia.

1174 Søager, N., Holm, P.M., Thirlwall, M.F., 2015. Sr, Nd, Pb and Hf isotopic constraints on mantle 1175 sources and crustal contaminants in the Payenia volcanic province, Argentina. Lithos 2121176 $215,368-378$.

1177 Souther, J.G., 1986. The western Anahim Belt: root zone of a peralkaline magma system. 1178 Canadian Journal of Earth Sciences 23, 895-908 
1179 Souther, J.G., 1991. Chapter 14 Volcanic regimes. In: Gabrielse, H., Yorath, C.J. (Eds.), 1180 Geology of the Cordilleran Orogen in Canada, Geology of Canada no. 4, Geological Survey 1181 of Canada. Ottawa, Canada, 457-490.

1182 Stolz, A. J., Jochum, K.P., Spettel, B., Hofmann, A.W., 1996. Fluid- and melt-related enrichment 1183 in the subarc mantle: Evidence from $\mathrm{Nb} / \mathrm{Ta}$ variations in island-arc basalts. Geology 24: $1184 \quad 587-590$.

1185 Stracke, A., Hofmann, A.W., Hart, S.R., 2005. FOZO, HIMU, and the rest of the mantle zoo. 1186 Geochemistry, Geophysics, Geosystems 6, 1-20.

1187 Struik, L.C., 1986. Imbricated terranes of the Cariboo gold belt with correlations and 1188 implications for tectonics in southeastern British Columbia. Canadian Journal of Earth 1189 Sciences 23, 1047-1061.

1190 Sun, M., Kerrich, R., 1995. Rare earth element and high field strength element characteristics of 1191 whole rocks and mineral separates of ultramafic nodules in Cenozoic volcanic vents of 1192 southeastern British Columbia, Canada. Geochimica et Cosmochimica Acta 59, 4863-4879.

1193 Sun, S.S., McDonough, W.F., 1989. Chemical and isotopic systematics of oceanic basalts: 1194 implications for mantle composition and processes. In: Saunders A.D., Norry, M. J. (Eds.), 1195 Magmatism in the Ocean Basins. Society of London, Special Publications 42, 313-345.

1196 Tang, Y-J., Zhang, H-F., Ying, J-F., Su, B-X., 2013. Widespread refertilization of cratonic and 1197 circum-cratonic lithospheric mantle. Earth-Science Reviews 118, 45-68.

1198 Taylor, S.R., McLennan, S.M., 1995. The Geochemical Evolution of the Continental Crust. $1199 \quad$ Reviews of Geophysics 32, 241-265.

1200 Thomas, M.D., 2009. Geological Significance of New Aeromagnetic Data from the Quesnel 1201 Survey Area (Portions of NTS 93G E Half and 93H W Half), Central British Columbia: A 

Ottawa, Ontario.

1204 Thorkelson, D.J., Madsen, J.K., Sluggett, C.L., 2011. Mantle flow through the Northern 1205 Cordilleran slab window revealed by volcanic geochemistry. Geology 39, 267-270.

1206 Thorkelson, D.J., Taylor, R.P., 1989. Cordilleran slab windows. Geology 17, 833-836.

1207 Todt, W., Cliff, R.A., Hanser, A., Hofmann, A.W., 1993. Re-calibration of NBS lead standards 1208 using 202Pb $+205 \mathrm{~Pb}$ double spike. Terra Abstract 5, 396 .

1209 Uysal, I., Ersoy, E.Y., Karslı, O., Dilek, Y., Sadıklar, M.B., Ottley, C.J., Tiepolo, M., Meisel, T., 1210 2012. Coexistence of abyssal and ultra-depleted SSZ type mantle peridotites in a NeoTethyan Ophiolite in SW Turkey: Constraints from mineral composition, whole-rock

Wang, W., Takahashi, E., Sueno, S., 1998. Geochemical properties of lithospheric mantle 1215 beneath the Sino-Korea craton; evidence from garnet xenocrysts and diamond inclusions. geochemistry (major-trace-REE-PGE), and Re-Os isotope systematics. Lithos 132-133, $50-69$. Physics of the Earth and Planetary Interiors 107, 249-260.

Wang, Q., Wyman, D., Zhao, Z-H., Xu, J-F., Bai, Z-H., Xiong, X-L., Dai, T.-M., Li, C-F., Chu, Z-Y., 2007. Petrogenesis of Carboniferous adakites and $\mathrm{Nb}$-enriched arc basalts in the Alataw area, northern Tianshan Range (western China): Implications for Phanerozoic crustal growth in the Central Asia orogenic belt. Chemical Geology 236, 42-64.

Wilshire, H.G., Meyer, C.E., Nakata, J.K., Calk, L.C., Shervais, J.W., Nielson, J.E., Schwarzman, E.C., 1988. Mafic and ultramafic xenoliths from volcanic rocks of the western United States. USGS Professional Paper 1443, Department of the Interior, Washington, DC, pp. 179. 
1225 Wilshire, H.G., Pike, J.E.N., Meyer, C.E., Schwarzman, E.C., 1980. Amphibole-rich veins in 1226 lherzolite xenoliths, Dish Hill and Deadman Lake, California. American Journal of Science, 1227 280-A, Part 2, 576-593.

1228 Winchester, J.A., Floyd, P.A., 1977. Geochemical discrimination of different magma series and 1229 their differentiation products using immobile elements. Chemical Geology 20, 325-343.

1230 Wu, F.-Y., Walker, R.J., Ren, X.-W., Sun, D.-Y., Zhou, X.-H., 2003. Osmium isotopic 1231 1232 1233 1234 1235 1236 1237 1238 constraints on the age of lithospheric mantle beneath northeastern China. Chemical Geology 196, 107-129.

Wu, F.-Y., Walker, R.J., Yang, Y.-H., Yuan, H.-L., Yang, J.-H., 2006. The chemical-temporal evolution of lithospheric mantle underlying the North China Craton. Geochimica et Cosmochimica Acta 70, 5013-5034.

Wyman, D., Kerrich, R., 2010. Mantle plume - volcanic arc interaction: consequences for magmatism, metallogeny, and cratonization in the Abitibi and Wawa subprovinces, Canada. Canadian Journal of Earth Sciences 47, 565-589.

Xu, X., O’Reilly, S.Y., Griffin, W.L., Zhou, X., 2003. Enrichment of upper mantle peridotite: petrological, trace element and isotopic evidence in xenoliths from SE China. Chemical Geology 198, 163-188.

Yanagi, T., 2011. Chemical Composition of Continental Crust and the Primitive Mantle. Chapter 2 In Arc Volcano of Japan: Generation of Continental Crust from the Mantle. Berlin, New York, Springer Science and Business Media, pp. 9-17.

Yaxley, G.M., Green, D.H. and Kamenetsky, V., 1998. Carbonatite Metasomatism in the 1246 Southeastern Australian Lithosphere. Journal of Petrology 39, 1917-1930. 
1247 Zack, T., John, T., 2007. An evaluation of reactive fluid flow and trace element mobility in $1248 \quad$ subducting slabs. Chemical Geology 239, 199-216.

1249 Zhang, M., Stephenson, P.J., O'Reilly, S.Y., McCulloch, M.T., Norman, M., 2001. Petrogenesis

1250 and Geodynamic Implications of Late Cenozoic Basalts in North 1251 Queensland, Australia: Trace-element and $\mathrm{Sr}-\mathrm{Nd}-\mathrm{Pb}$ Isotope Evidence. Journal of Petrology $1252 \quad 42,685-719$.

1253 Zheng, J.P., Griffin, W.L., O'Reilly, S.Y., Yu, C.M., Zhang, H.F., Pearson, N., Zhang, M., 2007. 1254 Mechanism and timing of lithospheric modification and replacement beneath the eastern 1255 North China Craton: Peridotitic xenoliths from the 100 Ma Fuxin basalts and a regional 1256 synthesis. Geochimica et Cosmochimica Acta 71, 5203-5225.

1257

1258

1259

\section{Figure Captions}

1260 Fig. 1. Location of the Tasse alkaline basalts (TAB), current tectonic features, and Late Cenozoic 1261 volcanic belts (shown schematically) of the Canadian Cordillera and adjacent United States. 1262 GVB: Garibaldi volcanic belt; CG: Chilcotin Group. Modified from Bevier et al. (1979), 1263 Edwards and Russell (2000) and Thorkelson et al. (2011).

Fig. 2. Geological map of associated terranes (Slide Mountain, Quesnel and Kootenay) of the 1266 Tasse sampling areas within Southeastern British Columbia. Sampling region is denoted by the 1267 red circle (modified from Ferri and Schiarizza, 2006). 
1269 Fig. 3. Google Earth overlay of magnetic anomalies for the Tasse and Wasko properties of 1270 Barker Minerals Ltd. Numbers associated with the Tasse magnetic anomalies are assigned to 1271 sampling locations. Magnetic highs are seen as purple and red (modified from Barker Minerals 1272 Ltd.).

1273

1274 Fig. 4. Representative samples of spinel lherzolites found in the Tasse region of British 1275 Columbia. (a-c) Spinel lherzolite xenoliths set in host alkaline basalts. (d) Oxidized spinel 1276 lherzolite sample. (e-f) Spinel lherzolite samples displaying pyroxene-spinel rich bands and 1277 lherzolite-pyroxenite layers, respectively.

1278 Fig. 5. Plane (a, c, e) and cross-polarized (b, d, f) photomicrographs of spinel lherzolites. (a-d)

1279 Representative igneous textures and mineral associations. (e-f) Resorption texture of 1280 clinopyroxene and associated spinel (Ol: olivine; Opx: orthopyroxene; Cpx: clinopyroxene; Spl: 1281 spinel).

1282

1283 Fig. 6. SEM back-scattered electron (BSE) images of spinel lherzolites. (a-b) Spinel (white) 1284 associated with resorbed clinopyroxene (light grey) and olivine (dark grey). (c-d) Common 1285 textural features of pyroxenes and olivine (light grey and dark grey) with associated spinel (Ol: 1286 olivine; Opx: orthopyroxene; Cpx: clinopyroxene; Spl: spinel).

1288 Fig. 7. Plane and cross polarized photomicrographs of alkaline basalts (a-b) Representative fine1289 grained textures and mantle xenocrysts. (c-d) Quartz xenocryst with reaction rim of unknown 1290 fine-grained minerals and skeletal textures, respectively. (Mineral abbreviations: Ol - olivine; 1291 Qtz - quartz) 
1293 Fig. 8. Ratios (a) Nb/Ta, (b) Zr/Hf and (c) Y/Ho of Tasse mantle xenoliths and alkaline basalts. 1294 Shaded regions represent spinel peridotites, MORB, OIB and PM are from Jochum et al. (1989). 1295 Chondritic values are represented as the black line crossing primitive mantle (PM) shown as a 1296 black star.

Fig. 9. Chondrite- (a-d) and N-MORB- (e-h) normalized patterns for (a and e) Group 1 1299 lherzolites, (b and f) Group 2 lherzolites, (c and g) Group 3 lherzolites and (d and h) Outlier 1300 xenolith samples. Chondrite and N-MORB normalization values are McDonough and Sun (1995) 1301 and Sun and McDonough (1989), respectively.

1303 Fig. 10. La/ $\mathrm{Yb}_{\mathrm{cn}}$ vs. (a) $\mathrm{Ti} / \mathrm{Ti}^{*}{ }_{\mathrm{MORB}}$ and (b) $\mathrm{Zr} / \mathrm{Zr}^{*}{ }_{\mathrm{MORB}}$ plots. Chondrite and N-MORB 1304 normalization values are McDonough and Sun (1995) and Sun and McDonough (1989), 1305 respectively.

1307 Fig. 11. (a) Chondrite-normalized patterns and (b) N-MORB-normalized patterns of the Tasse 1308 alkaline basalts. Chondrite and N-MORB normalization values are McDonough and Sun (1995) 1309 and Sun and McDonough (1989), respectively.

1311 Fig. 12. $\mathrm{Sr}-\mathrm{Nd}-\mathrm{Pb}$ isotopic plots of the Tasse alkaline basalts and volcanic rocks from a range of 1312 locations and tectonic settings. The shaded regions indicate isotopic source characteristics of 1313 mid-ocean ridge basalts (MORB), ocean island basalts (OIB), focal zone (FOZO), high- $\mu$ 1314 (HIMU) and continental crust from Stracke et al. (2005). Data was collected from Fretzdorff et 
1315 al., 2002 (Scotia Ridge); Holm et al., 2014 (Andean Southern Volcanic Zone); Kheirkhah et al., 13162015 (Turkish-Iranian Plateau); Kuritani et al., 2008 (Kurile Arc); Pearce et al., 1992 (Izo-Bonin

1317 Forearc); Peng et al., 2014 (Deccan Trap); Singer et al., 2007 (Aleutian Arc); Søager et al., 2015

1318 (Payenia Volcanic Province); Zhang et al., 2001 (North Queensland). Outlier samples were 1319 removed from the shaded regions and Deccan Traps.

1321 Fig. 13. Primitive mantle evolution plot (Mg/Si vs. Al/Si). Linear relationship indicates that the 1322 mantle xenoliths originated from a primitive upper mantle source (PUM). Major element oxide 1323 weight percent values are converted to ppm (modified from Canil and Lee, 2009).

1325 Fig. 14. Partial melting diagram utilizing $\mathrm{Mg \#}$ vs. $\mathrm{CaO}$ (wt.\%). Vertical lines at the top indicate 1326 the percent of partial melting from a primitive source. The grey shaded region represents 1327 Torishima and Conical Seamount harzburgite data. The purple shaded region represents 1328 Torishima and Conical Seamount dunite data. Data for the shaded regions were taken from Ishii 1329 et al. (1992).

1331 Fig. 15. Metasomatism discrimination plot between silicate and carbonatite melt metasomatism. 1332 The shaded region indicates Grand Comore xenoliths (from Coltorti et al., 1999) which have 1333 undergone carbonatite melt metasomatism. British Columbia lherzolite data was collected from 1334 Peslier et al. (2002). 


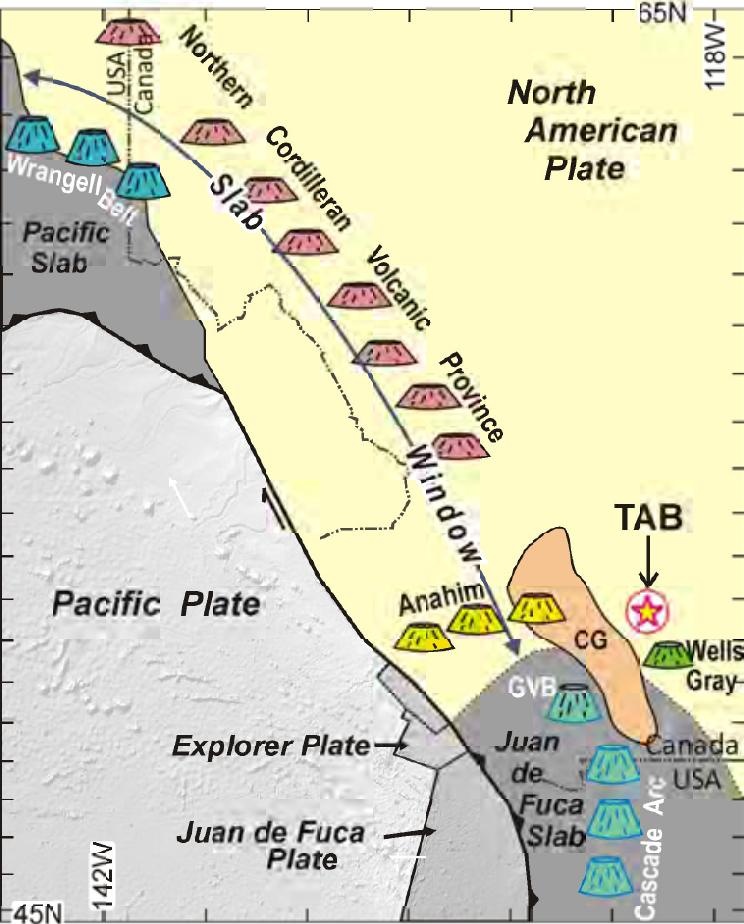









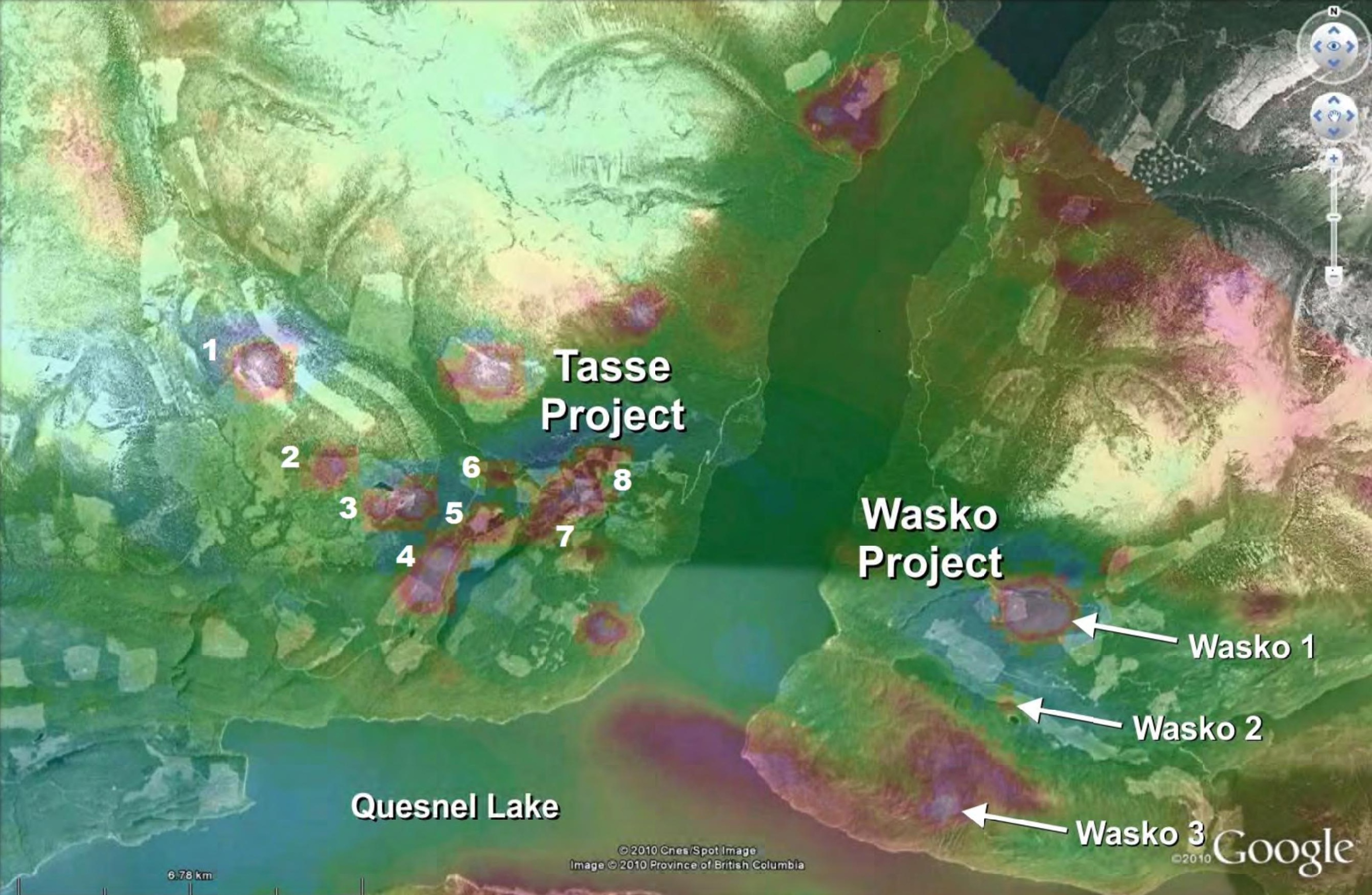




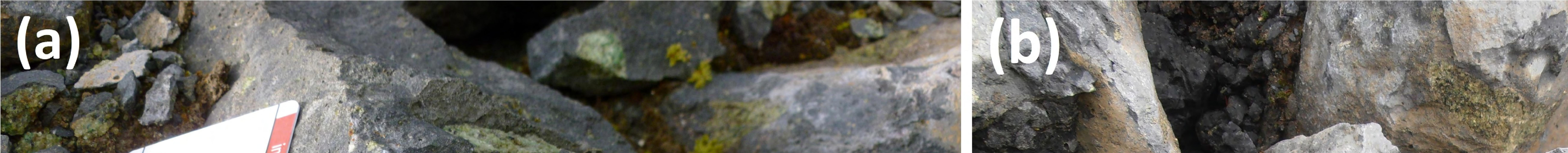
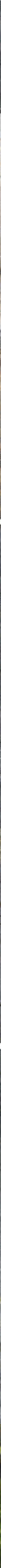

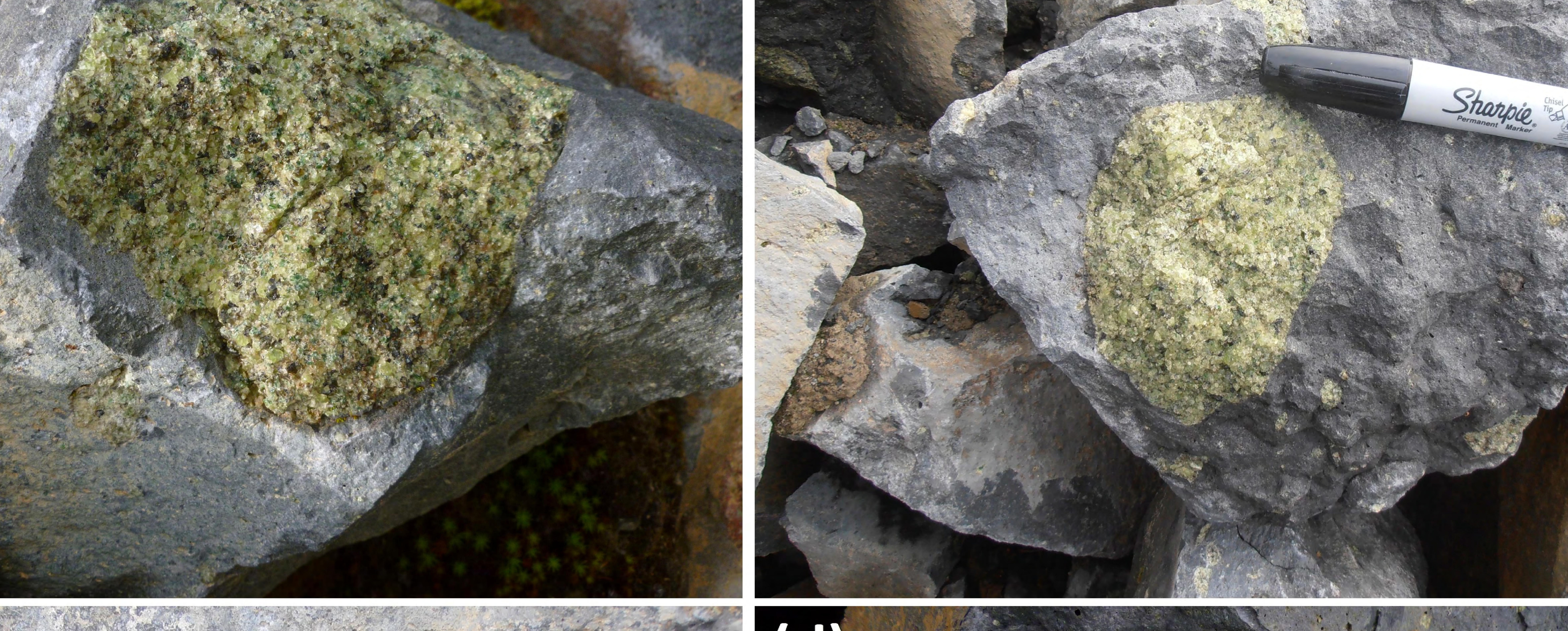

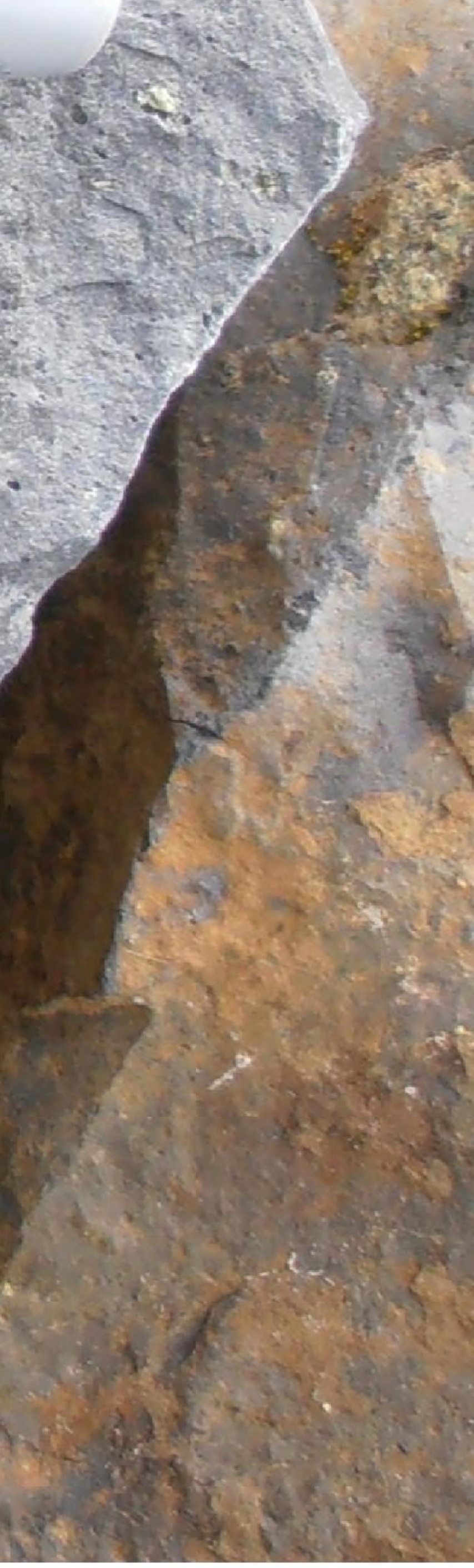

(c) $2 x^{2}=2 x=2$ (s)

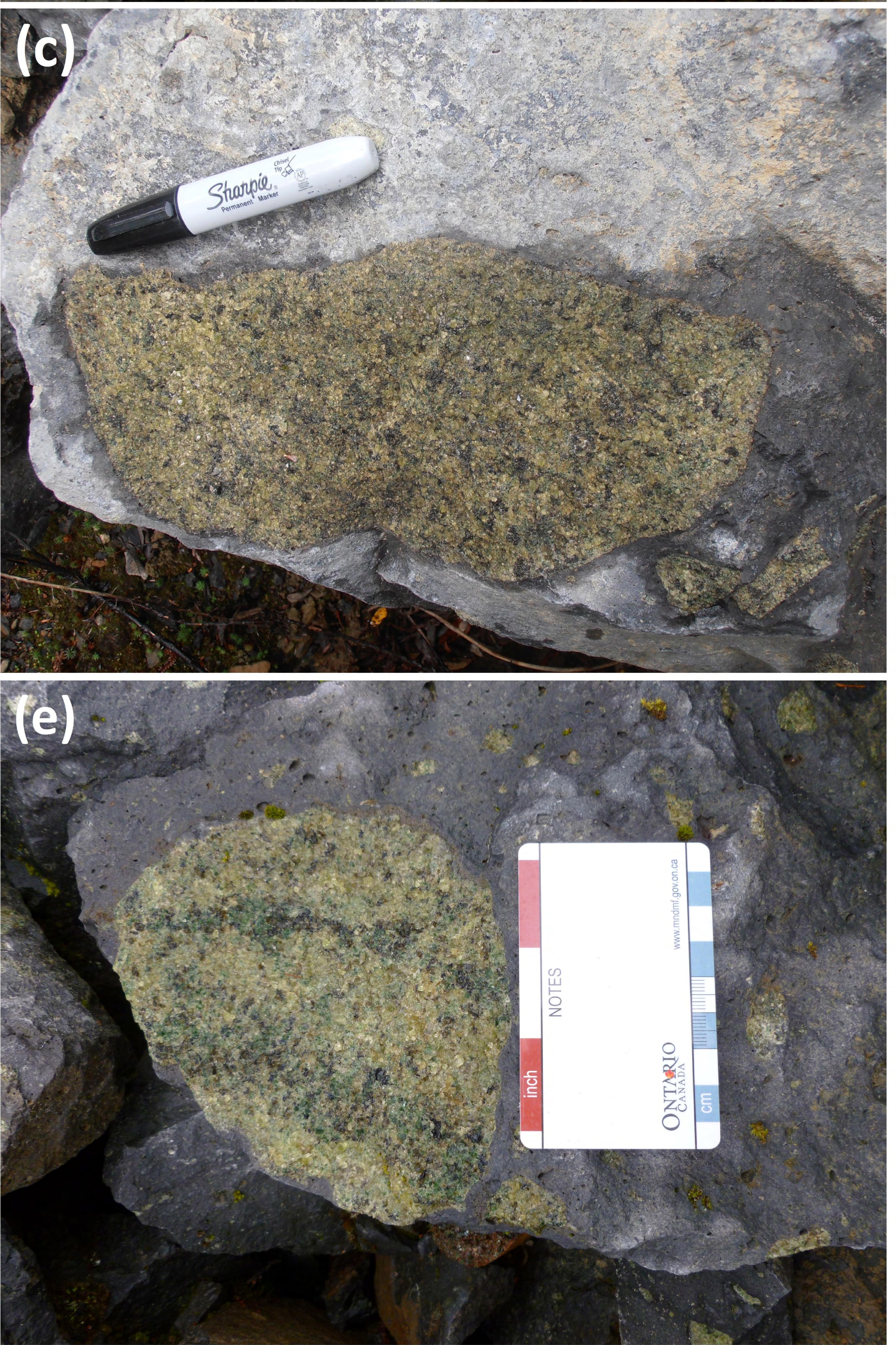

(e)

$-24)$

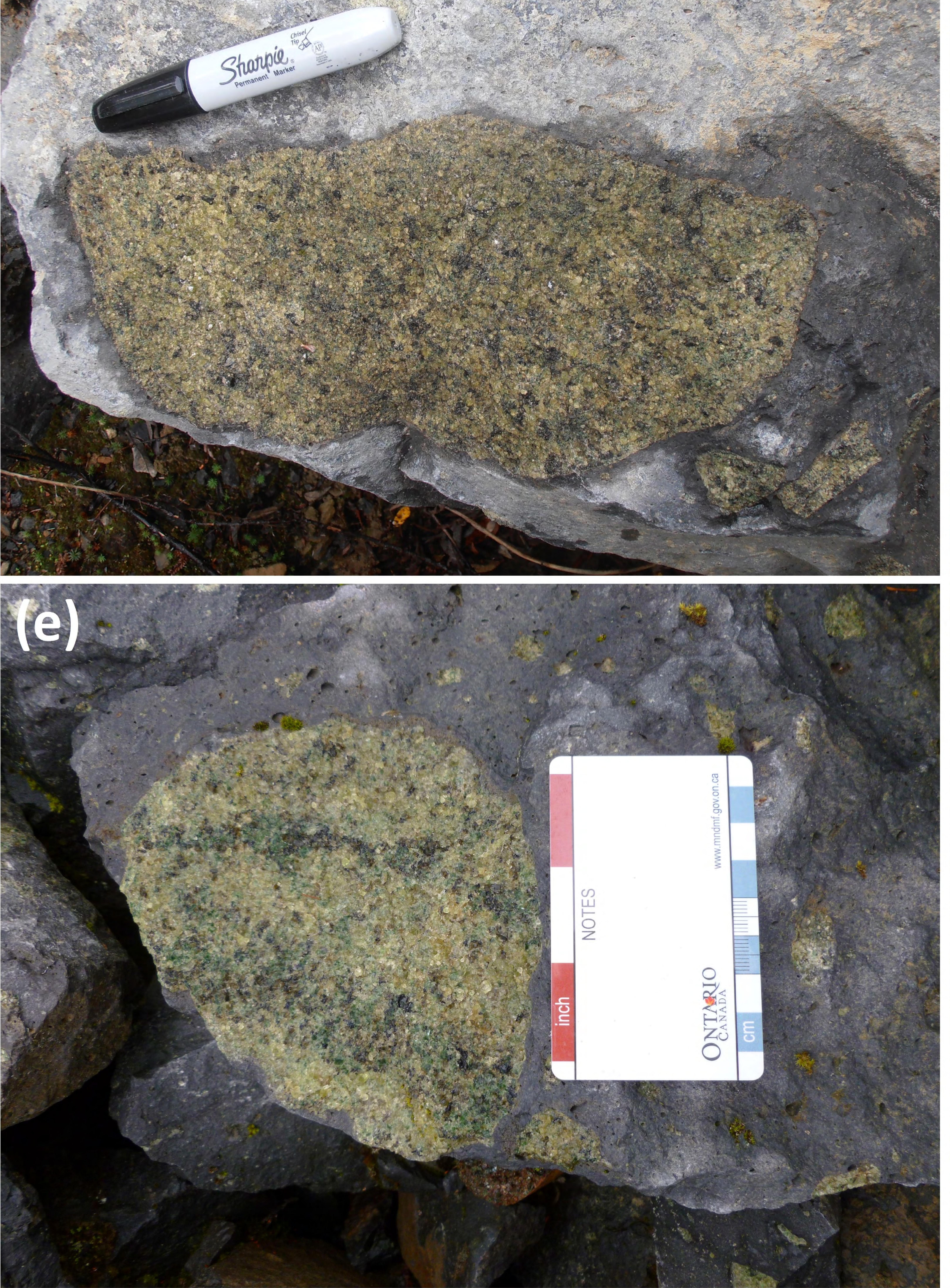

462,3

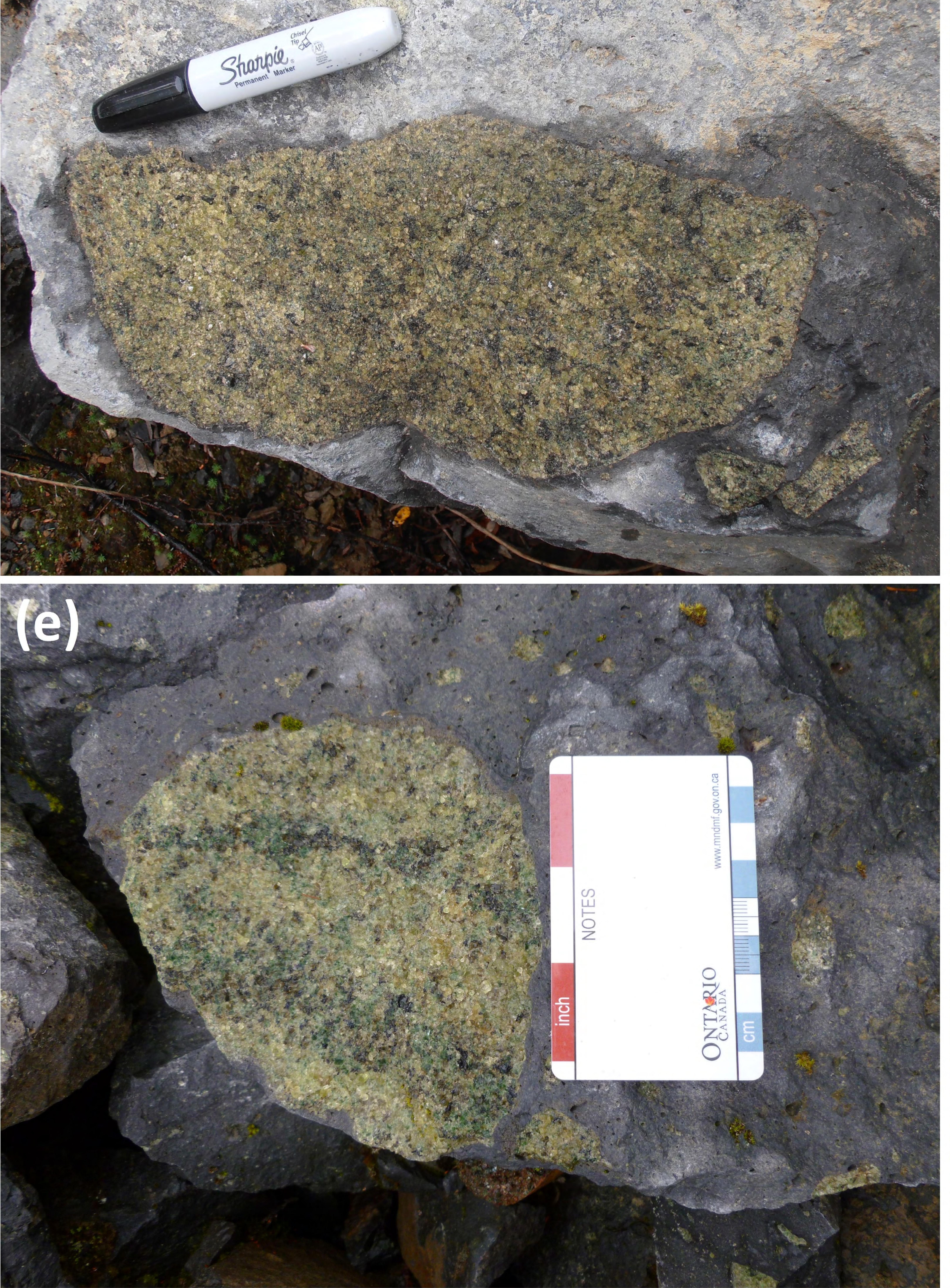

(f)

(d)
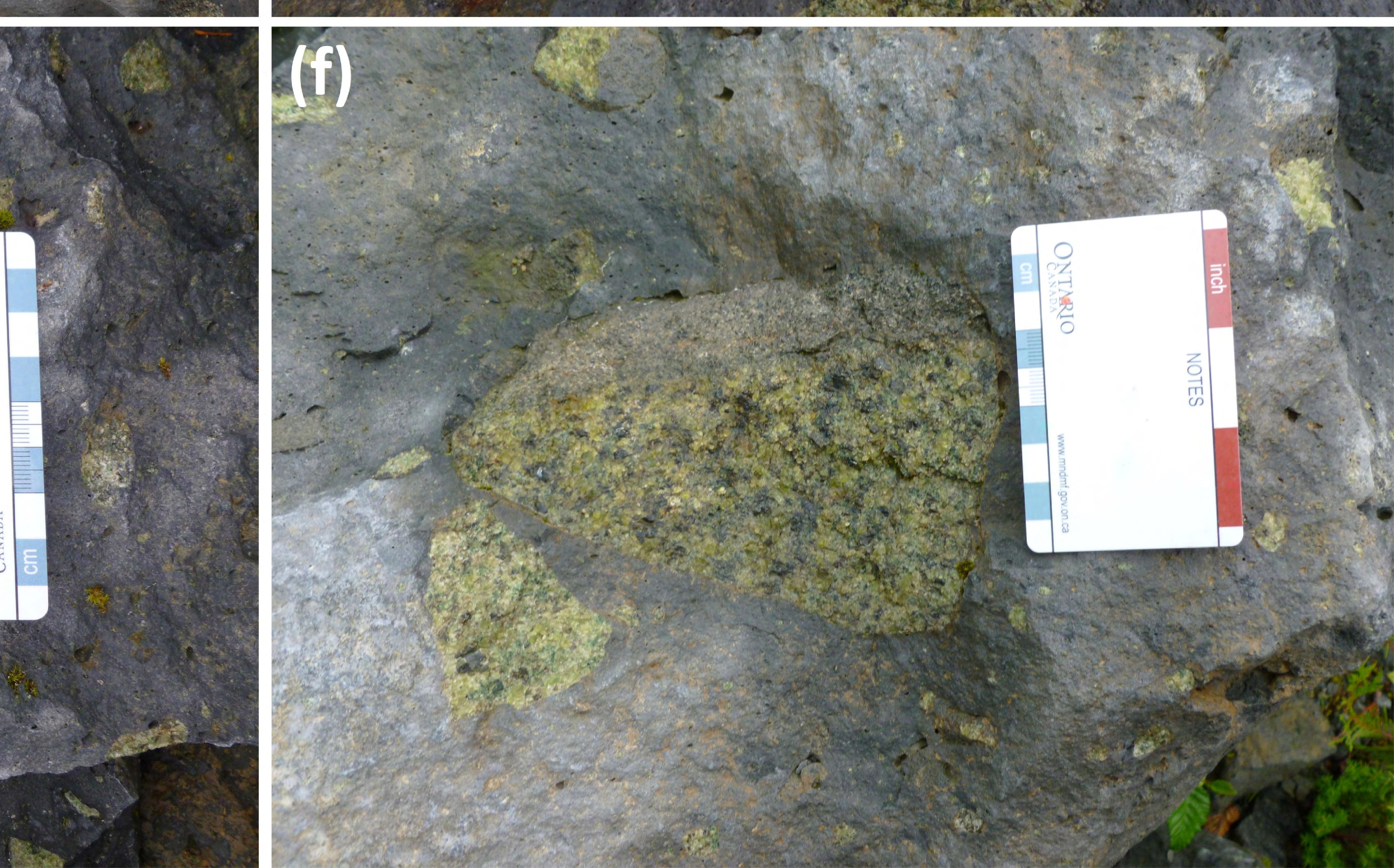

(V)

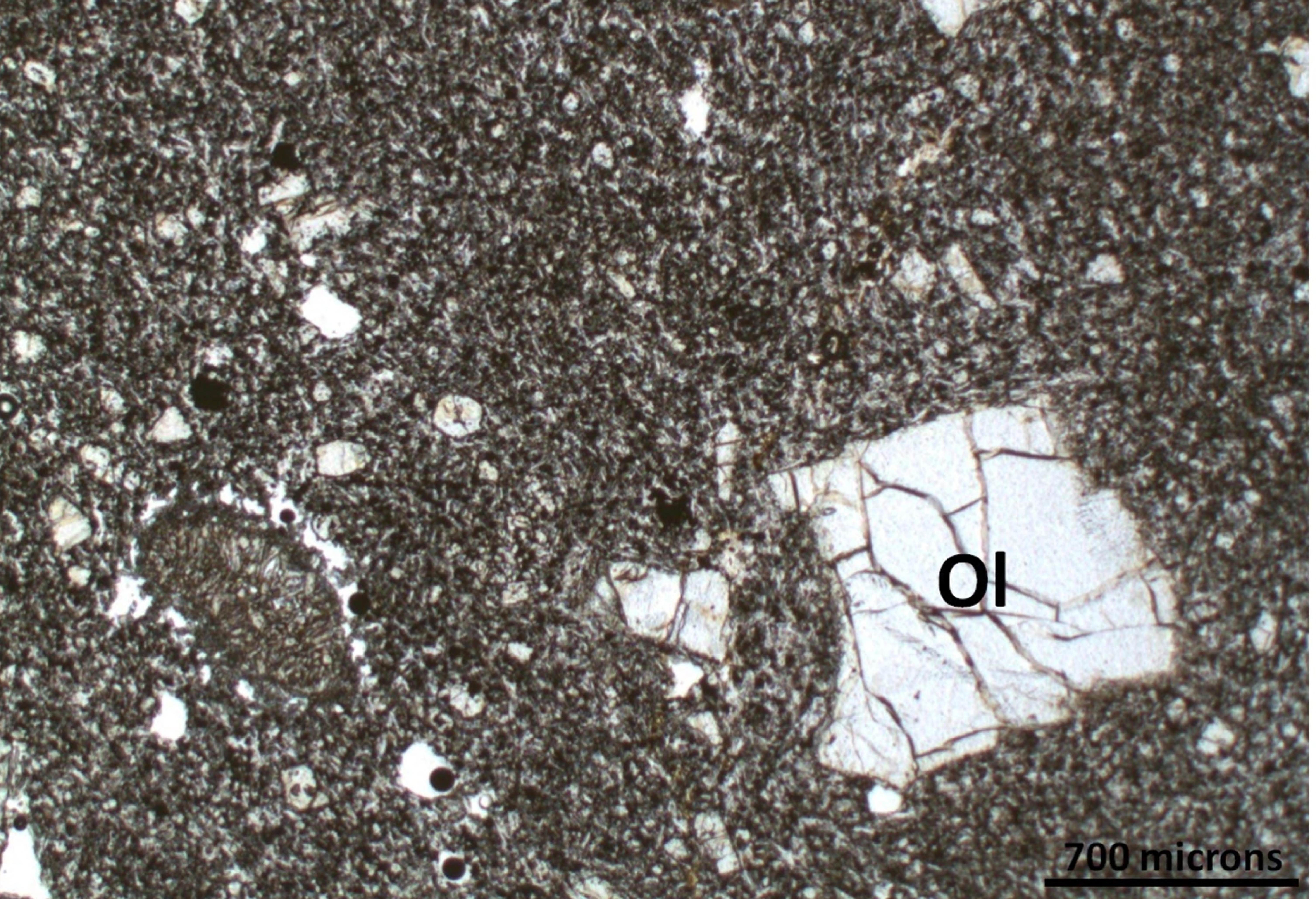

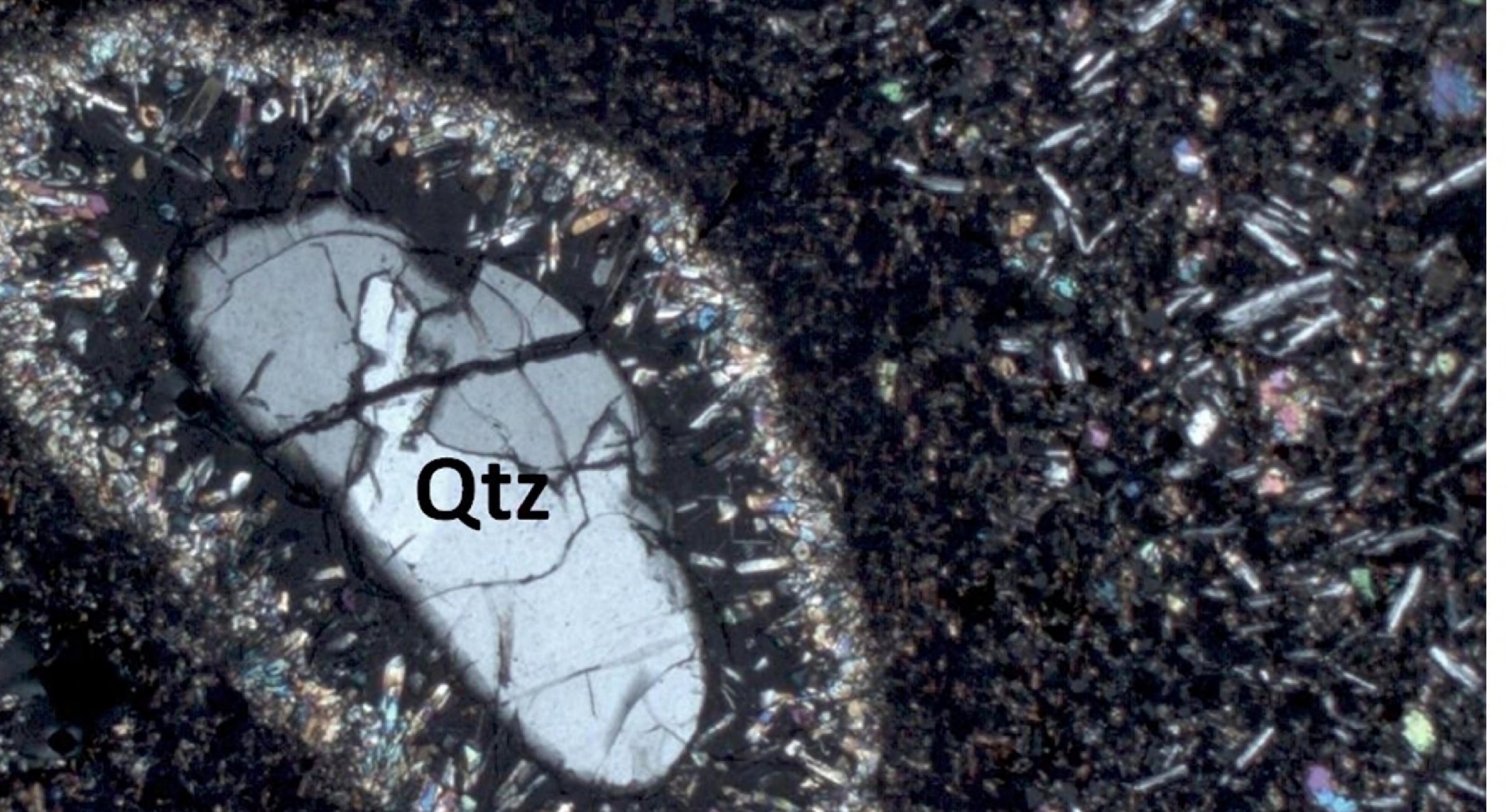

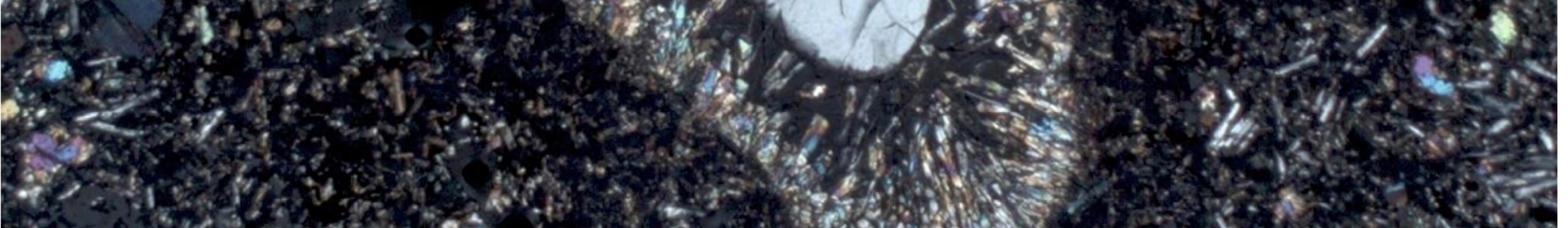

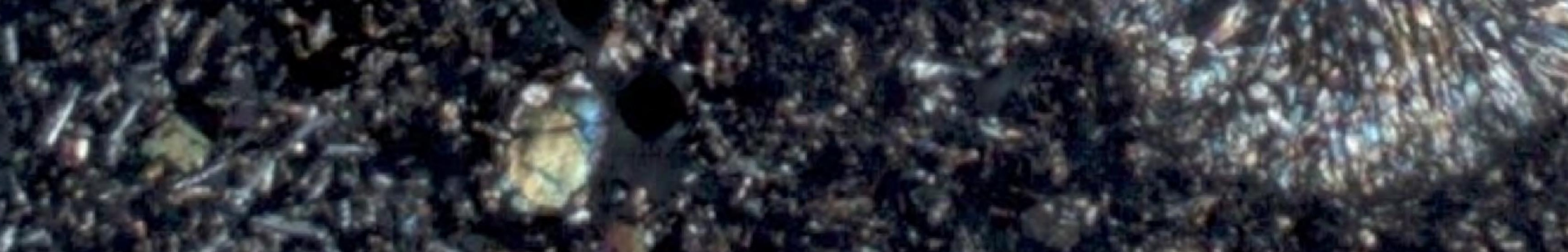

(D) 2 is

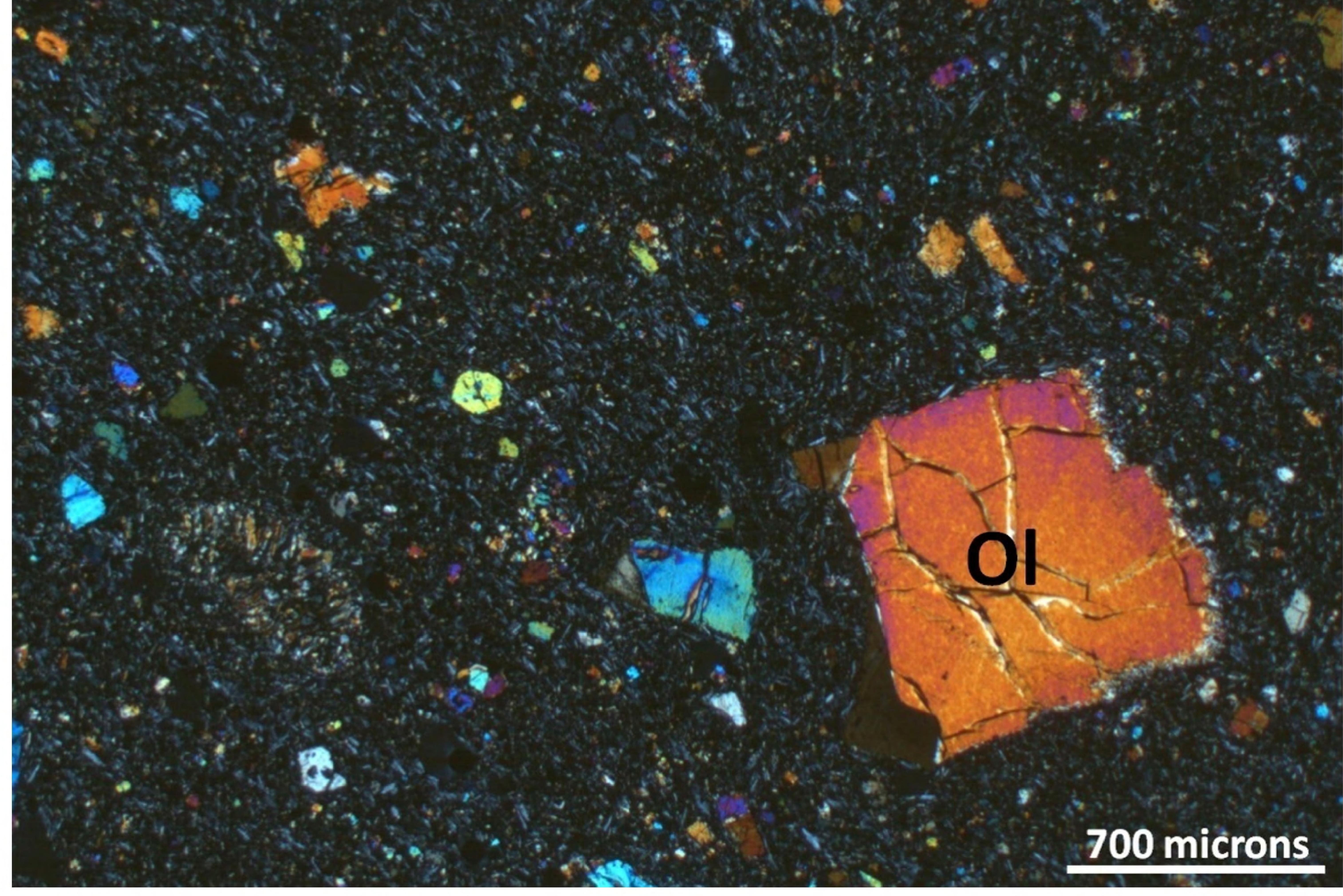

(d) $x^{2}$

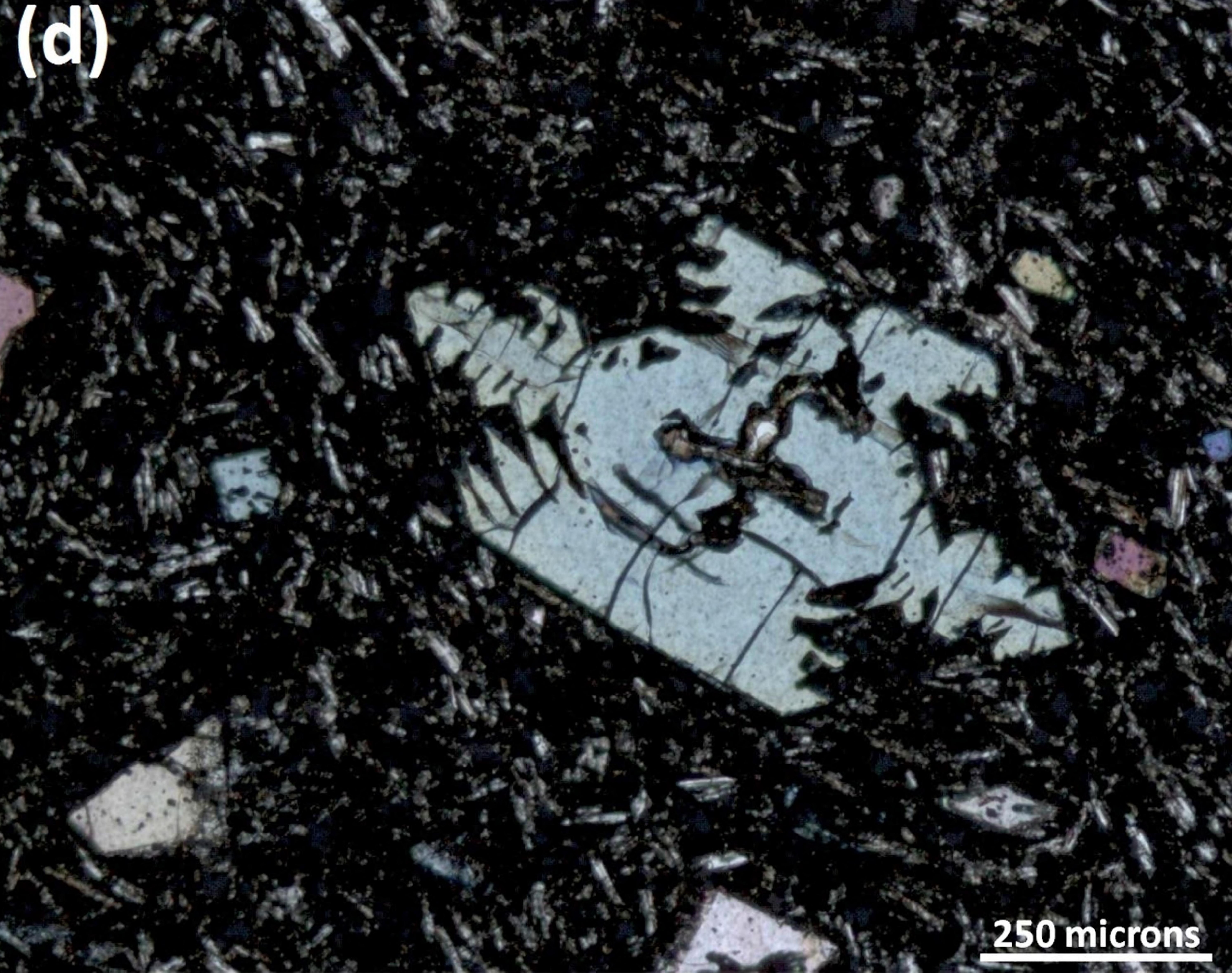



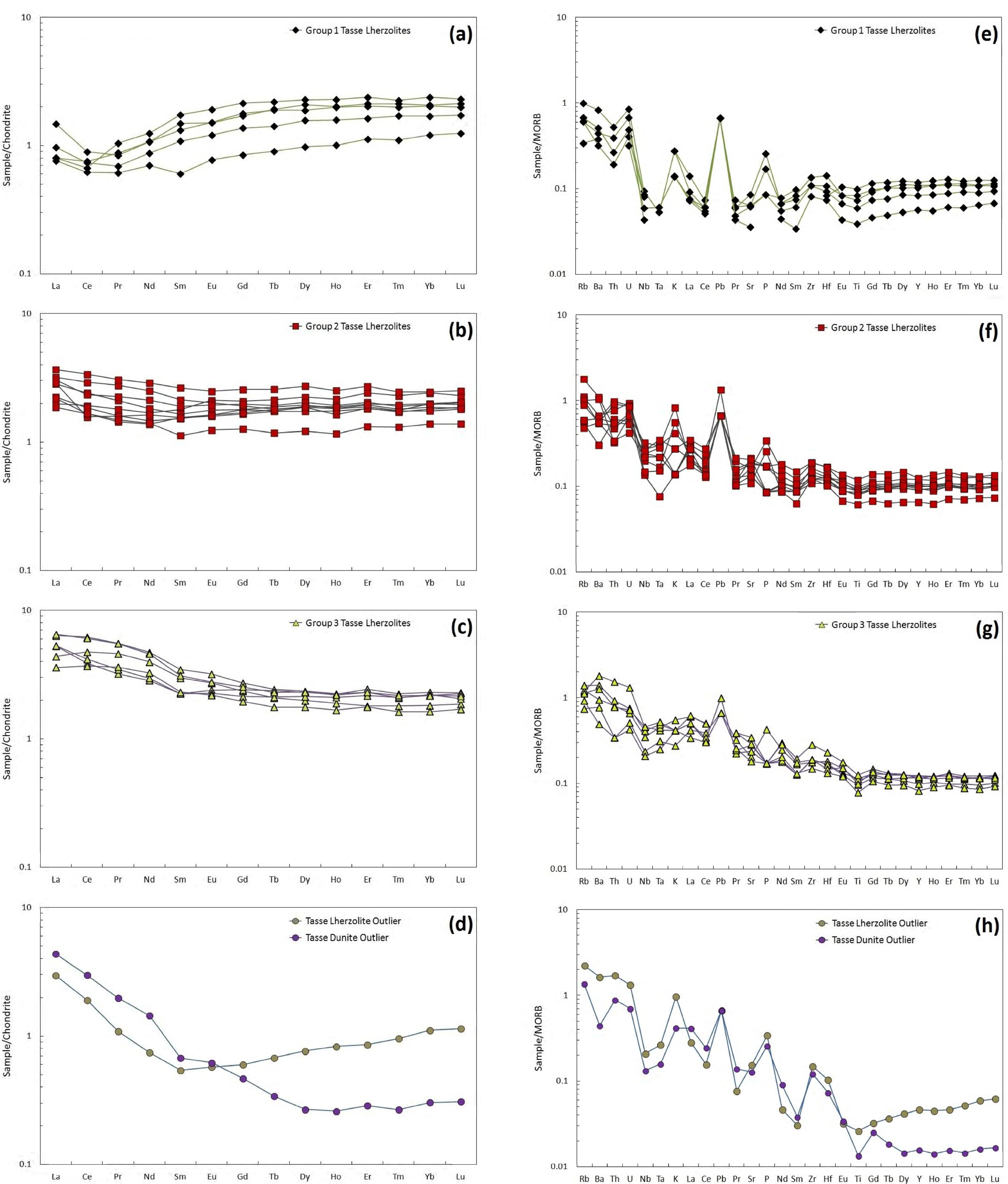


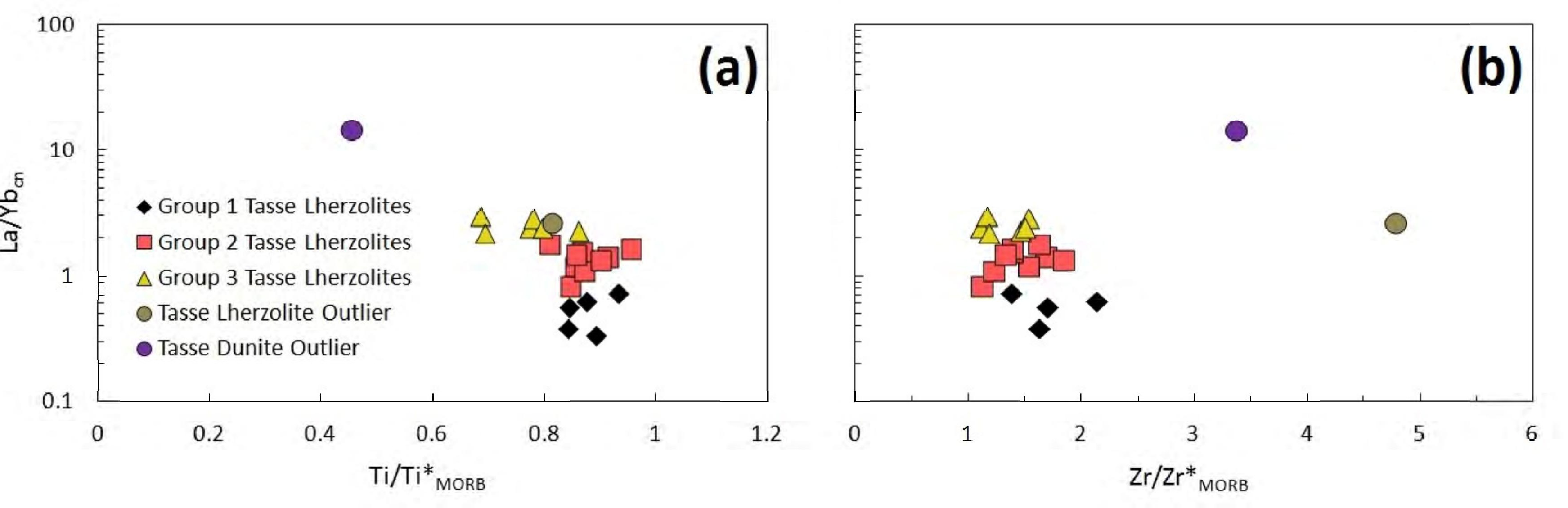



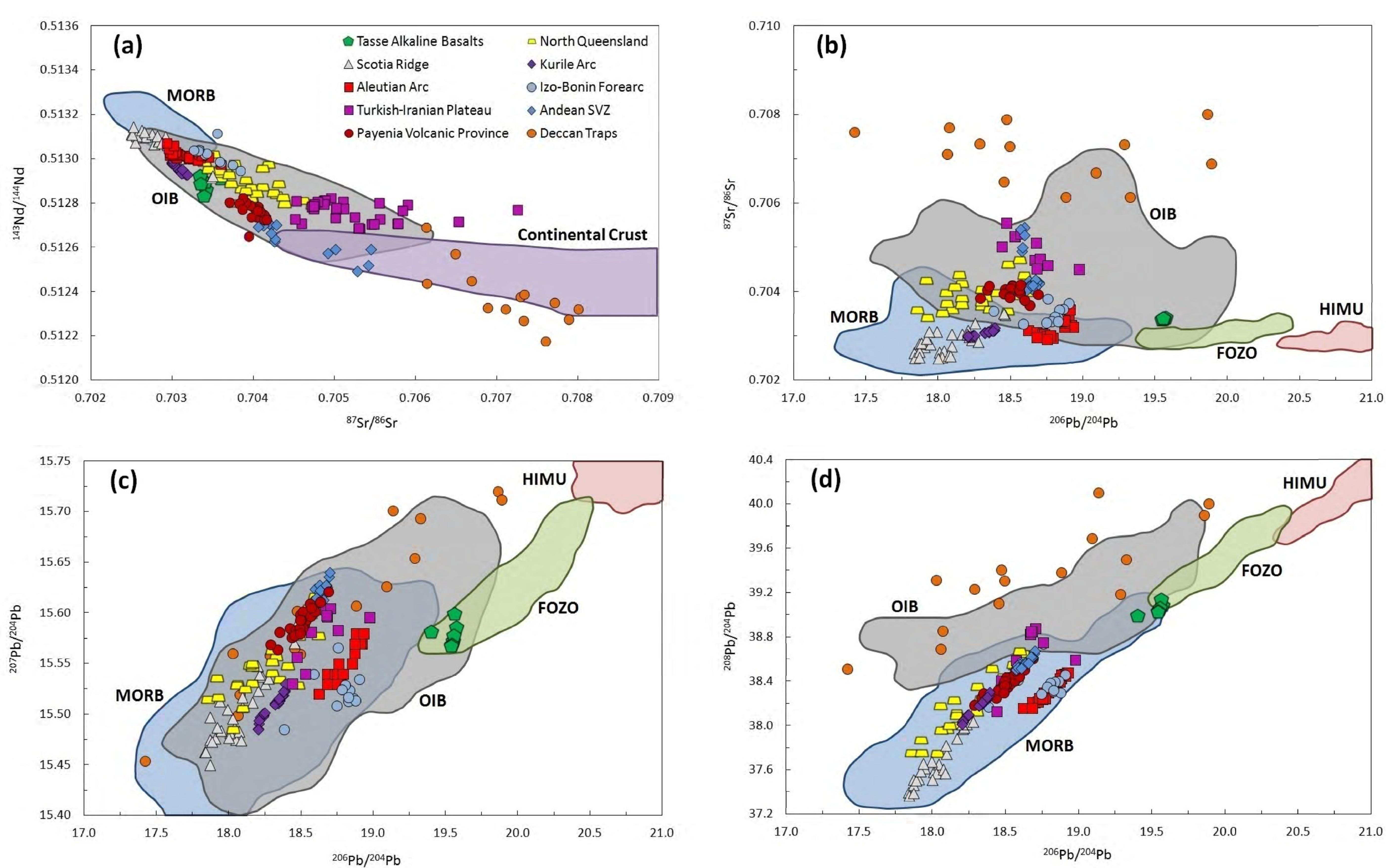


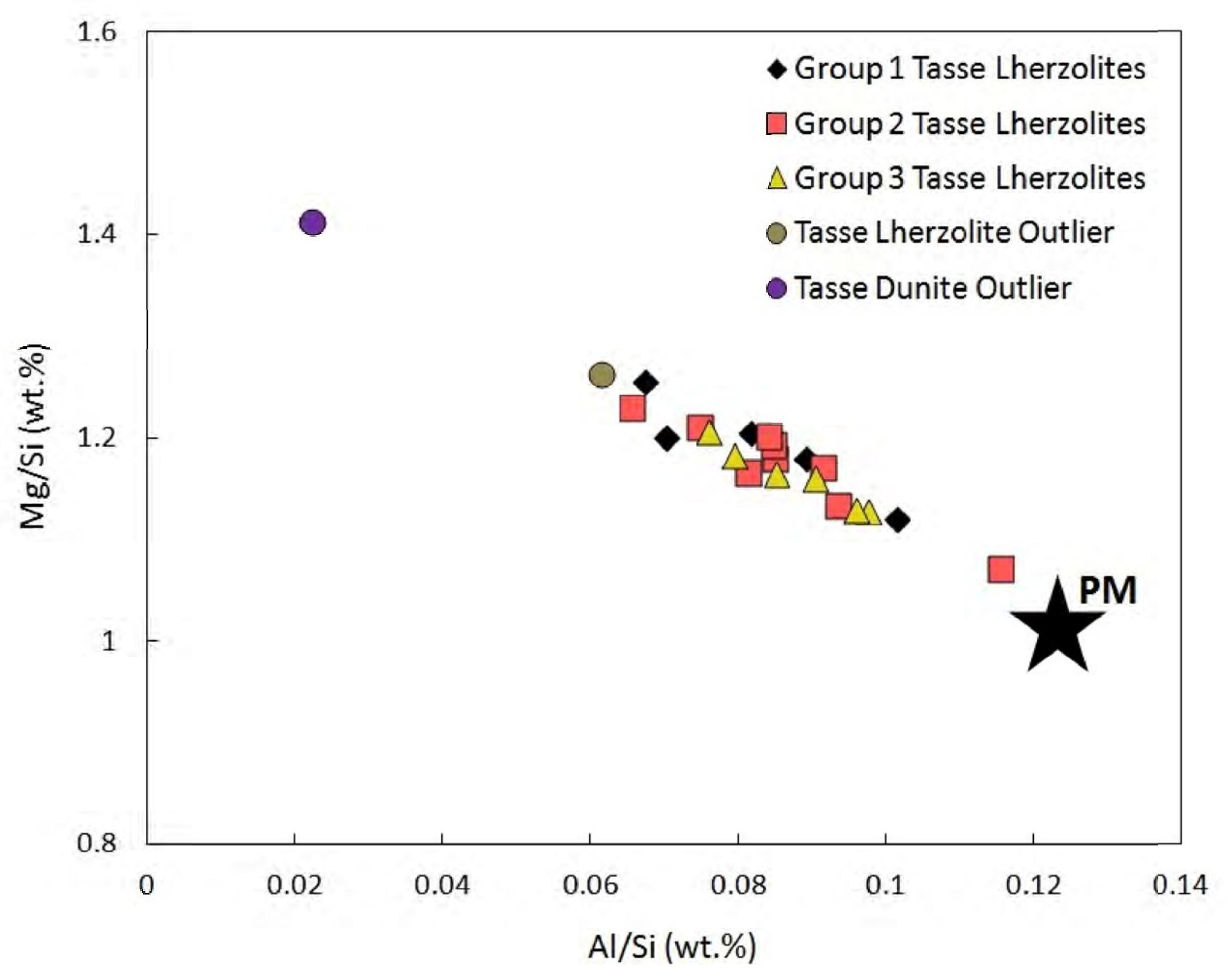




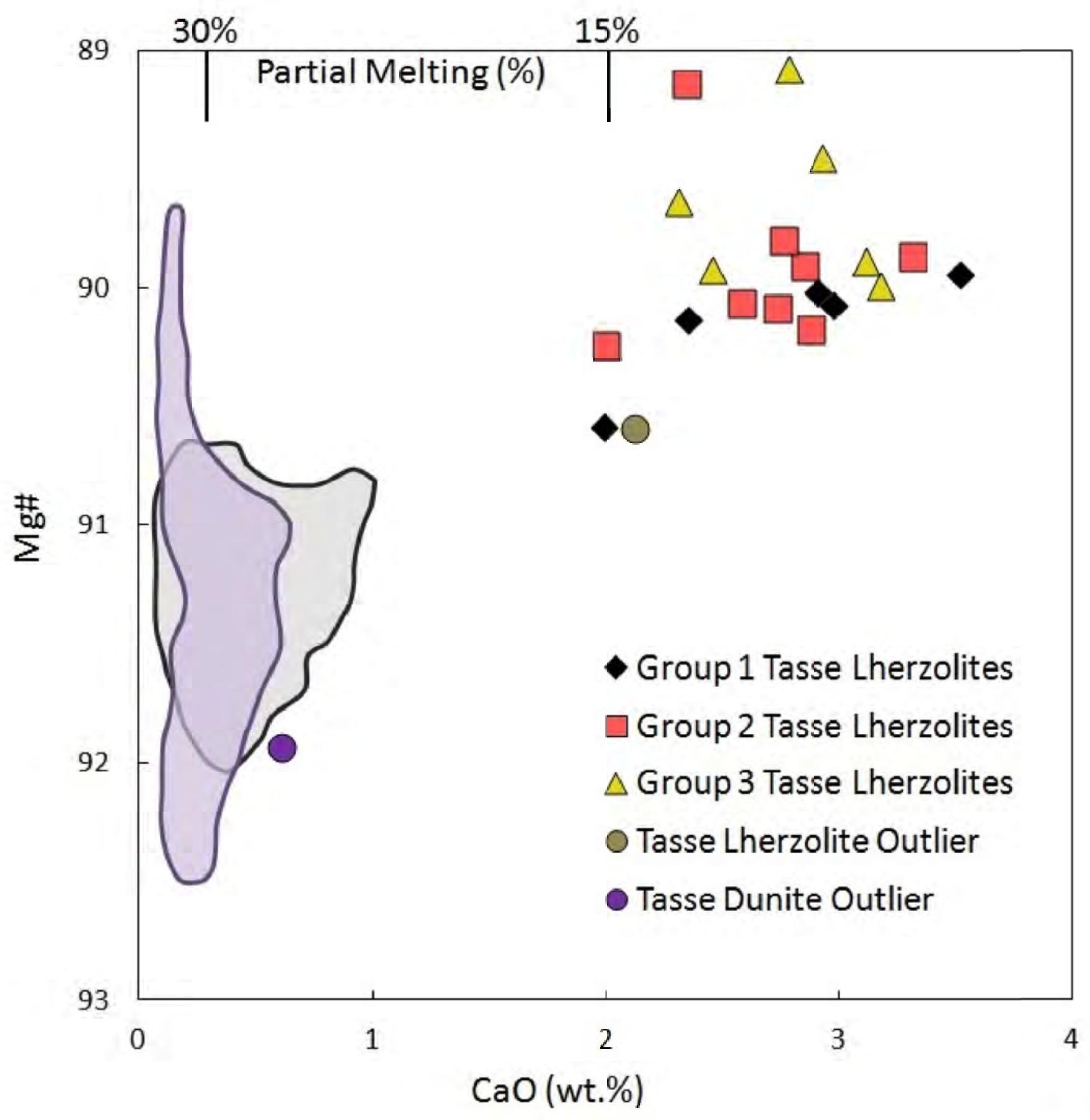




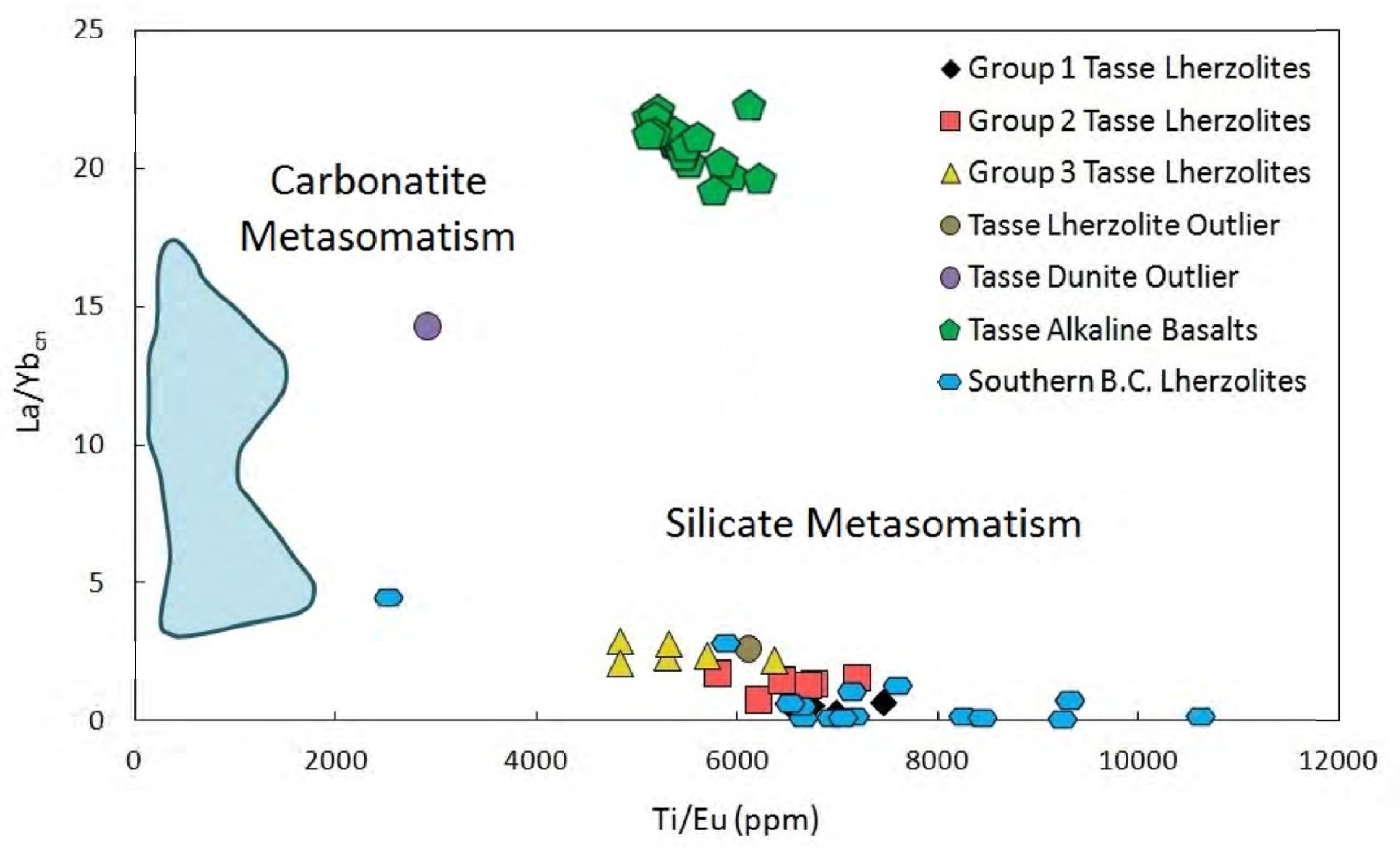


Table 1. Whole-rock major (wt.\%) and trace (ppm) element concentrations and significant element ratios for mantle xenoliths.

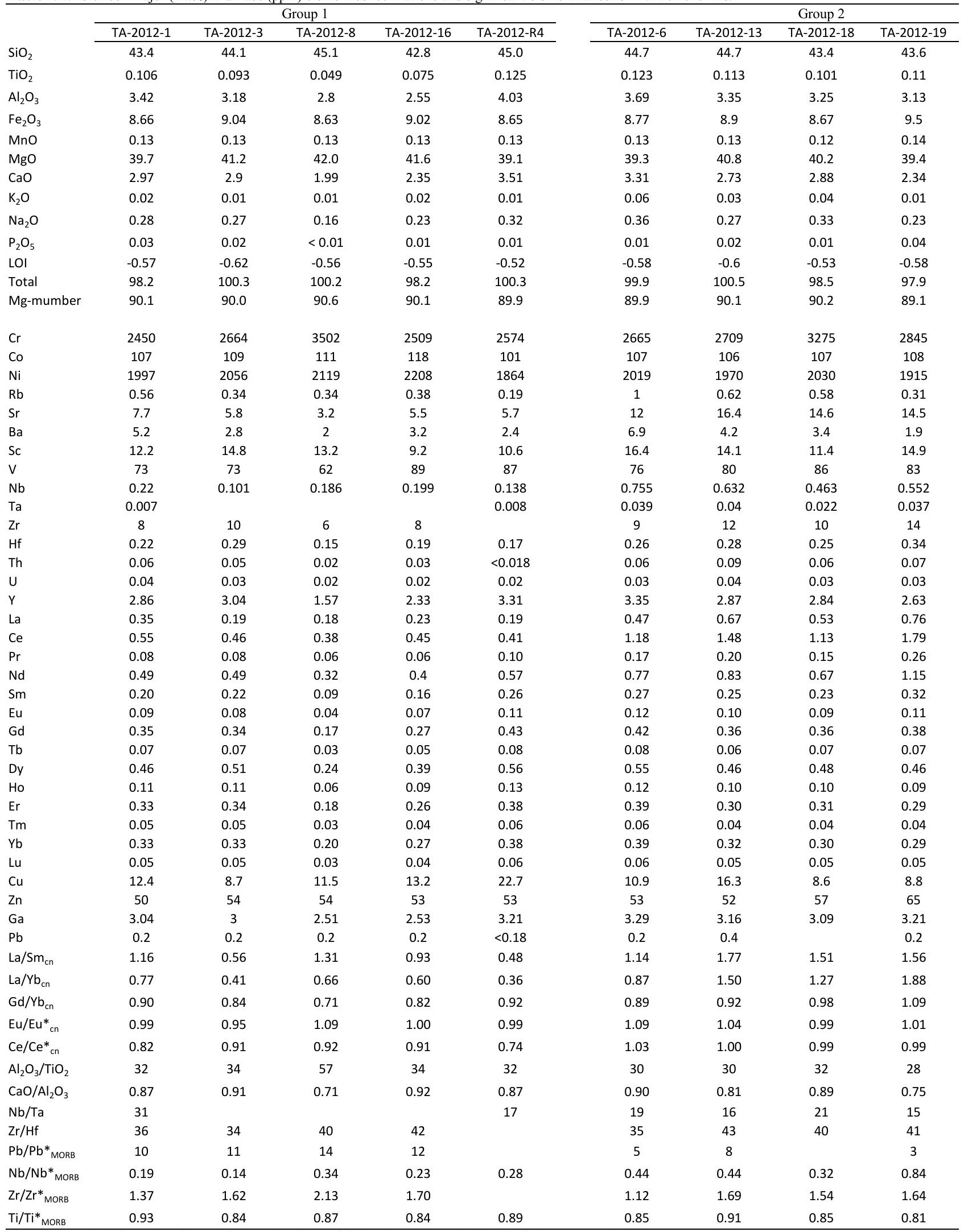

MORB: Normal Mid-Ocean Ridge Basalt; $\mathrm{cn}$ : Chondrite. $\mathrm{Pb} / \mathrm{Pb} *$ values were calculated relative to $\mathrm{Ce}$ and $\mathrm{Pr}$.

$\mathrm{Nb} / \mathrm{Nb}^{*}$ values were calculated relative to $\mathrm{U}$ and $\mathrm{K}$. $\mathrm{Zr} / \mathrm{Zr} *$ values were calculated relative to $\mathrm{Sm}$ and $\mathrm{Eu}$.

$\mathrm{Ti} / \mathrm{Ti}^{*}$ values were calculated relative to Eu and $\mathrm{Gd}$. 
Table 1. Continued

\begin{tabular}{|c|c|c|c|c|c|c|c|c|c|}
\hline & & & Group 2 & & & & Group 3 & & \\
\hline & TA-2012-45 & TA-2012-46 & TA-2012-49 & TA-2012-56 & TA-2012-62 & TA-2012-2 & TA-2012-10 & TA-2012-15 & TA-2012-44 \\
\hline $\mathrm{SiO}_{2}$ & 44.7 & 43.7 & 43.7 & 45.2 & 43.5 & 44.5 & 44.6 & 44.3 & 45.1 \\
\hline $\mathrm{TiO}_{2}$ & 0.117 & 0.107 & 0.1 & 0.15 & 0.078 & 0.135 & 0.143 & 0.159 & 0.121 \\
\hline $\mathrm{Al}_{2} \mathrm{O}_{3}$ & 3.61 & 2.89 & 3.25 & 4.61 & 2.52 & 3.11 & 3.84 & 3.33 & 3.82 \\
\hline $\mathrm{Fe}_{2} \mathrm{O}_{3}$ & 9.01 & 8.96 & 9.17 & 9.36 & 8.86 & 9.05 & 8.69 & 9.72 & 8.69 \\
\hline $\mathrm{MnO}$ & 0.13 & 0.13 & 0.13 & 0.14 & 0.13 & 0.13 & 0.13 & 0.14 & 0.13 \\
\hline $\mathrm{MgO}$ & 40.5 & 41.0 & 40.8 & 37.5 & 41.4 & 40.8 & 39.0 & 40.0 & 39.5 \\
\hline $\mathrm{CaO}$ & 2.85 & 2.58 & 2.76 & 3.77 & 2 & 2.45 & 3.11 & 2.78 & 3.17 \\
\hline $\mathrm{K}_{2} \mathrm{O}$ & 0.01 & 0.01 & 0.02 & 0.02 & 0.01 & 0.02 & 0.03 & 0.04 & 0.03 \\
\hline $\mathrm{Na}_{2} \mathrm{O}$ & 0.27 & 0.25 & 0.29 & 0.39 & 0.2 & 0.27 & 0.32 & 0.34 & 0.35 \\
\hline $\mathrm{P}_{2} \mathrm{O}_{5}$ & 0.02 & 0.01 & 0.03 & 0.02 & 0.01 & 0.05 & 0.02 & 0.02 & 0.02 \\
\hline LOI & -0.61 & -0.61 & -0.58 & -0.57 & -0.6 & -0.59 & -0.55 & -0.59 & -0.55 \\
\hline Total & 100.6 & 99.1 & 99.7 & 100.6 & 98.1 & 99.9 & 99.3 & 100.3 & 100.3 \\
\hline Mg-mumber & 89.9 & 90.1 & 89.8 & 88.8 & 90.2 & 89.9 & 89.9 & 89.1 & 90.0 \\
\hline $\mathrm{Cr}$ & 2615 & 2593 & 2312 & 2936 & 2347 & 2239 & 2981 & 2486 & 2647 \\
\hline Co & 106 & 106 & 104 & 98 & 110 & 107 & 105 & 110 & 101 \\
\hline $\mathrm{Ni}$ & 1962 & 1953 & 1901 & 1814 & 2054 & 2002 & 1881 & 2027 & 1875 \\
\hline $\mathrm{Rb}$ & 0.33 & 0.56 & 0.33 & 0.5 & 0.27 & 0.42 & 0.66 & 0.69 & 0.78 \\
\hline $\mathrm{Sr}$ & 17 & 19.1 & 9.8 & 18.5 & 11.9 & 18.3 & 21.3 & 31.1 & 25.2 \\
\hline $\mathrm{Ba}$ & 3.9 & 6.5 & 3.9 & 3.5 & 3.5 & 4.9 & 11.4 & 6 & 8.8 \\
\hline Sc & 13.5 & 12.5 & 10.4 & 8.6 & 10.8 & 12.2 & 16.7 & 13.4 & 14.7 \\
\hline V & 74 & 72 & 71 & 88 & 66 & 60 & 95 & 84 & 77 \\
\hline $\mathrm{Nb}$ & 0.562 & 0.316 & 0.346 & 0.606 & 0.511 & 0.549 & 1.061 & 0.813 & 0.958 \\
\hline Ta & 0.029 & 0.01 & 0.02 & 0.046 & 0.029 & 0.041 & 0.055 & 0.059 & 0.064 \\
\hline $\mathrm{Zr}$ & 11 & 9 & 8 & 14 & 9 & 13 & 14 & 21 & 14 \\
\hline $\mathrm{Hf}$ & 0.26 & 0.24 & 0.22 & 0.34 & 0.21 & 0.37 & 0.34 & 0.47 & 0.34 \\
\hline Th & 0.07 & 0.04 & 0.12 & 0.11 & 0.04 & 0.04 & 0.18 & 0.10 & 0.11 \\
\hline$U$ & 0.03 & 0.03 & 0.04 & 0.04 & 0.02 & 0.02 & 0.06 & 0.03 & 0.04 \\
\hline$Y$ & 2.94 & 2.56 & 2.74 & 3.49 & 1.83 & 2.75 & 3.45 & 3.17 & 3.24 \\
\hline La & 0.72 & 0.68 & 0.52 & 0.87 & 0.44 & 1.04 & 1.25 & 1.51 & 1.26 \\
\hline $\mathrm{Ce}$ & 1.43 & 0.96 & 1.02 & 2.07 & 1.02 & 2.92 & 2.37 & 3.79 & 2.55 \\
\hline $\mathrm{Pr}$ & 0.21 & 0.15 & 0.13 & 0.28 & 0.14 & 0.43 & 0.30 & 0.51 & 0.32 \\
\hline $\mathrm{Nd}$ & 0.97 & 0.74 & 0.63 & 1.32 & 0.64 & 1.82 & 1.3 & 2.16 & 1.35 \\
\hline Sm & 0.28 & 0.23 & 0.23 & 0.39 & 0.17 & 0.44 & 0.33 & 0.51 & 0.33 \\
\hline Eu & 0.11 & 0.09 & 0.09 & 0.14 & 0.07 & 0.15 & 0.13 & 0.18 & 0.13 \\
\hline $\mathrm{Gd}$ & 0.39 & 0.33 & 0.34 & 0.51 & 0.25 & 0.47 & 0.48 & 0.54 & 0.43 \\
\hline $\mathrm{Tb}$ & 0.07 & 0.06 & 0.06 & 0.09 & 0.04 & 0.08 & 0.09 & 0.09 & 0.08 \\
\hline Dy & 0.50 & 0.43 & 0.47 & 0.67 & 0.30 & 0.49 & 0.57 & 0.58 & 0.53 \\
\hline Ho & 0.10 & 0.10 & 0.10 & 0.14 & 0.06 & 0.10 & 0.12 & 0.12 & 0.11 \\
\hline $\mathrm{Er}$ & 0.33 & 0.29 & 0.32 & 0.43 & 0.21 & 0.29 & 0.39 & 0.37 & 0.35 \\
\hline $\mathrm{Tm}$ & 0.05 & 0.04 & 0.05 & 0.06 & 0.03 & 0.04 & 0.06 & 0.05 & 0.05 \\
\hline $\mathrm{Yb}$ & 0.32 & 0.28 & 0.32 & 0.40 & 0.22 & 0.29 & 0.37 & 0.36 & 0.35 \\
\hline Lu & 0.05 & 0.04 & 0.05 & 0.06 & 0.03 & 0.05 & 0.06 & 0.05 & 0.06 \\
\hline $\mathrm{Cu}$ & 12.1 & 11.9 & 14 & 15.4 & 7.7 & 5.6 & 13.8 & 9.8 & 17.3 \\
\hline $\mathrm{Zn}$ & 55 & 52 & 52 & 66 & 50 & 54 & 57 & 57 & 53 \\
\hline $\mathrm{Ga}$ & 3.25 & 2.85 & 2.8 & 3.8 & 2.32 & 3.46 & 3.9 & 3.89 & 3.36 \\
\hline $\mathrm{Pb}$ & & & 0.2 & 0.2 & & 0.2 & 0.3 & & \\
\hline $\mathrm{La} / \mathrm{Sm}_{\mathrm{cn}}$ & 1.66 & 1.92 & 1.47 & 1.44 & 1.71 & 1.53 & 2.42 & 1.90 & 2.45 \\
\hline $\mathrm{La} / \mathrm{Yb}_{\mathrm{cn}}$ & 1.64 & 1.73 & 1.17 & 1.58 & 1.42 & 2.55 & 2.42 & 3.04 & 2.58 \\
\hline $\mathrm{Gd} / \mathrm{Yb}_{\mathrm{cn}}$ & 1.03 & 0.97 & 0.87 & 1.07 & 0.94 & 1.32 & 1.07 & 1.26 & 1.00 \\
\hline $\mathrm{Eu} / \mathrm{Eu}_{\mathrm{cn}}{ }$ & 1.01 & 0.99 & 1.01 & 0.96 & 1.05 & 1.03 & 1.03 & 1.04 & 1.04 \\
\hline $\mathrm{Ce} / \mathrm{Ce}^{*}{ }_{\mathrm{cn}}$ & 0.90 & 0.74 & 0.95 & 1.02 & 1.01 & 1.08 & 0.95 & 1.06 & 0.98 \\
\hline $\mathrm{Al}_{2} \mathrm{O}_{3} / \mathrm{TiO}_{2}$ & 31 & 27 & 33 & 31 & 32 & 23 & 27 & 21 & 32 \\
\hline $\mathrm{CaO} / \mathrm{Al}_{2} \mathrm{O}_{3}$ & 0.79 & 0.89 & 0.85 & 0.82 & 0.79 & 0.79 & 0.81 & 0.83 & 0.83 \\
\hline $\mathrm{Nb} / \mathrm{Ta}$ & 19 & 32 & 17 & 13 & 18 & 13 & 19 & 14 & 15 \\
\hline $\mathrm{Zr} / \mathrm{Hf}$ & 42 & 38 & 36 & 41 & 43 & 35 & 41 & 45 & 41 \\
\hline $\mathrm{Pb} / \mathrm{Pb}^{*}{ }_{\text {MORB }}$ & & & 6 & 3 & & 2 & 4 & & \\
\hline $\mathrm{Nb} / \mathrm{Nb}^{*}{ }_{\text {MORB }}$ & 0.89 & 0.45 & 0.30 & 0.54 & 0.90 & 0.63 & 0.62 & 0.58 & 0.74 \\
\hline $\mathrm{Zr} / \mathrm{Zr}^{*}{ }_{\text {MORB }}$ & 1.39 & 1.39 & 1.22 & 1.33 & 1.85 & 1.11 & 1.46 & 1.53 & 1.51 \\
\hline $\mathrm{Ti} / \mathrm{Ti}^{*}{ }_{\text {MORB }}$ & 0.87 & 0.95 & 0.87 & 0.86 & 0.90 & 0.77 & 0.86 & 0.78 & 0.79 \\
\hline
\end{tabular}


Table 1. Continued

\begin{tabular}{|c|c|c|c|c|}
\hline \multicolumn{3}{|c|}{ Group 3} & \multicolumn{2}{|l|}{ Outliers } \\
\hline & TA-2012-48 & TA-2012-55 & TA-2012-14 & TA-2012-25 \\
\hline $\mathrm{SiO}_{2}$ & 44.3 & 44.3 & 43.6 & 43.0 \\
\hline $\mathrm{TiO}_{2}$ & 0.125 & 0.099 & 0.033 & 0.017 \\
\hline $\mathrm{Al}_{2} \mathrm{O}_{3}$ & 3.54 & 2.97 & 2.37 & 0.85 \\
\hline $\mathrm{Fe}_{2} \mathrm{O}_{3}$ & 9.31 & 9.48 & 8.78 & 8.18 \\
\hline $\mathrm{MnO}$ & 0.14 & 0.14 & 0.13 & 0.12 \\
\hline MgO & 39.9 & 41.4 & 42.7 & 47.1 \\
\hline $\mathrm{CaO}$ & 2.92 & 2.31 & 2.12 & 0.61 \\
\hline $\mathrm{K}_{2} \mathrm{O}$ & 0.03 & 0.03 & 0.07 & 0.03 \\
\hline $\mathrm{Na}_{2} \mathrm{O}$ & 0.32 & 0.26 & 0.26 & 0.11 \\
\hline $\mathrm{P}_{2} \mathrm{O}_{5}$ & 0.02 & 0.02 & 0.04 & 0.03 \\
\hline LOI & -0.62 & -0.64 & -0.6 & -0.57 \\
\hline Total & 100.0 & 100.3 & 99.5 & 99.5 \\
\hline Mg-mumber & 89.5 & 89.6 & 90.6 & 91.9 \\
\hline $\mathrm{Cr}$ & 2586 & 2384 & 2899 & 2931 \\
\hline Co & 102 & 112 & 111 & 122 \\
\hline $\mathrm{Ni}$ & 1927 & 2078 & 2141 & 2505 \\
\hline $\mathrm{Rb}$ & 0.63 & 0.52 & 1.24 & 0.76 \\
\hline $\mathrm{Sr}$ & 25.8 & 16.2 & 13.9 & 11.5 \\
\hline $\mathrm{Ba}$ & 8 & 3.1 & 10.3 & 2.8 \\
\hline Sc & 13.8 & 6.3 & 12.9 & 7.5 \\
\hline V & 78 & 64 & 72 & 41 \\
\hline $\mathrm{Nb}$ & 1.058 & 0.485 & 0.486 & 0.309 \\
\hline Ta & 0.069 & 0.033 & 0.035 & 0.021 \\
\hline $\mathrm{Zr}$ & 14 & 11 & 11 & 9 \\
\hline $\mathrm{Hf}$ & 0.3 & 0.27 & 0.21 & 0.15 \\
\hline Th & 0.09 & 0.04 & 0.20 & 0.11 \\
\hline U & 0.03 & 0.02 & 0.06 & 0.03 \\
\hline Y & 3.32 & 2.31 & 1.29 & 0.44 \\
\hline La & 1.54 & 0.85 & 0.7 & 1.03 \\
\hline $\mathrm{Ce}$ & 3.72 & 2.27 & 1.17 & 1.83 \\
\hline $\operatorname{Pr}$ & 0.51 & 0.34 & 0.10 & 0.18 \\
\hline $\mathrm{Nd}$ & 2.09 & 1.49 & 0.34 & 0.66 \\
\hline Sm & 0.46 & 0.34 & 0.08 & 0.10 \\
\hline $\mathrm{Eu}$ & 0.16 & 0.12 & 0.03 & 0.03 \\
\hline $\mathrm{Gd}$ & 0.50 & 0.39 & 0.12 & 0.09 \\
\hline $\mathrm{Tb}$ & 0.08 & 0.06 & 0.02 & 0.01 \\
\hline Dy & 0.57 & 0.43 & 0.19 & 0.07 \\
\hline Ho & 0.12 & 0.09 & 0.05 & 0.01 \\
\hline $\mathrm{Er}$ & 0.37 & 0.28 & 0.14 & 0.05 \\
\hline $\mathrm{Tm}$ & 0.05 & 0.04 & 0.02 & 0.01 \\
\hline $\mathrm{Yb}$ & 0.35 & 0.26 & 0.18 & 0.05 \\
\hline Lu & 0.05 & 0.04 & 0.03 & 0.01 \\
\hline $\mathrm{Cu}$ & 8.7 & 12.6 & 9 & 4.4 \\
\hline $\mathrm{Zn}$ & 64 & 65 & 52 & 51 \\
\hline $\mathrm{Ga}$ & 3.34 & 2.7 & 2.15 & 1.14 \\
\hline $\mathrm{Pb}$ & & 0.2 & 0.2 & 0.2 \\
\hline $\mathrm{La} / \mathrm{Sm}_{\mathrm{cn}}$ & 2.17 & 1.60 & 5.65 & 6.65 \\
\hline $\mathrm{La} / \mathrm{Yb}_{\mathrm{cn}}$ & 3.17 & 2.33 & 2.81 & 15.08 \\
\hline $\mathrm{Gd} / \mathrm{Yb}_{\mathrm{cn}}$ & 1.19 & 1.23 & 0.55 & 1.57 \\
\hline $\mathrm{Eu} / \mathrm{Eu}^{*}{ }_{\mathrm{cn}}$ & 0.99 & 1.03 & 1.02 & 1.11 \\
\hline $\mathrm{Ce} / \mathrm{Ce}^{*}{ }_{\mathrm{cn}}$ & 1.03 & 1.04 & 1.08 & 1.03 \\
\hline $\mathrm{Al}_{2} \mathrm{O}_{3} / \mathrm{TiO}_{2}$ & 28 & 30 & 72 & 50 \\
\hline $\mathrm{CaO} / \mathrm{Al}_{2} \mathrm{O}_{3}$ & 0.82 & 0.78 & 0.89 & 0.72 \\
\hline $\mathrm{Nb} / \mathrm{Ta}$ & 15 & 15 & 14 & 15 \\
\hline $\mathrm{Zr} / \mathrm{Hf}$ & 47 & 41 & 52 & 60 \\
\hline $\mathrm{Pb} / \mathrm{Pb}^{*}{ }_{\text {MORB }}$ & & 2 & 6 & 4 \\
\hline $\mathrm{Nb} / \mathrm{Nb}^{*}{ }_{\text {MORB }}$ & 0.83 & 0.50 & 0.18 & 0.25 \\
\hline $\mathrm{Zr} / \mathrm{Zr}^{*}{ }_{\mathrm{MORB}}$ & 1.16 & 1.18 & 4.78 & 3.37 \\
\hline $\mathrm{Ti} / \mathrm{Ti}^{*}{ }_{\text {MORB }}$ & 0.68 & 0.69 & 0.81 & 0.46 \\
\hline
\end{tabular}


Table 2. Whole-rock major (wt.\%) and trace (ppm) element concentrations and significant element ratios for alkaline basalts.

\begin{tabular}{|c|c|c|c|c|c|c|c|c|c|}
\hline & TA-2012-26 & TA-2012-27 & TA-2012-29 & TA-2012-30 & TA-2012-31 & TA-2012-33 & TA-2012-34 & TA-2012-35 & TA-2012-37 \\
\hline $\mathrm{SiO}_{2}$ & 45.8 & 45.4 & 45.5 & 45.3 & 45.2 & 45.5 & 45.4 & 45.1 & 45.7 \\
\hline $\mathrm{TiO}_{2}$ & 2.55 & 2.56 & 2.62 & 2.53 & 2.57 & 2.59 & 2.54 & 2.56 & 2.70 \\
\hline $\mathrm{Al}_{2} \mathrm{O}_{3}$ & 13.4 & 14.2 & 13.8 & 13.6 & 13.7 & 13.6 & 13.6 & 13.4 & 14.2 \\
\hline $\mathrm{Fe}_{2} \mathrm{O}_{3}$ & 14.3 & 14.4 & 14.2 & 14.0 & 14.2 & 14.1 & 14.3 & 14.0 & 14.6 \\
\hline $\mathrm{MnO}$ & 0.193 & 0.191 & 0.192 & 0.19 & 0.19 & 0.191 & 0.19 & 0.188 & 0.194 \\
\hline MgO & 10.24 & 9.27 & 9.39 & 9.59 & 9.53 & 9.59 & 9.84 & 9.35 & 7.99 \\
\hline $\mathrm{CaO}$ & 7.82 & 7.85 & 7.73 & 7.65 & 7.77 & 7.76 & 7.75 & 7.81 & 8.01 \\
\hline $\mathrm{K}_{2} \mathrm{O}$ & 1.71 & 1.74 & 1.69 & 1.74 & 1.72 & 1.69 & 1.7 & 1.7 & 1.91 \\
\hline $\mathrm{Na}_{2} \mathrm{O}$ & 3.97 & 4.22 & 4.05 & 4.15 & 4.14 & 4.03 & 3.99 & 4.1 & 4.32 \\
\hline $\mathrm{P}_{2} \mathrm{O}_{5}$ & 0.8 & 0.82 & 0.81 & 0.82 & 0.8 & 0.82 & 0.78 & 0.8 & 0.9 \\
\hline LOI & -0.29 & -0.64 & -0.29 & -0.62 & -0.57 & -0.4 & -0.52 & -0.66 & -0.38 \\
\hline Total & 100.5 & 100 & 99.69 & 98.99 & 99.22 & 99.43 & 99.52 & 98.27 & 100.1 \\
\hline Mg-number & 58.7 & 56.1 & 56.6 & 57.5 & 57.1 & 57.3 & 57.7 & 56.9 & 52.1 \\
\hline $\mathrm{Cr}$ & 387 & 338 & 345 & 377 & 357 & 340 & 354 & 363 & 260 \\
\hline Co & 53 & 51 & 51 & 51 & 49 & 49 & 51 & 52 & 47 \\
\hline $\mathrm{Ni}$ & 318 & 263 & 276 & 289 & 276 & 275 & 301 & 281 & 198 \\
\hline $\mathrm{Rb}$ & 37 & 38 & 39 & 37 & 36 & 36 & 36 & 37 & 40 \\
\hline $\mathrm{Sr}$ & 933 & 907 & 906 & 882 & 881 & 880 & 883 & 886 & 965 \\
\hline Cs & 0.46 & 0.53 & 0.60 & 0.55 & 0.54 & 0.46 & 0.54 & 0.52 & 0.48 \\
\hline $\mathrm{Ba}$ & 719 & 734 & 755 & 732 & 737 & 723 & 716 & 725 & 797 \\
\hline Sc & 16 & 15 & 15 & 14 & 15 & 14 & 15 & 16 & 14 \\
\hline V & 161 & 157 & 152 & 146 & 146 & 148 & 152 & 161 & 151 \\
\hline $\mathrm{Nb}$ & 71 & 72 & 72 & 71 & 71 & 70 & 69 & 70 & 76 \\
\hline $\mathrm{Ta}$ & 4.07 & 4.09 & 4.09 & 4.09 & 4.10 & 4.08 & 3.96 & 3.98 & 4.33 \\
\hline $\mathrm{Zr}$ & 328 & 324 & 324 & 319 & 317 & 314 & 309 & 315 & 342 \\
\hline $\mathrm{Hf}$ & 6.81 & 6.79 & 6.83 & 6.67 & 6.81 & 6.75 & 6.63 & 6.66 & 7.20 \\
\hline Th & 5.75 & 5.92 & 6.03 & 5.90 & 5.94 & 5.92 & 5.73 & 5.70 & 6.40 \\
\hline$U$ & 1.61 & 1.65 & 1.69 & 1.68 & 1.68 & 1.67 & 1.60 & 1.68 & 1.69 \\
\hline Y & 26 & 25 & 25 & 25 & 24 & 24 & 24 & 25 & 26 \\
\hline La & 49 & 51 & 52 & 51 & 51 & 51 & 50 & 50 & 55 \\
\hline $\mathrm{Ce}$ & 99 & 101 & 104 & 102 & 101 & 99 & 99 & 100 & 110 \\
\hline $\mathrm{Pr}$ & 12 & 12 & 12 & 12 & 12 & 12 & 12 & 12 & 13 \\
\hline $\mathrm{Nd}$ & 46 & 48 & 49 & 48 & 49 & 47 & 47 & 48 & 53 \\
\hline Sm & 8.84 & 8.97 & 9.17 & 8.86 & 9.07 & 8.90 & 8.80 & 8.89 & 9.57 \\
\hline $\mathrm{Eu}$ & 2.77 & 2.86 & 2.88 & 2.83 & 2.81 & 2.88 & 2.79 & 2.84 & 3.01 \\
\hline $\mathrm{Gd}$ & 7.34 & 7.65 & 7.74 & 7.54 & 7.66 & 7.54 & 7.38 & 7.66 & 7.94 \\
\hline $\mathrm{Tb}$ & 0.97 & 1.02 & 1.04 & 1.02 & 1.01 & 1.03 & 1.00 & 1.02 & 1.06 \\
\hline Dy & 5.35 & 5.63 & 5.55 & 5.48 & 5.42 & 5.43 & 5.34 & 5.47 & 5.74 \\
\hline Ho & 0.91 & 0.95 & 0.94 & 0.94 & 0.94 & 0.92 & 0.92 & 0.94 & 0.98 \\
\hline $\mathrm{Er}$ & 2.37 & 2.37 & 2.39 & 2.38 & 2.37 & 2.35 & 2.29 & 2.38 & 2.47 \\
\hline $\mathrm{Tm}$ & 0.29 & 0.30 & 0.30 & 0.30 & 0.30 & 0.30 & 0.29 & 0.30 & 0.31 \\
\hline $\mathrm{Yb}$ & 1.75 & 1.75 & 1.79 & 1.75 & 1.77 & 1.74 & 1.72 & 1.73 & 1.85 \\
\hline Lu & 0.24 & 0.24 & 0.25 & 0.24 & 0.24 & 0.25 & 0.24 & 0.24 & 0.26 \\
\hline $\mathrm{Cu}$ & 41 & 41 & 40 & 39 & 39 & 37 & 34 & 40 & 38 \\
\hline $\mathrm{Zn}$ & 122 & 119 & 120 & 116 & 116 & 115 & 115 & 117 & 122 \\
\hline $\mathrm{Ga}$ & 22 & 21 & 21 & 21 & 21 & 20 & 21 & 21 & 22 \\
\hline $\mathrm{Pb}$ & 3.2 & 3.1 & 3.2 & 3.1 & 3.1 & 3.1 & 3 & 3.1 & 3.4 \\
\hline $\mathrm{La} / \mathrm{Sm}_{\mathrm{cn}}$ & 3.61 & 3.68 & 3.67 & 3.74 & 3.64 & 3.69 & 3.65 & 3.66 & 3.72 \\
\hline $\mathrm{La} / \mathrm{Yb}_{\mathrm{cn}}$ & 20.3 & 21.0 & 20.9 & 21.0 & 20.7 & 21.1 & 20.7 & 20.9 & 21.4 \\
\hline $\mathrm{Gd} / \mathrm{Yb}_{\mathrm{cn}}$ & 3.47 & 3.62 & 3.57 & 3.56 & 3.58 & 3.60 & 3.54 & 3.67 & 3.56 \\
\hline $\mathrm{Eu} / \mathrm{Eu}^{*}{ }_{\mathrm{cn}}$ & 1.05 & 1.05 & 1.04 & 1.06 & 1.03 & 1.07 & 1.06 & 1.05 & 1.06 \\
\hline $\mathrm{Ce} / \mathrm{Ce}^{*}{ }_{\mathrm{cn}}$ & 1.00 & 1.00 & 1.00 & 1.00 & 0.99 & 0.98 & 0.99 & 0.99 & 1.00 \\
\hline $\mathrm{Al}_{2} \mathrm{O}_{3} / \mathrm{TiO}_{2}$ & 5.3 & 5.6 & 5.3 & 5.4 & 5.3 & 5.2 & 5.4 & 5.2 & 5.3 \\
\hline $\mathrm{K}_{2} \mathrm{O}+\mathrm{Na}_{2} \mathrm{O}$ & 5.7 & 6.0 & 5.7 & 5.9 & 5.9 & 5.7 & 5.7 & 5.8 & 6.2 \\
\hline $\mathrm{Zr} / \mathrm{Y}$ & 12.8 & 12.9 & 12.9 & 12.8 & 13.0 & 12.8 & 12.9 & 12.8 & 13.1 \\
\hline $\mathrm{Nb} / \mathrm{Y}$ & 2.8 & 2.9 & 2.9 & 2.9 & 2.9 & 2.9 & 2.9 & 2.8 & 2.9 \\
\hline $\mathrm{Nb} / \mathrm{Ta}$ & 17 & 18 & 18 & 17 & 17 & 17 & 17 & 18 & 18 \\
\hline $\mathrm{Zr} / \mathrm{Hf}$ & 48 & 48 & 47 & 48 & 47 & 47 & 47 & 47 & 48 \\
\hline $\mathrm{Y} / \mathrm{Ho}$ & 28 & 26 & 27 & 26 & 26 & 27 & 26 & 26 & 27 \\
\hline $\mathrm{Pb} / \mathrm{Pb}^{*}{ }_{\text {MORB }}$ & 1.0 & 0.9 & 0.9 & 0.9 & 0.9 & 0.9 & 0.9 & 0.9 & 0.9 \\
\hline $\mathrm{Nb} / \mathrm{Nb}^{*}{ }_{\text {MORB }}$ & 1.07 & 1.06 & 1.07 & 1.04 & 1.04 & 1.04 & 1.05 & 1.03 & 1.07 \\
\hline $\mathrm{Zr} / \mathrm{Zr}{ }^{*}{ }_{\mathrm{MORB}}$ & 1.47 & 1.42 & 1.40 & 1.41 & 1.39 & 1.37 & 1.38 & 1.39 & 1.41 \\
\hline $\mathrm{Ti} / \mathrm{Ti}^{*}{ }_{\text {MORB }}$ & 0.86 & 0.84 & 0.85 & 0.84 & 0.85 & 0.85 & 0.86 & 0.84 & 0.84 \\
\hline
\end{tabular}

MORB: Normal Mid-Ocean Ridge Basalt; $\mathrm{cn}$ : Chondite. $\mathrm{Pb} / \mathrm{Pb} *$ values were calculated relative to $\mathrm{Ce}$ and $\mathrm{Pr}$.

$\mathrm{Nb} / \mathrm{Nb}^{*}$ values were calculated relative to $\mathrm{U}$ and $\mathrm{K}$. $\mathrm{Zr} / \mathrm{Zr}$ * values were calculated relative to $\mathrm{Sm}$ and $\mathrm{Eu}$

$\mathrm{Ti} / \mathrm{Ti}^{*}$ values were calculated relative to $\mathrm{Eu}$ and $\mathrm{Gd}$ 
Table 2. Continued.

\begin{tabular}{|c|c|c|c|c|c|c|c|c|c|}
\hline & TA-2012-38 & TA-2012-39 & TA-2012-41 & TA-2012-42 & TA-2012-43 & TA-2012-47 & TA-2012-50 & TA-2012-52 & TA-2012-53 \\
\hline $\mathrm{SiO}_{2}$ & 46.0 & 45.7 & 44.6 & 44.7 & 45.4 & 45.2 & 45.1 & 44.8 & 44.9 \\
\hline $\mathrm{TiO}_{2}$ & 2.54 & 2.59 & 2.60 & 2.48 & 2.55 & 2.55 & 3.10 & 3.13 & 2.51 \\
\hline $\mathrm{Al}_{2} \mathrm{O}_{3}$ & 13.4 & 14.3 & 13.6 & 13.6 & 13.9 & 13.8 & 14.3 & 14.8 & 14.0 \\
\hline $\mathrm{Fe}_{2} \mathrm{O}_{3}$ & 14.2 & 14.5 & 14.1 & 13.7 & 14.1 & 13.9 & 14.7 & 14.6 & 13.9 \\
\hline $\mathrm{MnO}$ & 0.191 & 0.192 & 0.191 & 0.191 & 0.197 & 0.194 & 0.182 & 0.185 & 0.19 \\
\hline $\mathrm{MgO}$ & 9.84 & 9.27 & 9.41 & 8.51 & 8.57 & 8.25 & 6.98 & 6.51 & 8.82 \\
\hline $\mathrm{CaO}$ & 7.88 & 7.84 & 8.09 & 7.89 & 7.71 & 7.68 & 8.32 & 8.26 & 7.59 \\
\hline $\mathrm{K}_{2} \mathrm{O}$ & 1.78 & 1.81 & 1.73 & 1.89 & 1.91 & 1.91 & 2 & 2.11 & 1.75 \\
\hline $\mathrm{Na}_{2} \mathrm{O}$ & 4.16 & 4.11 & 3.72 & 3.97 & 4.4 & 4.42 & 4.21 & 4.51 & 4.29 \\
\hline $\mathrm{P}_{2} \mathrm{O}_{5}$ & 0.8 & 0.81 & 0.83 & 0.9 & 0.91 & 0.91 & 0.84 & 0.93 & 0.8 \\
\hline LOI & -0.62 & -0.48 & 0.56 & 0.56 & -0.41 & -0.43 & 0.77 & 0.61 & 0.08 \\
\hline Total & 100.3 & 100.6 & 99.38 & 98.42 & 99.21 & 98.4 & 100.4 & 100.4 & 98.85 \\
\hline Mg-number & 57.8 & 55.9 & 57.0 & 55.1 & 54.7 & 54.1 & 48.5 & 46.9 & 55.7 \\
\hline $\mathrm{Cr}$ & 408 & 343 & 364 & 299 & 307 & 288 & 179 & 161 & 351 \\
\hline Co & 51 & 50 & 50 & 48 & 48 & 46 & 49 & 47 & 48 \\
\hline $\mathrm{Ni}$ & 289 & 267 & 268 & 233 & 231 & 213 & 134 & 108 & 255 \\
\hline $\mathrm{Rb}$ & 37 & 39 & 38 & 43 & 42 & 42 & 47 & 49 & 48 \\
\hline $\mathrm{Sr}$ & 878 & 890 & 876 & 928 & 948 & 962 & 940 & 993 & 884 \\
\hline Cs & 0.50 & 0.48 & 0.54 & 0.60 & 0.58 & 0.57 & 0.61 & 0.67 & 0.58 \\
\hline $\mathrm{Ba}$ & 714 & 739 & 726 & 778 & 794 & 792 & 581 & 636 & 751 \\
\hline Sc & 15 & 15 & 15 & 14 & 14 & 14 & 14 & 13 & 14 \\
\hline V & 152 & 152 & 152 & 145 & 148 & 144 & 187 & 181 & 140 \\
\hline $\mathrm{Nb}$ & 69 & 72 & 70 & 75 & 76 & 77 & 68 & 76 & 72 \\
\hline $\mathrm{Ta}$ & 4.02 & 4.14 & 3.99 & 4.36 & 4.37 & 4.54 & 4.11 & 4.60 & 4.21 \\
\hline $\mathrm{Zr}$ & 312 & 329 & 317 & 346 & 345 & 357 & 351 & 383 & 323 \\
\hline $\mathrm{Hf}$ & 6.64 & 6.89 & 6.66 & 7.22 & 7.25 & 7.51 & 7.47 & 8.02 & 6.96 \\
\hline Th & 5.63 & 5.93 & 5.74 & 6.49 & 6.44 & 6.50 & 4.98 & 5.67 & 6.21 \\
\hline U & 1.57 & 1.56 & 1.62 & 1.83 & 1.82 & 1.82 & 1.48 & 1.78 & 1.78 \\
\hline Y & 25 & 26 & 25 & 26 & 26 & 27 & 25 & 25 & 25 \\
\hline La & 49 & 51 & 50 & 55 & 56 & 56 & 46 & 52 & 52 \\
\hline $\mathrm{Ce}$ & 99 & 102 & 101 & 109 & 110 & 111 & 95 & 107 & 104 \\
\hline $\mathrm{Pr}$ & 12 & 12 & 12 & 13 & 13 & 13 & 12 & 13 & 12 \\
\hline $\mathrm{Nd}$ & 47 & 48 & 47 & 50 & 51 & 51 & 47 & 52 & 49 \\
\hline Sm & 8.84 & 9.00 & 8.80 & 9.31 & 9.34 & 9.58 & 9.48 & 10.06 & 9.18 \\
\hline $\mathrm{Eu}$ & 2.79 & 2.84 & 2.78 & 2.90 & 2.94 & 2.96 & 3.04 & 3.15 & 2.90 \\
\hline $\mathrm{Gd}$ & 7.27 & 7.43 & 7.28 & 7.77 & 7.71 & 7.83 & 8.02 & 8.32 & 7.72 \\
\hline $\mathrm{Tb}$ & 0.99 & 1.00 & 0.97 & 1.02 & 1.03 & 1.07 & 1.05 & 1.12 & 1.03 \\
\hline Dy & 5.35 & 5.54 & 5.27 & 5.55 & 5.49 & 5.72 & 5.59 & 5.75 & 5.48 \\
\hline Ho & 0.92 & 0.94 & 0.92 & 0.95 & 0.95 & 0.98 & 0.92 & 0.95 & 0.94 \\
\hline $\mathrm{Er}$ & 2.36 & 2.43 & 2.34 & 2.41 & 2.43 & 2.51 & 2.20 & 2.23 & 2.39 \\
\hline $\mathrm{Tm}$ & 0.29 & 0.30 & 0.29 & 0.31 & 0.30 & 0.32 & 0.26 & 0.27 & 0.30 \\
\hline $\mathrm{Yb}$ & 1.72 & 1.76 & 1.69 & 1.79 & 1.80 & 1.83 & 1.48 & 1.49 & 1.76 \\
\hline Lu & 0.24 & 0.25 & 0.23 & 0.25 & 0.25 & 0.25 & 0.19 & 0.19 & 0.25 \\
\hline $\mathrm{Cu}$ & 39 & 51 & 39 & 38 & 38 & 34 & 49 & 44 & 43 \\
\hline $\mathrm{Zn}$ & 123 & 126 & 124 & 129 & 131 & 131 & 149 & 164 & 124 \\
\hline $\mathrm{Ga}$ & 20 & 21 & 21 & 21 & 22 & 22 & 25 & 25 & 21 \\
\hline $\mathrm{Pb}$ & 3 & 3.2 & 3.1 & 3.4 & 3.4 & 3.5 & 3.3 & 3.5 & 3.5 \\
\hline $\mathrm{La} / \mathrm{Sm}_{\mathrm{cn}}$ & 3.61 & 3.67 & 3.66 & 3.80 & 3.85 & 3.78 & 3.15 & 3.37 & 3.68 \\
\hline $\mathrm{La} / \mathrm{Yb}_{\mathrm{cn}}$ & 20.6 & 20.9 & 21.2 & 21.9 & 22.2 & 21.9 & 22.3 & 25.2 & 21.3 \\
\hline $\mathrm{Gd} / \mathrm{Yb}_{\mathrm{cn}}$ & 3.49 & 3.49 & 3.57 & 3.58 & 3.54 & 3.54 & 4.48 & 4.61 & 3.63 \\
\hline $\mathrm{Eu} / \mathrm{Eu}^{*}{ }_{\mathrm{cn}}$ & 1.06 & 1.06 & 1.06 & 1.04 & 1.06 & 1.04 & 1.07 & 1.05 & 1.05 \\
\hline $\mathrm{Ce} / \mathrm{Ce}^{*}{ }_{\mathrm{cn}}$ & 1.00 & 1.01 & 1.01 & 1.01 & 1.01 & 1.00 & 1.01 & 1.00 & 1.00 \\
\hline $\mathrm{Al}_{2} \mathrm{O}_{3} / \mathrm{TiO}_{2}$ & 5.3 & 5.5 & 5.2 & 5.5 & 5.4 & 5.4 & 4.6 & 4.7 & 5.6 \\
\hline $\mathrm{K}_{2} \mathrm{O}+\mathrm{Na}_{2} \mathrm{O}$ & 5.9 & 5.9 & 5.5 & 5.9 & 6.3 & 6.3 & 6.2 & 6.6 & 6.0 \\
\hline $\mathrm{Zr} / \mathrm{Y}$ & 12.6 & 12.7 & 12.7 & 13.3 & 13.2 & 13.3 & 14.1 & 15.0 & 13.0 \\
\hline $\mathrm{Nb} / \mathrm{Y}$ & 2.8 & 2.8 & 2.8 & 2.9 & 2.9 & 2.9 & 2.7 & 3.0 & 2.9 \\
\hline $\mathrm{Nb} / \mathrm{Ta}$ & 17 & 17 & 17 & 17 & 17 & 17 & 17 & 17 & 17 \\
\hline $\mathrm{Zr} / \mathrm{Hf}$ & 47 & 48 & 48 & 48 & 48 & 48 & 47 & 48 & 46 \\
\hline $\mathrm{Y} / \mathrm{Ho}$ & 27 & 28 & 27 & 27 & 27 & 27 & 27 & 27 & 26 \\
\hline $\mathrm{Pb} / \mathrm{Pb}^{*}{ }_{\text {MORB }}$ & 0.9 & 1.0 & 0.9 & 1.0 & 0.9 & 1.0 & 1.0 & 1.0 & 1.0 \\
\hline $\mathrm{Nb} / \mathrm{Nb}^{*}{ }_{\mathrm{MORB}}$ & 1.04 & 1.08 & 1.04 & 1.01 & 1.02 & 1.03 & 0.99 & 0.98 & 1.03 \\
\hline $\mathrm{Zr} / \mathrm{Zr}{ }^{*}{ }_{\text {MORB }}$ & 1.39 & 1.44 & 1.42 & 1.47 & 1.46 & 1.48 & 1.45 & 1.51 & 1.38 \\
\hline $\mathrm{Ti} / \mathrm{Ti}^{*}{ }_{\text {MORB }}$ & 0.86 & 0.86 & 0.88 & 0.80 & 0.82 & 0.81 & 0.96 & 0.93 & 0.81 \\
\hline
\end{tabular}


Table 2. Continued.

\begin{tabular}{|c|c|c|c|c|c|}
\hline & TA-2012-54 & TA-2012-58 & TA-2012-59 & TA-2012-60 & TA-2012-61 \\
\hline $\mathrm{SiO}_{2}$ & 44.2 & 44.6 & 45.5 & 45.5 & 44.3 \\
\hline $\mathrm{TiO}_{2}$ & 2.38 & 2.90 & 2.96 & 2.89 & 2.81 \\
\hline $\mathrm{Al}_{2} \mathrm{O}_{3}$ & 13.5 & 14.6 & 14.7 & 15.0 & 13.8 \\
\hline $\mathrm{Fe}_{2} \mathrm{O}_{3}$ & 12.9 & 14.7 & 14.9 & 14.8 & 14.8 \\
\hline $\mathrm{MnO}$ & 0.19 & 0.188 & 0.19 & 0.192 & 0.186 \\
\hline $\mathrm{MgO}$ & 8.87 & 7.55 & 7.73 & 7.52 & 7.43 \\
\hline $\mathrm{CaO}$ & 7.46 & 8.45 & 8.59 & 8.43 & 8.37 \\
\hline $\mathrm{K}_{2} \mathrm{O}$ & 1.48 & 1.82 & 1.83 & 1.93 & 1.74 \\
\hline $\mathrm{Na}_{2} \mathrm{O}$ & 3.58 & 4.2 & 4.12 & 4.28 & 3.96 \\
\hline $\mathrm{P}_{2} \mathrm{O}_{5}$ & 0.81 & 0.79 & 0.76 & 0.85 & 0.76 \\
\hline LOI & 2.9 & -0.74 & -0.58 & -0.64 & 1.68 \\
\hline Total & 98.2 & 99.09 & 100.7 & 100.8 & 99.88 \\
\hline Mg-number & 57.7 & 50.5 & 50.7 & 50.1 & 49.8 \\
\hline $\mathrm{Cr}$ & 295 & 181 & 176 & 175 & 175 \\
\hline Co & 51 & 52 & 52 & 50 & 52 \\
\hline $\mathrm{Ni}$ & 256 & 129 & 124 & 121 & 125 \\
\hline $\mathrm{Rb}$ & 51 & 37 & 36 & 39 & 37 \\
\hline $\mathrm{Sr}$ & 887 & 890 & 873 & 923 & 874 \\
\hline Cs & 0.66 & 0.52 & 0.39 & 0.48 & 0.56 \\
\hline $\mathrm{Ba}$ & 763 & 721 & 700 & 742 & 710 \\
\hline Sc & 15 & 17 & 17 & 16 & 17 \\
\hline V & 105 & 182 & 183 & 172 & 182 \\
\hline $\mathrm{Nb}$ & 72 & 68 & 66 & 70 & 67 \\
\hline $\mathrm{Ta}$ & 4.18 & 3.91 & 3.81 & 4.05 & 3.87 \\
\hline $\mathrm{Zr}$ & 328 & 311 & 302 & 320 & 308 \\
\hline $\mathrm{Hf}$ & 6.88 & 6.78 & 6.51 & 6.89 & 6.72 \\
\hline Th & 6.29 & 5.42 & 5.33 & 5.75 & 5.44 \\
\hline$U$ & 1.58 & 1.54 & 1.51 & 1.59 & 1.49 \\
\hline$Y$ & 25 & 26 & 26 & 26 & 26 \\
\hline La & 53 & 49 & 47 & 51 & 48 \\
\hline $\mathrm{Ce}$ & 103 & 98 & 96 & 102 & 98 \\
\hline $\mathrm{Pr}$ & 12 & 12 & 12 & 13 & 12 \\
\hline $\mathrm{Nd}$ & 49 & 48 & 47 & 50 & 48 \\
\hline Sm & 8.93 & 9.16 & 8.94 & 9.19 & 9.14 \\
\hline $\mathrm{Eu}$ & 2.79 & 2.92 & 2.85 & 2.97 & 2.93 \\
\hline Gd & 7.30 & 7.92 & 7.77 & 7.96 & 7.86 \\
\hline $\mathrm{Tb}$ & 0.99 & 1.07 & 1.04 & 1.09 & 1.04 \\
\hline Dy & 5.38 & 5.66 & 5.55 & 5.64 & 5.68 \\
\hline Ho & 0.93 & 0.97 & 0.95 & 0.99 & 0.97 \\
\hline $\mathrm{Er}$ & 2.35 & 2.44 & 2.38 & 2.46 & 2.40 \\
\hline $\mathrm{Tm}$ & 0.30 & 0.30 & 0.30 & 0.30 & 0.30 \\
\hline $\mathrm{Yb}$ & 1.77 & 1.77 & 1.72 & 1.81 & 1.79 \\
\hline Lu & 0.24 & 0.25 & 0.24 & 0.24 & 0.25 \\
\hline $\mathrm{Cu}$ & 30 & 46 & 46 & 45 & 46 \\
\hline $\mathrm{Zn}$ & 136 & 126 & 125 & 127 & 127 \\
\hline $\mathrm{Ga}$ & 21 & 23 & 22 & 23 & 22 \\
\hline $\mathrm{Pb}$ & 2.3 & 3.2 & 3.1 & 3.4 & 3.2 \\
\hline $\mathrm{La} / \mathrm{Sm}_{\mathrm{cn}}$ & 3.80 & 3.44 & 3.41 & 3.58 & 3.40 \\
\hline $\mathrm{La} / \mathrm{Yb}_{\mathrm{cn}}$ & 21.3 & 19.8 & 19.7 & 20.3 & 19.3 \\
\hline $\mathrm{Gd} / \mathrm{Yb}_{\mathrm{cn}}$ & 3.42 & 3.71 & 3.74 & 3.65 & 3.63 \\
\hline $\mathrm{Eu} / \mathrm{Eu}^{*}{ }_{\mathrm{cn}}$ & 1.06 & 1.05 & 1.05 & 1.06 & 1.05 \\
\hline $\mathrm{Ce} / \mathrm{Ce}^{*}{ }_{\mathrm{cn}}$ & 0.99 & 0.99 & 1.00 & 0.99 & 1.00 \\
\hline $\mathrm{Al}_{2} \mathrm{O}_{3} / \mathrm{TiO}_{2}$ & 5.7 & 5.1 & 5.0 & 5.2 & 4.9 \\
\hline $\mathrm{K}_{2} \mathrm{O}+\mathrm{Na}_{2} \mathrm{O}$ & 5.1 & 6.0 & 6.0 & 6.2 & 5.7 \\
\hline $\mathrm{Zr} / \mathrm{Y}$ & 13.1 & 12.0 & 11.8 & 12.5 & 12.0 \\
\hline $\mathrm{Nb} / \mathrm{Y}$ & 2.9 & 2.6 & 2.6 & 2.7 & 2.6 \\
\hline $\mathrm{Nb} / \mathrm{Ta}$ & 17 & 17 & 17 & 17 & 17 \\
\hline $\mathrm{Zr} / \mathrm{Hf}$ & 48 & 46 & 46 & 46 & 46 \\
\hline $\mathrm{Y} / \mathrm{Ho}$ & 27 & 27 & 27 & 26 & 27 \\
\hline $\mathrm{Pb} / \mathrm{Pb}^{*}{ }_{\text {MORB }}$ & 0.7 & 1.0 & 1.0 & 1.0 & 1.0 \\
\hline $\mathrm{Nb} / \mathrm{Nb}^{*}{ }_{\text {MORB }}$ & 1.18 & 1.01 & 1.00 & 1.00 & 1.05 \\
\hline $\mathrm{Zr} / \mathrm{Zr}{ }^{*}{ }_{\text {MORB }}$ & 1.45 & 1.33 & 1.32 & 1.36 & 1.32 \\
\hline $\mathrm{Ti} / \mathrm{Ti}^{*}{ }_{\text {MORB }}$ & 0.81 & 0.92 & 0.96 & 0.91 & 0.90 \\
\hline
\end{tabular}


Table 3. Sr isotope data for the Tasse alkaline basalts

\begin{tabular}{lcccc}
\hline & $\mathrm{Rb}$ & $\mathrm{Sr}$ & ${ }^{87} \mathrm{Sr}{ }^{86} \mathrm{Sr}$ & ${ }^{87} \mathrm{Rb} /{ }^{86} \mathrm{Sr}$ \\
\cline { 2 - 5 } TA 2012-27 & 38 & 907 & $0.703416 \pm 11$ & 0.1225 \\
TA 2012-31 & 36 & 881 & $0.703382 \pm 12$ & 0.1185 \\
TA 2012-35 & 37 & 886 & $0.703393 \pm 11$ & 0.1197 \\
TA 2012-37 & 40 & 965 & $0.703409 \pm 09$ & 0.1191 \\
TA 2012-41 & 38 & 876 & $0.703346 \pm 12$ & 0.1269 \\
TA 2012-43 & 42 & 948 & $0.703347 \pm 11$ & 0.1269 \\
TA 2012-60 & 39 & 923 & $0.703591 \pm 11$ & 0.1226 \\
\hline
\end{tabular}


Table 4. Sm-Nd isotope composition of the Tasse alkaline basalts.

\begin{tabular}{|c|c|c|c|c|c|c|}
\hline & Sm (ppm) & $\mathrm{Nd}(\mathrm{ppm})$ & ${ }^{147} \mathrm{Sm} /{ }^{144} \mathrm{Nd}$ & ${ }^{143} \mathrm{Nd} /{ }^{144} \mathrm{Nd}$ & $\mathrm{T}_{\mathrm{DM}}(\mathrm{Ma})^{*}$ & $\varepsilon \mathrm{Nd}(0)$ \\
\hline TA 201227 & 8.752 & 47.818 & 0.1108 & $0.512863 \pm 06$ & 426 & 4.4 \\
\hline TA 201231 & 9.257 & 50.929 & 0.1100 & $0.512902 \pm 05$ & 366 & 5.1 \\
\hline TA 201235 & 9.107 & 49.335 & 0.1117 & $0.512834 \pm 09$ & 474 & 3.8 \\
\hline TA 201237 & 8.770 & 48.286 & 0.1099 & $0.512896 \pm 04$ & 374 & 5.0 \\
\hline TA 201241 & 9.076 & 49.780 & 0.1104 & $0.512922 \pm 06$ & 338 & 5.5 \\
\hline TA 201243 & 8.724 & 48.296 & 0.1093 & $0.512888 \pm 04$ & 384 & 4.9 \\
\hline TA 201260 & 8.251 & 44.949 & 0.1111 & $0.512912 \pm 05$ & 355 & 5.3 \\
\hline
\end{tabular}

*DePaolo (1981) 
Table 5. $\mathrm{Pb}$ isotopic compositions of the Tasse alkaline basalts.

\begin{tabular}{lllllll}
\hline & ${ }^{206} \mathrm{~Pb} /{ }^{204} \mathrm{~Pb}$ & $\pm 2 \sigma^{+}$ & ${ }^{207} \mathrm{~Pb} /{ }^{204} \mathrm{~Pb}$ & $\pm 2 \sigma^{+}$ & ${ }^{208} \mathrm{~Pb} /{ }^{204} \mathrm{~Pb}$ & 0.0326 \\
\hline TA 2012-27 & 19.575 & 0.0118 & 15.586 & 0.0111 & 39.088 & 0.0424 \\
TA 2012-31 & 19.551 & 0.0181 & 15.572 & 0.0156 & 39.045 & 39.139 \\
TA 2012-35 & 19.564 & 0.0258 & 15.599 & 0.0216 & 39.064 & 0.0574 \\
TA 2012-37 & 19.557 & 0.0093 & 15.578 & 0.0094 & 39.035 & 0.0288 \\
TA 2012-41 & 19.544 & 0.0262 & 15.569 & 0.0221 & 39.032 & 0.0582 \\
TA 2012-43 & 19.542 & 0.0135 & 15.568 & 0.0123 & 0.0134 & 38.994 \\
TA 2012-60 & 19.404 & 0.0144 & 15.581 & & 0.0375 \\
\hline
\end{tabular}




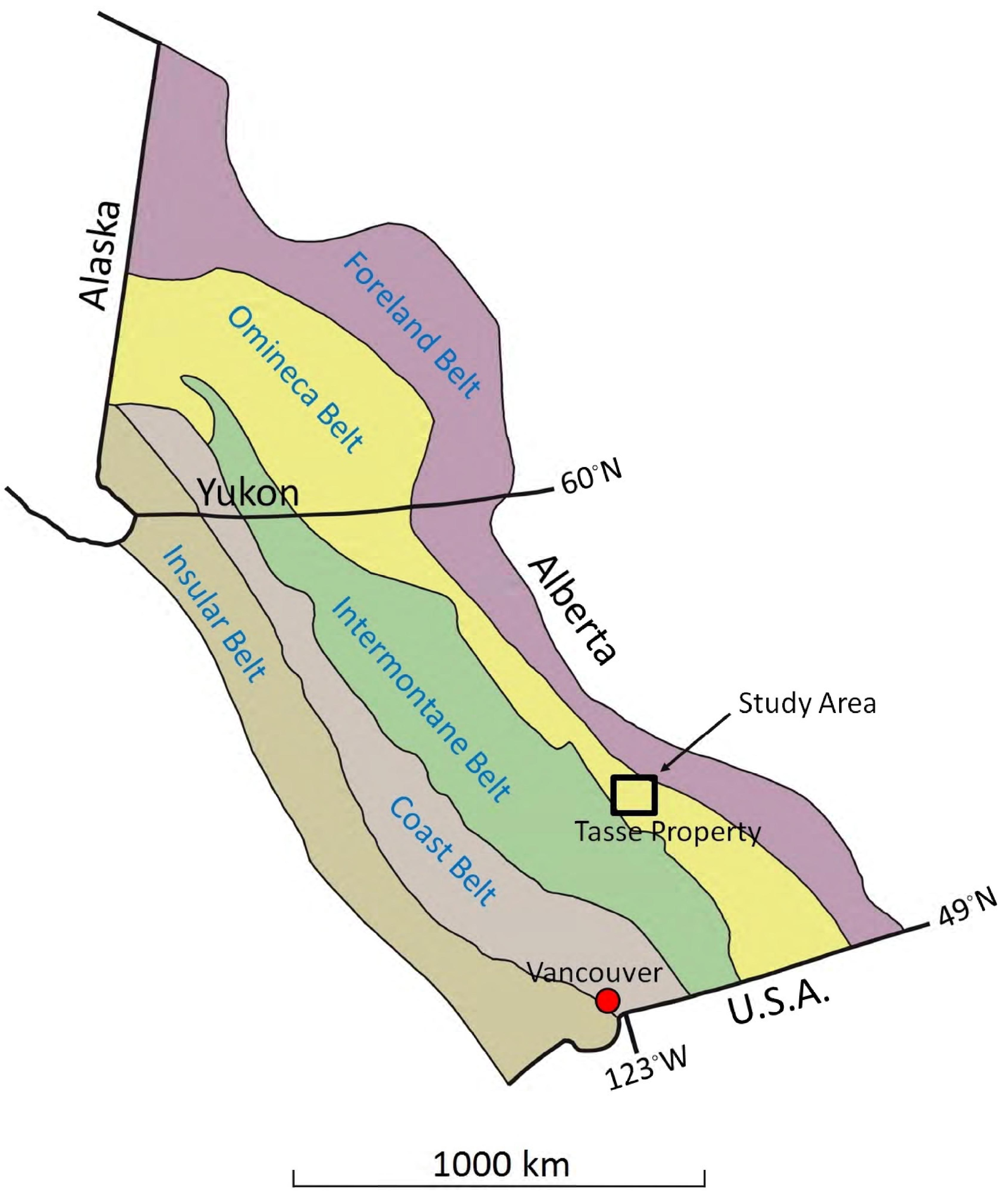

Supplementary Figure 1. A map of British Columbia and Yukon representing the five morphogeological belts. 
Supplementary Data Table 1. Field description and GPS coordinates of the Tasse mantle xenoliths.

\begin{tabular}{|c|c|c|c|c|c|}
\hline Sample \# & Rock Type & Eastings & Northings & Note & Tasse Property \# \\
\hline TA-2012-01 & Olivine-Pyroxene-Spinel Peridotite Xenolith & 628821 & 5827460 & Blasted Outcrop/Block & 5 \\
\hline TA-2012-02 & Olivine-Pyroxene-Spinel Peridotite Xenolith & 628823 & 5827469 & Blasted Outcrop/Block & 5 \\
\hline TA-2012-03 & Olivine-Pyroxene-Spinel Peridotite Xenolith & 628828 & 5827458 & Blasted Outcrop/Block & 5 \\
\hline TA-2012-04 & Olivine-Pyroxene-Spinel Peridotite Xenolith & 628812 & 5827480 & Blasted Outcrop/Block & 5 \\
\hline TA-2012-05 & Olivine-Pyroxene-Spinel Peridotite Xenolith & 628819 & 5827457 & Blasted Outcrop/Block & 5 \\
\hline TA-2012-06 & Olivine-Pyroxene-Spinel Peridotite Xenolith & 628822 & 5827463 & Blasted Outcrop/Block & 5 \\
\hline TA-2012-07 & Olivine-Pyroxene-Spinel Peridotite Xenolith & 628813 & 5827460 & Blasted Outcrop/Block & 5 \\
\hline TA-2012-08 & Spinel-bearing Dunite Xenolith & 628819 & 5827447 & Grains Collected from Broken Sample & 5 \\
\hline TA-2012-09 & Spinel-bearing Dunite Xenolith & 628820 & 5827447 & Blasted Outcrop/Block & 5 \\
\hline TA-2012-10 & Pyroxene-bearing Dunite Xenolith & 628820 & 5827447 & Blasted Outcrop/Block & 5 \\
\hline TA-2012-11 & Olivine-Pyroxene-Spinel Peridotite Xenolith & 628820 & 5827447 & Blasted Outcrop/Block & 5 \\
\hline TA-2012-13 & Olivine-Pyroxene-Spinel Peridotite Xenolith & 628833 & 5827461 & Blasted Outcrop/Block & 5 \\
\hline TA-2012-14 & Olivine-Pyroxene-Spinel Peridotite Xenolith & 628818 & 5827443 & Blasted Outcrop/Block & 5 \\
\hline TA-2012-15 & Olivine-Pyroxene-Spinel Peridotite Xenolith & 628790 & 5827432 & Blasted Outcrop/Block & 5 \\
\hline TA-2012-16 & Olivine-Pyroxene-Spinel Peridotite Xenolith & 628795 & 5827444 & Blasted Outcrop/Block & 5 \\
\hline TA-2012-17 & Olivine-Pyroxene-Spinel Peridotite Xenolith & 628791 & 5827449 & Blasted Outcrop/Block & 5 \\
\hline TA-2012-18 & Pyroxene- \& Spinel-bearing Dunite Xenolith & 628791 & 5827449 & Blasted Outcrop/Block & 5 \\
\hline TA-2012-19 & Olivine-Pyroxene-Spinel Peridotite Xenolith & 628787 & 5827443 & Blasted Outcrop/Block & 5 \\
\hline TA-2012-20 & Olivine-Pyroxene-Spinel Peridotite Xenolith & 628787 & 5827443 & Blasted Outcrop/Block & 5 \\
\hline TA-2012-21 & Olivine-Pyroxene-Spinel Peridotite or Pyroxenite Xenolith & 628788 & 5827431 & Blasted Outcrop/Block & 5 \\
\hline TA-2012-22 & Olivine-bearing Spinel Xenolith & 628770 & 5827424 & Blasted Outcrop/Block & 5 \\
\hline TA-2012-23 & Olivine-Pyroxene-Spinel Peridotite Xenolith & 628770 & 5827424 & Blasted Outcrop/Block & 5 \\
\hline TA-2012-24 & Olivine-Pyroxene-Spinel Peridotite Xenolith + Host Basalt & 628770 & 5827424 & Blasted Outcrop/Block & 5 \\
\hline TA-2012-25 & Spinel-bearing Dunite Xenolith & 628955 & 5827547 & Blasted Outcrop/Block & 5 \\
\hline TA-2012-44 & Dunite Xenolith & 628630 & 5826979 & Large Xenolith Pod $>30 \mathrm{~cm}$ & $5+$ \\
\hline TA-2012-45 & Dunite Xenolith & 628622 & 5826976 & Large Xenolith Pod $>25 \mathrm{~cm}$ & $5+$ \\
\hline TA-2012-46 & Dunite Xenolith & 628593 & 5826969 & Large Xenolith Pod $>25 \mathrm{~cm}$ & $5+$ \\
\hline TA-2012-48 & Dunite Xenolith & 628613 & 5826976 & Large Xenolith Pod $>20 \mathrm{~cm}$ & $5+$ \\
\hline TA-2012-49 & Dunite Xenolith & 628613 & 5826976 & Large Xenolith Pod $>20 \mathrm{~cm}$ & $5+$ \\
\hline TA-2012-55 & Olivine-Pyroxene-Spinel Peridotite Xenolith & 629565 & 5828132 & Collected from Anomaly 6 & 6 \\
\hline TA-2012-56 & Olivine-Pyroxene-Spinel Peridotite Xenolith & 629565 & 5828132 & Collected from Anomaly 6 & 6 \\
\hline TA-2012-62 & Olivine-Pyroxene-Spinel Peridotite Xenolith & 630012 & 5827612 & From a loose Boulder & 7 \\
\hline
\end{tabular}


Supplementary Table 2. Field description and GPS coordinates of the Tasse alkaline basalts

\begin{tabular}{|c|c|c|c|c|c|}
\hline Sample \# & Rock Type & Eastings & Northings & Note & Tasse Property \# \\
\hline TA-2012-26 & Host Rock - Vesicular Basalt & 622827 & 5827459 & Contains $\sim 7 \%$ Xenolith & 5 \\
\hline TA-2012-27 & Host Rock - Vesicular Basalt & 628831 & 5827448 & Contains $\sim 5 \%$ Xenolith & 5 \\
\hline TA-2012-28 & Host Rock - Vesicular Basalt & 628831 & 5827448 & Contains $\sim 5 \%$ Xenolith & 5 \\
\hline TA-2012-29 & Host Rock - Vesicular Basalt & 628832 & 5827449 & Contains $\sim 5 \%$ Xenolith & 5 \\
\hline TA-2012-30 & Host Rock - Vesicular Basalt & 628829 & 5827449 & Contains $4 \%$ to $6 \%$ Xenolith & 5 \\
\hline TA-2012-31 & Host Rock - Vesicular Basalt & 628829 & 5827447 & Contains $2 \%$ to $4 \%$ Xenolith & 5 \\
\hline TA-2012-32 & Host Rock - Vesicular Basalt & 628819 & 5827446 & Contains $2 \%$ to $4 \%$ Xenolith & 5 \\
\hline TA-2012-33 & Host Rock - Vesicular Basalt & 628815 & 5827446 & Contains $~ 5 \%$ Xenolith & 5 \\
\hline TA-2012-34 & Host Rock - Vesicular Basalt & 628823 & 5827440 & Contains $2 \%$ to $3 \%$ Xenolith & 5 \\
\hline TA-2012-35 & Host Rock - Vesicular Basalt & 628823 & 5827440 & Contains $4 \%$ to $6 \%$ Xenolith & 5 \\
\hline TA-2012-36 & Host Rock - Vesicular Basalt & 628823 & 5827440 & Contains $3 \%$ to $5 \%$ Xenolith & 5 \\
\hline TA-2012-37 & Host Rock - Vesicular Basalt & 628798 & 5827448 & Contains $2 \%$ to $3 \%$ Xenolith & 5 \\
\hline TA-2012-38 & Host Rock - Vesicular Basalt & 628894 & 5827442 & Contains $2 \%$ to $3 \%$ Xenolith & 5 \\
\hline TA-2012-39 & Host Rock - Vesicular Basalt & 628788 & 5827454 & Contains $2 \%$ to $3 \%$ Xenolith & 5 \\
\hline TA-2012-40 & Host Rock - Vesicular Basalt & 628788 & 5827449 & Contains $2 \%$ to $4 \%$ Xenolith & 5 \\
\hline TA-2012-41 & Host Rock - Vesicular Basalt & 628790 & 5827453 & Contains $3 \%$ to $5 \%$ Xenolith & 5 \\
\hline TA-2012-42 & Host Rock - Vesicular Basalt & 628628 & 5826974 & Contains $3 \%$ to $5 \%$ Xenolith & 5 \\
\hline TA-2012-43 & Host Rock - Vesicular Basalt & 628623 & 5826978 & Contains $1 \%$ to $2 \%$ Xenolith & 5 \\
\hline TA-2012-47 & Host Rock - Vesicular Basalt & 628623 & 5826978 & Contains $1 \%$ to $2 \%$ Xenolith & $5+$ \\
\hline TA-2012-50 & Host Rock - Vesicular Basalt & 625948 & 5828288 & Xenolith Free & 2 \\
\hline TA-2012-51 & Host Rock - Vesicular Basalt & 625948 & 5828288 & Xenolith Free & 2 \\
\hline TA-2012-52 & Host Rock - Vesicular Basalt & 625948 & 5828288 & Xenolith Free & 2 \\
\hline TA-2012-53 & Host Rock - Vesicular Basalt & 624577 & 5830355 & Contains $3 \%$ to $5 \%$ Xenolith & 1 \\
\hline TA-2012-54 & Host Rock - Vesicular Basalt & 624577 & 5830355 & Contains $2 \%$ to $3 \%$ Xenolith & 1 \\
\hline TA-2012-57 & Host Rock - Vesicular Basalt & 624577 & 5830355 & Contains $2 \%$ to $3 \%$ Xenolith & 1 \\
\hline TA-2012-58 & Host Rock - Vesicular Basalt & 624577 & 5830355 & Xenolith Free & 1 \\
\hline TA-2012-59 & Host Rock - Vesicular Basalt & 624577 & 5830355 & Xenolith Free & 1 \\
\hline TA-2012-60 & Host Rock - Vesicular Basalt & 624577 & 5830355 & Xenolith Free & 1 \\
\hline TA-2012-61 & Host Rock - Vesicular Basalt & 624577 & 5830355 & Xenolith Free & 1 \\
\hline
\end{tabular}

